\title{
AGE ASPECTS OF PROFESSIONAL DEVELOPMENT
}

Collective monograph

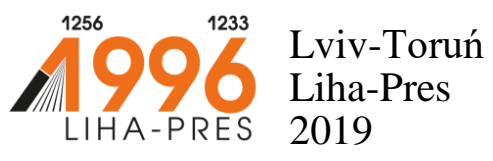




\section{Reviewers:}

Konrad Janowski, PhD, Vice-dean of the Faculty of Psychology, University of Economics and Human Sciences in Warsaw (Republic of Poland);

Prof. dr hab. Tadeusz, Dmochowski, University of Gdansk (Republic of Poland).

Age aspects of professional development : collective monograph / M. Smulson, O. Volobuieva, V. Hrishko-Dunaievska, H. Topolnytska, V. Demskyi, K. Oleksandrenko, H. Bahrii. - Lviv-Toruń : Liha-Pres, 2019. - 124 p.

ISBN 978-966-397-185-8

Liha-Pres is an international publishing house which belongs to the category "C" according to the classification of Research School for Socio-Economic and Natural Sciences of the Environment (SENSE) [isn: 3943, 1705, 1704, 1703, 1702, 1701; prefixMetCode: 978966397]. Official website www.sense.nl. 


\section{CONTENTS}

AGING AND SELF-DEVELOPMENT:

PSYCHOLOGICAL PROBLEMS

Maryna Smulson 1

LEADER'S ABILITY TO ENSURE THE ESSENTIAL MILITARY STUDY GROUP COHESION LEVEL

Olena Volobuieva 19

THE TEACHER'S EMOTIONAL COMPETENCE

IN SUBJECT-SUBJECT INTERACTION WITH FUTURE

OFFICERS-BORDER GUARDS IN FOREIGN LANGUAGE

LEARNING ENVIRONMENT

Valentyna Hrishko-Dunaievska

SOCIO-PSYCHOLOGICAL ANALYSIS OF CONTENT AND

STRUCTURE OF COMMUNICATIVE COMPETENCI ES OF

BORDERGUARD CADETS

Halyna Topolnytska 58

SOCIO-PSYCHOLOGICAL TRAINING AS AN EFFECTIVE

METHOD FOR FORMING COMMUNICATIVE SKILLS

OF BORDER GUARD CADETS

Valentyn Demskyi

THE ROLE AND PLACE OF FOREIGN LANGUAGE

COMMUNICATIVE COMPETENCE IN THE FORMATION

OF PROFESSIONAL COMMUNICATIVE ACTIVITY

Kateryna Oleksandrenko .90

PSYCHOLOGICAL PECULIARITIES OF FOREIGN LANGUAGE COMPETENCE FORMATION IN THE MONOLOGIC SPEECH OF FUTURE PHILOLOGISTS

Hanna Bahrii 102 


\section{AGING AND SELF-DEVELOPMENT: PSYCHOLOGICAL PROBLEMS}

\section{Maryna Smulson}

\section{INTRODUCTION}

Old age is a rather ambiguous period of life, which has not received enough attention in modern developmental psychology. It was not until the beginning of the 21 st century that society began to fight against ageism, that is, against prejudice against old age, rejection or neglect of the elderly. It is clear that this is due, first of all, to the apparent aging of humanity around the world, the steady increase in the number of older people in society.

For centuries, age distribution has looked like a pyramid, on top of which there are people that have reached old age. Now a sharp increase in life expectancy and a decline in fertility, especially in developed countries, have turned this pyramid into a mushroom with a massive hat. It is estimated that in 2060, the number of Americans over the age of 65 will double comparing to the current number - 92 million (20 percent). And nowadays, the most common diseases in the world are geriatric, namely, cardiovascular, cancer, diabetes and Alzheimer's disease.

Moreover, it is obvious that the boundary between adulthood and old age, and even between youth and old age is increasingly blurred and disappears, there is no specific moment of initiation from maturity to old age. In addition, today young people, and sometimes even the elderly, are actively involved in professional activities in many fields (economics, technology, culture, etc.). The retirement age is steadily rising, despite the protests of young people, sometimes quite active and rigid (France is a prime example). However, these protests are not related to the professional potential of the elderly, which almost no one questions, but to the struggles of young people for jobs. At the same time, employees often find it necessary to rely on the specialist's experience, which is related to his or her age and skills and wisdom acquired throughout life. On the other hand, such a situation certainly requires from an elderly professional constant selfdevelopment, professional and personal growth, which will block his / her lag from social and technological progress. This section is devoted to psychological problems of self-design and self-development.

\section{Specificity of self-development processes in old age}

There is a point of view that old age should not be treated as an age, but as an artificially constructed normative social project (design), that is, a set 
of conventional rules, laws, principles, norms, values, etc. This project defines not only the stereotyped attitude towards the elderly representatives of other generations, but also in many respects to the behaviour of the elderly themselves, their attitude towards themselves. The mechanisms of such construction, according to the sociologists M. Yeliutina and O. Smolkin include, first of all, an academic discourse (in particular, medical), which describes old age as a period of weakness, disability, survival, without defining the positive aspects of this period, secondly, the moral regulators that testify to the «elasticity» of the requirements for the treatment with elderly, and thirdly, the marker of intergenerational relations, highlighting the idea of present day old age as a model of one's own future old age. The following are some rather non-trivial mechanisms, such as the linguistic component, that is, the absence of positive semantic markers in terms related to aging, and, conversely, the presence of negative meanings (meaning, in general, opposition to the new-old) and the influence of the artistic discourse forming social expectations about the elderly. Finally, the modern «puerlistic» consciousness focuses public interest on the progress, change, «youth» of both people and ideas ${ }^{1,2}$.

From a psychological point of view, the most interesting point is the role of the elderly themselves in the design of such a project and the possibility of restructuring their attitude to themselves and their own problems of old age. In other words, it is about development and self-development in old age and their specificity.

Modern concepts of life-span development, that is, development that occurs throughout life, claim that any process of development is inherent in the internal dynamics of acquired and $\operatorname{lost}^{3,4,5,6,7}$. It is about life-long

1 Yeliutina M.E. (1999) Gerontologicheskoie napravleniie v strukture chelovecheskogo bytiia [Gerontological Direction in the Structure of Human Being] / M.E. Yeliutina. - Saratov : Izd. Sarat. gos. un-ta. - 139 p.

${ }^{2}$ Smolkin A.A. (2004) Sotsiokulturnaia dinamika otnosheniia k starosti [Sociocultural Dynamics of Attitude Towards Old Age]: dissertatsiia na soiskaniie uchenoi stepeni kandidata sociologicheskih nauk po specialnosti 22.00.04 : Sotsialnaia struktura, socialnyie instituty i processy [Social Structure, Social Institutions and Processes]/ A.A. Smolkin. - Saratov. - 144 p.

${ }^{3}$ Antsyferova L. I. (2006) Sposobnost lichnosti k preodoleniiu deformacii svoiego razvitiia [Person's Ability to Overcome Deformations of Their Development] / L. I. Antsyferova // Razvitiie lichnosti i problemy gerontopsihologii [Personality Development and Problems of Gerontopsychology]. - M.: Izd-vo „Institut psihologii RAN», - pp. 355-381.

${ }^{4}$ Baltes P. B. (2001) Vsevozrastnoj podhod v psihologii razvitiya: issledovanie dinamiki podemov i spadov na protyazhenii zhizni [An Age-Old Approach in Developmental Psychology: a Study of the Dynamics of Ups and Downs throughout Life] / P.B. Baltes // Psihologiya razvitiya : hrestomatiya [developmental psychology: anthology]. - SPb. : Piter. pp. 436-459.

${ }^{5}$ Maksymenko S.D. (2006) Geneza zdiisnennia osobystosti [Genesis of Special Features] / S. D. Maksymenko. - K. : Vydavnytstvo TOV «KMM». -240 p. 
development that never stops, even in death, which also determines a certain self-movement and self-development. The concept of non-linear development has emerged, according to which there is not only a lifelong potential growth, but there are downturns and plateaus, the amplification (enrichment) of certain functions and impoverishment of others, which also determines development. For example, it has been proven that intellectual development occurs throughout life and is multidimensional, but intellectual functioning changes - flowing operational-dynamic intelligence gradually transforms into crystallized domain-content. Operational-dynamic intelligence is associated with the basal organization of information processing and problem solving, and subject-content - with the functioning of operational-dynamic in the context of new knowledge and life situations ${ }^{8,9,10,11}$.

The task of development is significant in terms of the concept of continuous development. Development tasks include problems, demands and life situations that are generated by biological development, social expectations and human actions. These problems, as noted by experts, change in the course of life and provide direction, strength and fulfilment of development.

We associate development with changes in the mental model of the world, based on the concept of self-development (self-movement) of the personality of H. Kostiuk. Subjective self-development is seen as one in

\footnotetext{
${ }^{6}$ Smulson M.L. (2006) Smysl zhizni v mentalnoj modeli mira [Sense of Life in the Mental Model of the World] / M.L. Smulson // Psihologicheskiie problemy smysla zhizni i akme [Psychological Problems of Life Meaning and Acme]: materialy X simpoziuma / Pod red. G.A. Vaizer, E.E. Vahromova. - M. - pp. 28-29.

${ }^{7}$ Smulson M.L. (19-20 kvitnia 2010 roku) Kontseptsiia samorozvytku osobystosti H.S. Kostiuka i nagalni vyklyky siogodennia [The Concept of H.S. Kostiuk's Personality SelfDevelopment and Today's Urgent Challenges] / M.L. Smulson // Materialy II Vseukraiinskoho psihologichnoho konhresu, prisviachenogo 110 richnytsi vid dnia narodzhennia H.S. Kostiuka. Tom II. - K. : DP «Informatsiino-analitychne ahenstvo».

${ }^{8}$ Baltes P. B. (2001) Vsevozrastnoj podhod v psihologii razvitiya: issledovanie dinamiki podemov i spadov na protyazhenii zhizni [An Age-Old Approach in Developmental Psychology: a Study of the Dynamics of Ups and Downs throughout Life] / P.B. Baltes // Psihologiya razvitiya : hrestomatiya [developmental psychology: anthology]. - SPb. : Piter. pp. 436-459.

9 Smulson M.L. (2003) Psyholohiia rozvytku intelektu [Psychology of Intellectual Development] /M.L.Smulson - K.: Nora-druk. - 298 p.

${ }^{10}$ Smulson M.L. (2009) Intelekt i mentalni modeli svitu [Intelligence and Mental Models of the World] / M.L.Smulson // Naukovi zapysky. Seriia «Psihologiia i pedagogika». Tematichnyi vypusk «Suchasni doslidzhennia kognityvnoii psihologii» [Contemporary Studies in Cognitive Psychology] - Ostrog: Vid-vo Natsionalnogo universytetu «Ostrog». - Vip. 12. - pp. 38 - 49.

${ }^{11}$ Horn J.L. (1989) The Theory of Fluid and Crystailized Intelligence in Relations to Concepts of Cognitive Psychology and Aging in Adulthood / J.L. Horn // Aging and cognitive processes / Ed. by F.I.M. Craik, S. Trehuh. - New York : Plenu. - P. 76-112.
} 
which the subject sets his or her own goal of development, and uses various opportunities and potential to achieve it - both his own personal and that of the external environment. We associate self-development with the emerging of new formations; we interpret self-development as a change in the mental model of the world, or the system of mental models (mentality); and also as a new meaning; as a reinterpretation of personal experience. Selfdevelopment is determined by restructuring, amplification, reinterpretation, reconstruction of mental models of the world, restructuring of connections between them at all levels in the metamental model (i.e., the system model that defines personality) ${ }^{12,13,14}$.

However, is there any difference between the development of old age and development in other periods of life? We believe that the challenges of old age development are specific and, above all, related to the complex relationship between old age and the future.

The complex relationships of the old person with the past events influence their perception of the future events, moreover, even predetermine this perception. In this connection, experts refer to the philosophical characterization of Martin Heidegger's future (in Genesis and Time, 1923). According to Heidegger, the future not only comes to us, but rather we go to it with our expectations. Since these expectations are generated in the process of interpreting the past by us, the future should be understood as a continuation of the past. What is contemporary, then? The Continuous Process of Transformation of the Past into the Future» ${ }^{15}$.

Recall that Hoift et $\mathrm{al}^{16}$ distinguish between the immediate, near and distant future in the context of analysis of old age and aging.

The immediate future is a continuation of the present, and this connection is fundamental to the continuity of time. From the point of view of present time it is not perceived as an independent temporal level. The immediate future is reflected now, in particular, it is in line with the concept

${ }^{12}$ Kostiuk H.S. (1969) Princip razvitiia v psihologii [The Principle of Development in Psychology] / H.S. Kostiuk // Metodologicheskiie i teoreticheskiie problemy psihologii [Methodological and Theoretical Problems of Psychology]. - M.: Nauka. - pp. 118-152.

${ }^{13}$ Maksymenko S.D. (2006) Geneza zdiisnennia osobystosti [Genesis of Special Features] /

S. D. Maksymenko. - K. : Vydavnytstvo TOV «KMM». -240 p.

${ }^{14}$ Smulson M.L. (19-20 kvitnia 2010 roku) Kontseptsiia samorozvytku osobystosti H.S. Kostiuka i nagalni vyklyky siogodennia [The Concept of H.S. Kostiuk's Personality SelfDevelopment and Today's Urgent Challenges] / M.L. Smulson // Materialy II Vseukraiinskoho psihologichnoho konhresu, prisviachenogo 110 richnytsi vid dnia narodzhennia H.S. Kostiuka. Tom II. - K. : DP «Informatsiino-analitychne ahenstvo».

${ }^{15}$ Hoift G. (2003) Gerontopsihosomatika i vozrastnaia psihoterapiia [Gerontopsysomatics and Age-Related Psychotherapy] / G. Hojft, A. Kruze, G. Radebold. - M. : ACADEMIA (Izdatelskij Centr «Akademiia»). - 370 p., p.84.

${ }^{16}$ Ibid. 
of anticipatory reflection of P. Anokhin and M. Bernstein. The perception of the immediate future is the least painful for the elderly, it is so close and integrated with the present that the old person does not distinguish his perception and experience into a separate problem. This provides the continuity of time, even at a very old, advanced age, unless, of course, deep dementia is present.

The near future is interpreted as an area of the future that is linked to specific aspirations, plans, intentions, expectations, hopes, fears, etc. The near future is presented to us as an independent temporal level, and we are consciously preparing for it. The preparation and emotional experiences of expectations, hopes, fears, etc. separate the near future from the present, but the time span of the near future is not defined, it may be different - from days to years.

The attitude of the person to his/ her future is analysed according to his/ her time frames, confidence in the possibility of changing the situation, as well as the so-called density, for which there are large individual differences. Numerous plans and intentions testify to a constructive attitude towards one's future that mobilizes creativity. The other extreme, when there are almost no plans and intentions, when the future is perceived as somewhat amorphous, one that is not exposed, is presented as a frightening void which is a pathological relation to the future. It is shown that such perception of the future is characteristic of people (not only the elderly) who have lost their jobs for a long time, suffered other heavy losses and cannot act on their own.

It is crucial to make a conscious distinction between the immediate and the near future. As to the immediate future, one can recall Albert Einstein's famous ironic statement, «I never worry about the future, because it comes too fast». Therefore, the immediate future is sometimes figuratively called «the present that is ongoing.» Attempts to delay the «moment», to perceive the future as the present, which is ongoing, are also characteristic not only of the elderly, but also of certain neurotic states in many age categories. On the other hand, as Jonathan Swift very nicely put it: «The future never just happened. It was created».

Non-specific plans, which are expressed by the words «ever», are associated with the distant future. Attitudes towards the distant future may also be different. At any age, you may think that there is no «future», that the situation will not change, similar to a non-constructive attitude towards the near future. It is clear that such an opinion will not surprise the old man, but it is necessary to be sensitive to new stimuli both in the present and in the future.

The main tasks of development in old age are the successful overcoming of the crisis of old age, the victory over tanatophobia, dementia processes and more. It is shown that the optimum type of aging implies personal self- 
determination in old age in the unity of processes of self-development and self-realization ${ }^{17,18}$. Successful resolution of the crisis of old age implies personal development (self-development) in the direction of deepening of understanding of the world, wisdom, comprehension of the lived and experienced during life ${ }^{19,20,21,22}$. The lack of readiness for such changes in life position and values, for the transformation of the mental model, indicates an unprecedented crisis of meeting old age, and the increase in rigidity, in turn, leads to dementia. Therefore, the transformation (reinterpretation) of the mental model by a person who perceives his own old age as an unconditionally problematic, painful place should be a fundamental goal of working on the psychological support of the elderly.

However, the problems of development in old age are determined and solved mainly independently, they are fundamentally individualized, closely related to the attitude of a particular elderly person to all levels of the future described above, with an understanding of their place and significance in their own lives, taking into account their age, health condition, marital status, professional achievements, etc. Therefore, it can be stated that the mechanism of development in old age is «independent self-design» (although this phrase looks like a certain tautology). This means that selfdesign in old age, as a rule, has no analogues. It is unclear, "what life guidelines to choose», as it is mostly clear when it comes to self-design at other age levels, when development occurs in certain socially organized conditions (e.g., training, education, socially useful work). Attempts to

${ }^{17}$ Havrilina L. K. (2010) Krizisy vzrosloi zhizni: momenty rosta [Adult Life Crises: Moments of Growth] / L.K. Havrilina, V.M. Byzova. - Spb. : Rech [Speech]. - 221 p.

${ }^{18}$ Yermolaieva M.V. (2008) K voprosu o potentsialah razvitiia lichnosti v starosti [On the Issue of Personality Development Potentials in Old Age] / M.V. Yermolaieva, S.B. Priahina // Mir psihologii [World of psychology]. - №2. - pp. 244-255.

${ }^{19}$ Yermolaieva M.V. (2008) K voprosu o potentsialah razvitiia lichnosti v starosti [On the Issue of Personality Development Potentials in Old Age] / M.V. Yermolaieva, S.B. Priahina // Mir psihologii [World of psychology]. - №2. - pp. 244-255.

${ }^{20}$ Smulson M.L. (2006) Smysl zhizni v mentalnoj modeli mira [Sense of Life in the Mental Model of the World] / M.L. Smulson // Psihologicheskiie problemy smysla zhizni i akme [Psychological Problems of Life Meaning and Acme]: materialy X simpoziuma / Pod red. G.A. Vaizer, E.E. Vahromova. - M. - pp. 28-29.

${ }^{21}$ Smulson M.L. (19-20 kvitnia 2010 roku) Kontseptsiia samorozvytku osobystosti H.S. Kostiuka i nagalni vyklyky siogodennia [The Concept of H.S. Kostiuk's Personality SelfDevelopment and Today's Urgent Challenges] / M.L. Smulson // Materialy II Vseukraiinskoho psihologichnoho konhresu, prisviachenogo 110 richnytsi vid dnia narodzhennia H.S. Kostiuka. Tom II. - K. : DP «Informatsiino-analitychne ahenstvo»

${ }^{22}$ Rozuminnia ta interpretatsiia zhittievogo dosvidu yak chynnyk rozvytku osobystosti : monografiia [Understanding and Interpretation of Life Experience as a Factor of Personal Development : a Monograph] (2013) / za red. N.V.Chepelievoii. - Kirovograd : Imeks-LTD. $276 \mathrm{p}$. 
«return» from old age to younger age levels are not only impossible, but also harmful and risky (the life-threatening status of «young old» is known). On the other hand, to yield to old age, to surrender «at its mercy» and not to set the tasks of development is also extremely harmful, fraught with stagnation, «malignant» tanatophobia, dementia, etc. At the same time, defining the tasks of development implies understanding of the future as new, designed and created, rather than «current present».

Hence, there is the general specificity of development in old age, which fundamentally acts as self-development and requires special selfimprovement - from the intellectual to the physical - which we propose to call «the activity of self-development». At the same time, the transformations obtained are neither a direct product of another activity (as in a learning activity), nor a by-product (such as in work, cognitive, project, etc.). The regression of certain functions, their restructuring (not always amplified) also acts as a development. And as a result, the old person, constantly self-improving, adapts to the other self, receives a different structure of memory, attention, finally, general intelligence, and, most importantly, transformed and more adequate mental model of the world. Therefore, self-development activity is a separate, specifically organized activity, which we propose to consider as a leading activity in old age.

Development in old age, like any development, contributes to the emergence of new mental formations. Our theoretical and experimental studies show that such new mental formations include, first of all, the reflection of one's own problems brought by old age, the renewed (wise, integrative, restructured) mental model of the world, the realization of appropriate conscious choices, self-regulation and counteracting dementia, so called «overlapping» by their general intelligence, overcoming tanatophobic experiences. All these new mental formations, in turn, have the opposite positive effect on the development of the elderly. Thus, the studies conducted under our supervision have shown convincingly how much oldage development inhibits tanatophobic experiences, and what bright colours the life of an elderly person blossoms into as he directs the psychic energy that goes to fight the fear of death, to productive self-development activities $^{23,24}$.

${ }^{23}$ Berezina O. O. (2011) Doslidzhennia psihologichnyh osoblyvostei osib litniogo i pohylogo viku [Research of Psychological Characteristics of Elderly and Old People] / O. O. Berezina // Aktualni problemy psyhologii [Actual Problems of Psychology] : Zbirnyk naukovyh prats Instytutu psyhologii imeni H.S. Kostiuka NAPN Ukrainy / Za red. S. D. Maksymenka. - T. XIII. - Ch. I. - K. - pp. 49-58.

${ }^{24}$ Kovalenko-Kobylianska I.H. (2011) Spetsyfika nadannia psyhologichnoii dopomogy z urahuvanniam osoblyvostei pizniogo herontogenezu [The Specificity of Providing 
Another equally important goal of self-development in old age is to fight dementia. It is clear that dementia is a physiological process, and Alzheimer's disease is one of the worst manifestations here. Today, however, there is a psychologically attractive so-called existential view, according to which the psyche in old age is destroyed not only by an inverted process in the brain (in this case, according to M. Semkova, defeat of the patient and the one trying to help him should be recognized). This destruction, on the contrary, is acknowledged, at least in part, by the effects of gross, irrational psychological protections, and therefore it is hoped to influence the process in some way ${ }^{25}$.

Let us dwell in more detail on the relevant argumentation offered by the cited author. Yes, it is known that mental disorders in old age have clear, peculiar symptoms, which are not characteristic of other disorders of the psyche against the background of organic brain damage. Similar symptoms are memory impairment, acuteness, rapid mental fatigue. Depression can occur, especially if people are aware of the extent to which the disease has limited their ability.

However, the old people are characterized by such unusual for pure organic phenomena as anxiety, loss of orientation in time, a kind of delusional type of confidence that someone intentionally harms them or steals, threatens and so on. The reason for this is that the threat of extinction mobilizes the most powerful psychological protection that do not allow the thoughts of death to reach consciousness, even at the cost of psychic destruction.

In addition, according to some authors, old age with its loss (loved ones, health, working capacity, social status, etc.) should be considered as traumatic stress of extreme force and, accordingly, old age as post-traumatic stress. However, at the same time M. Siemkova describes features of the mental model of the subject, which contribute to the fundamental deterioration of mental health in old age. It was found out that all people under her investigation were strongly afraid of old age and death, had a developed sense of obligation, and perceived life as a rigorous obligation, were committed to professional achievement and / or family well-being, and at the same time, had little initiative. In addition, their emotional, close relationships were limited to the family, and any setbacks were seen as

Psychological Assistance, Taking into Account the Features of Late Gerontogenesis] [Elektronnyi resurs] / I.G. Kovalenko-Kobylianska // Tehnologii rozvytku intelektu [Intelligence Development Technologies]. T. 1, № 2 Retrieved from www.psytir.org.ua/ index.php./technology_intellect_develop/ article/view/43.

${ }_{25}$ Siemkova M.P. (2008) Neprozhitaia starost [Unwell old age] [Elektronnij resurs] / M.P.Siemkova // Retrieved from www.samlib/ru/s/semkowa_m_p /neprozhitayastarostx. Shtml 
catastrophes and needed support. For such individuals, the weak point is the conflict in the area of freedom / dependence and autonomy / subordination. Interestingly, these traits often lead to neuroses and depression of younger people. Therefore, as we can see, according to the approach described above, we can make a certain prediction of the old man's predisposition to dementia.

\section{Intellect and Wisdom in Old Age}

We have already noted that intellectual processes, in particular, flowing and crystallized intelligence undergo significant changes in old age. There are also certain special cognitive (intellectual) signs that indicate dementia potential. Cognitive impairment common to dementia affects more than one area of cognitive functioning. Alistair Burns and Tony Hope note in the book, «Old Age Psychiatry» (Old Age Psychiatry, 2003) that memory and at least one of such cognitive functions as speech and constructive ability, thinking, reasoning are most commonly impaired.

As to memory, the most striking aspects of dementia are the deliberate reproduction (remembering) of new information and prospective memory (remembering that something needs to be done in response to a specific hint: such as, to turn off the light before leaving home). Memory of recent events is affected by dementia more than distant ones ${ }^{26,27}$. People with dementia have impaired discursive, that is, narrative, abilities ${ }^{28}$.

Neuropsychological studies of normal aging, performed at the school of O. Luria, indicate that the leading age-related symptom of normal aging is a slowdown in activity (latency), especially at the stage of its initiation ${ }^{29,30}$. The latter is most evident when retrieving information from storage systems. Later, the possibilities of simultaneous multichannel concurrent performance

${ }^{26}$ Huppert F.A. (1994) Memory Function in Dementia and Normal Aging - dimension or dichotomy? / F.A.Huppert // Dementia and Normal Aging / Ed. by F.A. Huppert, C. Brayne, D.W. O'Conner. - Cambridge : Cambridge University Press. - P. 291-330.

${ }^{27}$ Huppert F.A. (1994) What Is the Relationship between Dementia and Normal Aging? / F.A. Huppert, C. Brayne // Dementia and normal ageing / Ed. by F.A. Huppert, C. Brayne, D.W. O'Conner. - Cambridge : Cambridge University Press. - P. 3-11.

28 Kempler D. (1994) Language in Dementia and Normal Ageing/ D. Kempler, E.M. Zelinski // Dementia and normal ageing / Ed. by F.A. Huppert, C. Brayne, D.W. O’Conner. - Cambridge : Cambridge University Press. - P. 331-365.

${ }^{29}$ Korsakova N. K. (1996) Neiropsihologiia pozdnego vozrasta: obosnovaniie kontseptsii i prikladnyie aspekty [Late Age Neuropsychology: Concept and Applied Aspects Ground] // Vestn. Mosk. un-ta. - Ser. 14. Psihologiia. - № 2. - pp. 32-37.

30 Roshchina I.F. (2015) Issledovanie normalnogo i patologicheskogo stareniia (neiropsihologicheskii podhod) // Medicinskaia psihologiia v Rossii [The Study of Normal and Pathological Aging (Neuropsychological Approach) // Medical Psychology in Russia]: elektron. nauch. zhurn. - N 2(31) [Elektronnyj resurs]. - Retrieved from: http://mprj.ru 
of various actions, i.e. difficulties of switching and distribution of attention, come to a limit. There is a limitation in the flow of memory, reducing its resistance to distractions. These cognitive limitations are thought to be related to the functional deficits of the first brain block, as the overall background components of activity change: the energy supply of mental activity decreases, the inhibition processes predominate.

The second component of normal aging is due to limitations in the processing of spatial information characteristics. Relevant data indicate a decrease in the right hemisphere's involvement in cognitive processes. Again, problems arise with parallel multichannel processing of information, since the time-integrated function is based on the principle of simultaneity inherent in the right hemisphere ${ }^{31}$.

The school of $\mathrm{O}$. Luriia basically distinguishes three variants of normal aging. The first is based on a decrease in the level of energy support for the activity already discussed above. Its characteristic manifestations are a rather long latency when engaging in the activity, a relatively small period of its effective implementation, followed by exhaustion and incompleteness of actions, as well as one-channel processing of information. The prerequisites for preserved mental functioning are the preservation of criticality, the regulative role of speech, the existence of strategies that ensure the distribution of activity in time and internal space. Therefore, in this variant of normal aging self-design should be aimed directly at amplification - the development of these preconditions. Let us highlight again that this is the persistence of criticality, the regulatory role of conceptual thinking, the development of specific strategies for distributed activity.

The second variant of normal aging, as noted above, is related to the lack of simultaneity in the processing of first-party information in the visualspatial sphere. This variant of aging can be considered as the most favourable, especially with the purposeful use of the strategy of grinding the procedures of the problem solution, «transfer of actions to the level of the extensive, step-by-step, consistent, controlled execution $»^{32}$, i.e. performing of actions without so-called automatisms. Special work on self-design and

31 Roshchina I.F. (2015) Issledovanie normalnogo i patologicheskogo stareniia (neiropsihologicheskii podhod) // Medicinskaia psihologiia v Rossii [The Study of Normal and Pathological Aging (Neuropsychological Approach) // Medical Psychology in Russia]: elektron. nauch. zhurn. - N 2(31) [Elektronnyj resurs]. - Retrieved from: http://mprj.ru

32 Roshchina I.F. (2015) Issledovanie normalnogo i patologicheskogo stareniia (neiropsihologicheskii podhod) // Medicinskaia psihologiia v Rossii [The Study of Normal and Pathological Aging (Neuropsychological Approach) // Medical Psychology in Russia]: elektron. nauch. zhurn. - N 2(31) [Elektronnyj resurs]. - Retrieved from: http://mprj.ru 
self-development towards mastering such a strategy can have a positive effect on the lack of simultaneity.

However, it is known that abrupt changes in the space of life (in the broad sense of the word) can lead to decompensation, such as a change of residence or linguistic environment. Therefore, preparation for such a change requires special work on appropriate self-design and further selfdevelopment, as well as general amplification requests for development in all areas where there is potential for decompensation.

The third variant of aging is characterized by a decrease in the arbitrary regulation of activity in the aspect of predicting the result and building adequate programs. This refers to impulsive decision-making, inadequate assessment of one's own capabilities, which, while maintaining cognitive criticality, can lead to decompensation, failure experiences, etc.

It is obvious that adequate design and self-design of the activity outcome, which underpins its prognosis, are required in this case.

If it has been a matter of normal aging variants so far, which, on the assumption of self-design and self-development task awareness, could be compensated, then the fourth variant of aging is dangerous in terms of decompensation. It combines two dangerous factors: energy support for the activity and its arbitrary regulation. In this case the insufficient spontaneity, sphere of interest narrowing, emotional monotony and increased forgetfulness occur. Somatic diseases and deprivation of communication contribute to the transformation of this variant of aging into dementia ${ }^{33}$.

Consideration should also be given to the specificity of the amplification of mental development at this age. The amplification of mental development is generally regarded as the maximum use of opportunities of every age for healthy mental development. O. V. Zaporozhets opposed the amplification to the artificial acceleration of the child development, which is accompanied by the simplification of development, that is, its stripping and impoverishing ${ }^{34}$. Currently, the concept of amplification has been the most developed for the preschool childhood, but we believe that it can be used for all ages including the elderly one. Moreover, if «co-operation» of the acceleration and amplification processes can be assumed for some other aging periods, the acceleration of the elderly mental development is impossible in the conditions of limited life resource.

Therefore, we can only speak of certain amplification, enrichment of mental development in old age, such as training and replacement of

${ }^{33}$ Ibid.

${ }^{34}$ Zaporozhets A.V. (1986) Izbrannyie psihologicheskiie trudy [Selected Psychological Works] / A.V. Zaporozhets - V dvuh tomah. - T.1. Psihicheskoie razvitiie rebenka [Child's Mental Development]. - M.: Pedagogika. -320 p. 
weakened mental functions (such as memory), compensation and «overlapping» them with other functions of general intelligence. Conscious self-development of personality in old age involves independent decisionmaking about the directions of such amplification based on understanding one's own involutional deficits or regression. It follows therefrom that selfdevelopment and self-design in old age do not exclude the understanding of the age deficiency existence. It famously accompanies normal aging, and its consideration and awareness largely determine the specific features of intellectual problems in old age.

As noted above, one of the components of cognitive aging is the change in the vector of brain hemisphere activity toward the dominance of the left hemisphere. In this aspect, neuropsychological studies are convincingly confirmed by psychological researches of conceptual thinking in the elderly, conducted under the guidance of M. O. Kholodnaia ${ }^{35}$.

In her opinion, they are precisely the later stages of ontogenesis when certain effects are most clearly manifested, which generally characterize the mechanisms of functioning intelligence. This is, in particular, the heterogeneous and compensatory nature of intellectual activity. Experimental studies conducted under her leadership confirm the major results, according to which a discernable decrease in old age indicates fluid intelligence. Indicators of crystallized intelligence, in particular verballogical function, are the most retained.

A comparative study of the college students' and the elderly's intelligence shows, in particular, that the latter have the same indicators as the students have at the factor of «verbal understanding» (crystallized intelligence) and significantly lower indicators at the factors of «spatial organization» and «memory / attention concentration» (Fluid intelligence). At the same time, the study of cognitive styles revealed that the older people are much more dependent and rigid than the young people, that is, demonstrate the rigidity of the intellectual system. This suggests that in the context of increasing involutional deficits, conceptual thinking unmediatedly regulates the intellectual activity of an old man, acting as a compensatory resource $^{36}$.

${ }^{35}$ Kholodnaia M.A. (2012) Psiholohiia poniatiinogo myshleniia: Ot kontseptualnyh struktur k poniatiinym sposobnostiam [The Psychology of Conceptual Thinking: From Conceptual Structures to Conceptual Abilities] / M.A.Kholodnaia - M.: Izd-vo «Institut psihologii RAN». $288 \mathrm{p}$.

${ }^{36}$ Kholodnaia M.A. (2012) Psiholohiia poniatiinogo myshleniia: Ot kontseptualnyh struktur k poniatiinym sposobnostiam [The Psychology of Conceptual Thinking: From Conceptual Structures to Conceptual Abilities] / M.A.Kholodnaia - M.: Izd-vo «Institut psihologii RAN». $288 \mathrm{p}$. 
Therefore, in the neuropsychological and psychological studies analyzed above, the compensatory capacity and functional retention of the left hemisphere, that is, conceptual thinking, are considered as a protector factor against the feasible development of dementia processes in normal aging. Conceptual thinking activates sound defense mechanisms, enabling the mental model's transformation. On the other hand, training cognitive and metacognitive components of intelligence is of fundamental importance. Due to the fact, E. Goldberg offers some indirect approaches to the development of flexibility and transformation of the mental model through the influence on metacognitive functions, i.e. on the intellect (it is not about a certain mental skill, but about organizing them all). These include the systematic creation of tools, the creation of images of the future, language as metacognition (providing the means of models' creation, and management functions - the means of models' manipulation and carrying out operations on them), as well as goal-setting and self-awareness ${ }^{37,38}$.

Under this approach, it is almost irrelevant what old people remember. What is important, on the contrary, is how they conceive, understand, interpret, and reinterpret their own experience, both old and new, fresh. Flexible mental models are considered to be such interpretative schemes. They are formed over a lifetime and are the basis of pattern recognition (it is the ability to recognize a new object or new problem as an element of a familiar class of objects or problems).

According to E. Goldberg, they are the basis of the wisdom of the elderly, which he defines as «the ability to combine the new with the old, to use the old experience to solve a new problem ${ }^{39}$. Wisdom is the highest level of competence, that is, the special ability to recognize similar elements between new and previously solved tasks. The latter presupposes that a competent (wise) person has a large set of mental images, each of which captures the essence of a wide range of specific situations and the most effective actions related to these situations. Nonetheless, the source of wisdom is not only the individual's own wisdom. The origin of wisdom (as well as mentality) is a culture that represents the collective wisdom of society, as well as the wisdom of class, species, and group. Only after

${ }^{37}$ Goldberg E. (2003) Upravliaiushchii mozg: lobnyie doli, liderstvo i civilizatsiia [The Governing Brain: Frontal Lobes, Leadership and Civilization] / E. Goldberg. - M. : Smysl. $335 \mathrm{p}$.

${ }^{38}$ Goldberg E. (2007) Paradoks mudrosti [The Paradox of Wisdom] / E.Goldberg. - M. : Pokolenie. $-384 \mathrm{p}$.

${ }^{39}$ Goldberg E. (2007) Paradoks mudrosti [The Paradox of Wisdom] / E.Goldberg. - M. : Pokolenie. -384 p. 
coming to grips with the above types of wisdom, one may talk of the individual's wisdom ${ }^{40}$.

Competence and wisdom, according to E. Goldberg, is not only an advanced ability to penetrate into the essence of things, but also an understanding of what action must be taken to change them. Therefore, both wisdom and competence are valued for their prescriptive capacity.

The majority of people associate wisdom with old age. J. Heckhausen, R.Dixon, and P. Bolts made a survey concerning the properties the experiment participants acquire at different ages. Virtually everyone reckoned that wisdom became the dominant attribute of people after they were fifty years old. In terms of desirability, wisdom was also among the most desirable traits. M. Perlmater and colleagues have also found that most people consider wisdom a desirable property ${ }^{41}$. It turns out, as E. Goldberg rightly points out, «if people believe that wisdom is the reward of old age, and they also see wisdom as one of their most desirable traits, then they should also believe that aging has its benefits, its positive side and its unique and valuable assets» ${ }^{42}$.

\section{CONCLUSIONS}

The basic directions of normal aging, the psychological support of which is connected with the amplified development of certain specific intellectual and activity components in old age have been shown above. Selfdevelopment and self-design should be aimed at the overall reinterpretation of the mental model in old age, which is required to achieve mental wellbeing at this age. In doing so, one should take into account the peculiarities of the subject's mental model, which lead to a fundamental mental health deterioration in old age. It is obvious for the elderly that the mental development acceleration tends to be unacceptable and impossible in view of limited life resources. Therefore, we may only speak of certain amplification, enrichment of mental development in old age. Conscious selfdesign and self-development of an individual in old age implies independent decision-making concerning the directions of such amplification based on understanding their own involutional deficits. This requires relevant intellectual support at the level of conceptual thinking, that is, reflected intellectual actions.

\footnotetext{
${ }^{40}$ Ibid.

${ }^{41}$ Ibid.

${ }^{42}$ Goldberg E. (2007) Paradoks mudrosti [The Paradox of Wisdom] / E.Goldberg. - M. : Pokolenie. -384 p.
} 


\section{SUMMARY}

Old age is a specific age period, sometimes regarded as a «social project». The role, played by the elderly in designing such a project as well as restructuring their attitude to themselves and their own old age problems, is crucial. The main tasks of development in old age are the successful overcoming of an old age crisis, conquering tanatophobia, dementia processes and more. Development in old age acts as self-development. Selfdevelopment activity (work) is a particular, specifically organized activity, which we consider as a leading activity in old age.

It may well be argued that the updated (wise, integrative, restructured) mental model of the world, reflection of one's own problems brought by old age, realization of relevant conscious choices, self-regulation and opposition to demental processes, the so-called «overlapping» by their general intelligence, overcoming tanatophobic experiences should be distinguished among the newly formed structures. The key point in the fight against dementia is, first, the mental model's transformation, and second, the cognitive and metacognitive intelligence components training.

Successful tackling old age crisis implies personal development (selfdevelopment) in the direction of advanced understanding of the world, wisdom, sense of life and survivorship in the course of a lifetime. The lack of readiness for such changes in view and values of life, the transformation of the mental model bears testimony to an unconquerable old age related crisis while the increase in rigidity, in its turn, leads to dementia. The leading psychological conditions for the transformation of mental models include the process link with intellectual changes and enrichment of intelligence, with the reflection and the interpretative (narrative) potential of the subject, on the one hand, and the subject's readiness for self-development, on the other.

\section{REFERENCES}

1. Antsyferova L. I. (2006) Sposobnost lichnosti k preodoleniiu deformacii svoiego razvitiia [Person's Ability to Overcome Deformations of Their Development] / L. I. Antsyferova // Razvitiie lichnosti i problemy gerontopsihologii [Personality Development and Problems of Gerontopsychology]. - M.: Izd-vo „Institut psihologii RAN», - pp. 355381. [in Russian]

2. Baltes P. B. (2001) Vsevozrastnoj podhod v psihologii razvitiya: issledovanie dinamiki podemov i spadov na protyazhenii zhizni [An AgeOld Approach in Developmental Psychology: a Study of the Dynamics of Ups and Downs throughout Life] / P.B. Baltes // Psihologiya razvitiya : hrestomatiya [developmental psychology: anthology]. - SPb. : Piter. pp. 436-459. [in Russian]

3. Berezina O. O. (2011) Doslidzhennia psihologichnyh osoblyvostei osib litniogo i pohylogo viku [Research of Psychological Characteristics of 
Elderly and Old People] / O. O. Berezina // Aktualni problemy psyhologii [Actual Problems of Psychology] : Zbirnyk naukovyh prats Instytutu psyhologii imeni H.S. Kostiuka NAPN Ukrainy / $\mathrm{Za}$ red. S. D. Maksymenka. - T. XIII. - Ch. I. - K. - pp. 49-58. [in Ukrainian]

4. Havrilina L. K. (2010) Krizisy vzrosloi zhizni: momenty rosta [Adult Life Crises: Moments of Growth] / L.K. Havrilina, V.M. Byzova. - Spb. : Rech [Speech]. - 221 p. [in Russian]

5. Goldberg E. (2003) Upravliaiushchii mozg: lobnyie doli, liderstvo i civilizatsiia [The Governing Brain: Frontal Lobes, Leadership and Civilization] / E. Goldberg. - M. : Smysl. - 335 p. [in Russian]

6. Goldberg E. (2007) Paradoks mudrosti [The Paradox of Wisdom] / E. Goldberg. - M. : Pokolenie. - 384 p. [in Russian]

7. Hoift G. (2003) Gerontopsihosomatika i vozrastnaia psihoterapiia [Gerontopsysomatics and Age-Related Psychotherapy] / G. Hojft, A. Kruze, G. Radebold. - M. : ACADEMIA (Izdatelskij Centr «Akademiia»). - 370 p. [in Russian]

8. Horn J.L. (1989) The Theory of Fluid and Crystailized Intelligence in Relations to Concepts of Cognitive Psychology and Aging in Adulthood / J.L. Horn // Aging and cognitive processes / Ed. by F.I.M. Craik, S. Trehuh. - New York : Plenu. - P. 76-112. [in English]

9. Huppert F.A. (1994) Memory Function in Dementia and Normal Aging - dimension or dichotomy? / F.A.Huppert // Dementia and Normal Aging / Ed. by F.A. Huppert, C. Brayne, D.W. O'Conner. - Cambridge : Cambridge University Press. - P. 291-330. [in English]

10. Huppert F.A. (1994) What Is the Relationship between Dementia and Normal Aging? / F.A. Huppert, C. Brayne // Dementia and normal ageing / Ed. by F.A. Huppert, C. Brayne, D.W. O’Conner. - Cambridge : Cambridge University Press. - P. 3-11. [in English]

11. Kempler D. (1994) Language in Dementia and Normal Ageing/ D. Kempler, E.M. Zelinski // Dementia and normal ageing / Ed. by F.A. Huppert, C. Brayne, D.W. O'Conner. - Cambridge : Cambridge University Press. - P. 331-365. [in English]

12. Kholodnaia M.A. (2012) Psiholohiia poniatiinogo myshleniia: Ot kontseptualnyh struktur k poniatiinym sposobnostiam [The Psychology of Conceptual Thinking: From Conceptual Structures to Conceptual Abilities] / M.A. Kholodnaia - M.: Izd-vo «Institut psihologii RAN». - 288 p. [in Russian]

13. Korsakova N. K. (1996) Neiropsihologiia pozdnego vozrasta: obosnovaniie kontseptsii i prikladnyie aspekty [Late Age Neuropsychology: Concept and Applied Aspects Ground] // Vestn. Mosk. un-ta. - Ser. 14. Psihologiia. - № 2. - pp. 32-37. [in Russian]

14. Korsakova N.K. (1997) Neirogerontopsihologiia: razvitie idei shkoly A.R. Luriia // I Mezhdunarodnaia konferenciia pamiati A.R. Lurii 
[Neurogerontopsychology: the Development of A.R. Luriia's School Ideas // I International Conference in Memory of A.R. Luriia]. Tezisy dokladov / pod red. E.D. Homskoi. - M.: MGU; RAN; RAO. - pp. 50-51.[in Russian]

15. Kostiuk H.S. (1969) Princip razvitiia v psihologii [The Principle of Development in Psychology] / H.S. Kostiuk // Metodologicheskiie i teoreticheskiie problemy psihologii [Methodological and Theoretical Problems of Psychology]. - M.: Nauka. - pp. 118-152. [in Russian]

16. Kovalenko-Kobylianska I.H. (2011) Spetsyfika nadannia psyhologichnoii dopomogy $\mathrm{z}$ urahuvanniam osoblyvostei pizniogo herontogenezu [The Specificity of Providing Psychological Assistance, Taking into Account the Features of Late Gerontogenesis] [Elektronnyi resurs] / I.G. Kovalenko-Kobylianska // Tehnologii rozvytku intelektu [Intelligence Development Technologies]. T. 1, № 2 Retrieved from www.psytir.org.ua/index.php./technology_intellect_develop/article/view/43. [in Ukrainian]

17. Maksymenko S.D. (2006) Geneza zdiisnennia osobystosti [Genesis of Special Features] / S. D. Maksymenko. - K. : Vydavnytstvo TOV «KMM». -240 p. [in Ukrainian]

18. Psihiatriia pozdnego vozrasta [Psychiatry of Late Age] (2003) / Pod red. Robina Dzhekobi, Katrin Oppengaimer. - K. : Sfera. - T.2. - 507 p. [in Russian]

19. Roshchina I.F. (2015) Issledovanie normalnogo i patologicheskogo stareniia (neiropsihologicheskii podhod) // Medicinskaia psihologiia v Rossii [The Study of Normal and Pathological Aging (Neuropsychological Approach) // Medical Psychology in Russia]: elektron. nauch. zhurn. N 2(31) [Elektronnyj resurs]. - Retrieved from: http://mprj.ru [in Russian]

20. Rozuminnia ta interpretatsiia zhittievogo dosvidu yak chynnyk rozvytku osobystosti : monografiia [Understanding and Interpretation of Life Experience as a Factor of Personal Development : a Monograph] (2013) / za red. N.V.Chepelievoii. - Kirovograd : Imeks-LTD. - 276 p. [in Ukrainian]

21. Siemkova M.P. (2008) Neprozhitaia starost [Unwell old age] [Elektronnij resurs] / M.P.Siemkova // Retrieved from www.samlib/ru/s/ semkowa_m_p /neprozhitayastarostx. Shtml [in Russian]

22. Smolkin A.A. (2004) Sotsiokulturnaia dinamika otnosheniia k starosti [Sociocultural Dynamics of Attitude Towards Old Age]: dissertatsiia na soiskaniie uchenoi stepeni kandidata sociologicheskih nauk po specialnosti 22.00 .04 : Sotsialnaia struktura, socialnyie instituty i processy [Social Structure, Social Institutions and Processes]/ A.A. Smolkin. - Saratov. 144 p. [in Russian]

23. Smulson M.L. (19-20 kvitnia 2010 roku) Kontseptsiia samorozvytku osobystosti H.S. Kostiuka i nagalni vyklyky siogodennia [The Concept of H.S. Kostiuk's Personality Self-Development and Today's Urgent Challenges] / M.L. Smulson // Materialy II Vseukraiinskoho psihologichnoho konhresu, prisviachenogo 110 richnytsi vid dnia 
narodzhennia H.S. Kostiuka. Tom II. - K. : DP «Informatsiino-analitychne ahenstvo». [in Ukrainian]

24. Smulson M.L. (2003) Psyholohiia rozvytku intelektu [Psychology of Intellectual Development] /M.L.Smulson - K.: Nora-druk. - 298 p. [in Ukrainian]

25. Smulson M.L. (2006) Smysl zhizni v mentalnoj modeli mira [Sense of Life in the Mental Model of the World] / M.L. Smulson // Psihologicheskiie problemy smysla zhizni i akme [Psychological Problems of Life Meaning and Acme]: materialy $X$ simpoziuma / Pod red. G.A. Vaizer, E.E. Vahromova. - M. - pp. 28-29. [in Russian]

26. Smulson M.L. (2009) Intelekt i mentalni modeli svitu [Intelligence and Mental Models of the World] / M.L.Smulson // Naukovi zapysky. Seriia «Psihologiia i pedagogika». Tematichnyi vypusk «Suchasni doslidzhennia kognityvnoii psihologii» [Contemporary Studies in Cognitive Psychology] Ostrog: Vid-vo Natsionalnogo universytetu «Ostrog». - Vip.12. pp. 38 - 49. [in Ukrainian]

27. Tsvetkova L.S. (2008) Mozg i intellekt: narusheniie i vosstanovleniie intellektualnoi deyiatelnosti [Brain and Intelligence: Disruption and Restoration of Intellectual Activity] / L.S. Tsvetkova. - M. : Izdatelstvo Moskovskogo psihologo-sotsialnogo instituta. - 424 p. [in Russian]

28. Yeliutina M.E. (1999) Gerontologicheskoie napravleniie v strukture chelovecheskogo bytiia [Gerontological Direction in the Structure of Human Being] / M.E. Yeliutina. - Saratov : Izd. Sarat. gos. un-ta. - 139 p. [in Russian]

29. Yermolaieva M.V. (2008) K voprosu o potentsialah razvitiia lichnosti v starosti [On the Issue of Personality Development Potentials in Old Age] / M.V. Yermolaieva, S.B. Priahina // Mir psihologii [World of psychology]. № 2. - pp. 244-255. [in Russian]

30.Zaporozhets A.V. (1986) Izbrannyie psihologicheskiie trudy [Selected Psychological Works] / A.V. Zaporozhets - V dvuh tomah. - T.1. Psihicheskoie razvitiie rebenka [Child's Mental Development]. - M.: Pedagogika. - 320 p. [in Russian]

\section{Information about the author: Smulson Maryna,}

Real member of the National Academy of Pedagogical Sciences of Ukraine, Professor, Doctor of Psychological Science, Head of Department of Modern Information Technologies of Education, G.S. Kostiuk Institute of Psychology of the National Academy of

Pedagogical Sciences of Ukraine, 2 Pankivska str., Kyiv, Ukraine, 01033 ORCID ID: orcid.org/ /0000-0002-9563-3390 smulson@ukr.net 


\section{LEADER'S ABILITY TO ENSURE THE ESSENTIAL MILITARY STUDY GROUP COHESION LEVEL}

\section{Olena Volobuieva}

Leaders are people who do the right thing. Managers are people who do things right.... A profound difference. Jeorge Washington (Hugh Rawson and Margaret Miner, 2006) ${ }^{1}$

\section{INTRODUCTION}

The professionalization process of the future officer as the future military specialist begins since the very first day of entering the higher military educational establishment when the professional competence formation of every individual in the particular study group is started and the group as human system develops under the tough control of the group leader and the number of well-educated lectures, teachers and trainers. In this particular well-organized system the professional individual development of group members and the very group as an organized system take place step by step and the role of group cohesion as one of the principle factors which determines the professional growing of the future specialists is of vital importance.

The current personality development paradigm of the professional training of the personnel of all the categories of the State Border Guard Service of Ukraine requires from every unit leader to create the necessary didactic-psycho-pedagogical conditions for the effective communication while carrying out moral-psychological providing of the border guards professional activity.

The investigation topicality of this problem is stipulated by the necessity of rise in effectiveness and quality of the borderguard officers professional training, search of the successful vectors of optimization of the moralpsychological providing system, on the one hand, and on the other hand, by the not enough development level of the cadets - the future borderguard officers organizational abilities. In this context it is essential to emphasize the importance of taking into the unit leader's account the socio-

\footnotetext{
${ }^{1}$ Jeorge Washington, copybook, Rules of Civility @ Decent Behavior In Company and Conversation, The Oxford Dictionary of American Quotations / selected and annotating by Hugh Rawson and Margaret Miner, Copyright, 2006, Published by Oxford University Press, Inc. 198 Madison Avenue, New York, New York, p. 403.
} 
psychological determinants of group influence upon the cadets. The proper knowledge of these determinants gives the opportunity to create the motive influences while carrying out the moral-psychological providing with the purpose of actualization of the real possibilities of every group member within the objective measures of individual's potential.

In our investigation we have used the Gordon L. Lippitt's conceptual approach to the individual development of the future officer as the particular ways by which the certain cadet - the future border guard officer learns, matures, and grows as a consequence of the analyzed life experiences on the grounds of 1) positive interaction with the internal and external environments; 2) the participation of the planned education, training and development activities of either a formal and informal nature ${ }^{2}$ (Lippitt, 1982a).

\section{Study group leader's role in professional development of the future borderguard officers}

The scientific sources analysis results testify about the fact that a great number of works have dedicated to the aspects of the leaders role in the professional development process of the future specialists.

Marcus Buckingham and Curt Coffman in their book attract our attention to the fact that manager's role is the catalyst role. They found the manager's function to be the speeder of the reaction between two substances, particularly between individuals' talents and the company's goals ${ }^{3}$ (Buckingham \& Coffman, 2005).

While investigating the peculiarities of professional development of the specialist in the defence environment, Alex Alexandrou and Roger Darby (2006) emphasize that: 1) success in managing people in the defence environment often rests on a manager's interpersonal skills and 2) the manager's ability to create an effective working environment ${ }^{4}$ (Alexandrou $\&$ Darby (2006).

What is important for us is on the basis of revealing the cohesion nature to investigate the survey results (we have conducted in the military

${ }^{2}$ Lippitt, Gordon L. (1982). Organization renewal. A Holistic Approach to Organization Development, Second Edition. Printice - Hall, Inc., Englewood Cliffs, New Jersey, the USA, 418 p., p. XIV.

${ }^{3}$ Buckingham Marcus and Coffman (2005). First, Break the Rules. What the World's Greatest Managers Do Differently. Pocket Books. London-Sydney-New-York-Toronto, Great Britain, Simon @ Schuster UK Ltd. A CBS Company, 303 p., p. 54).

${ }^{4}$ Alexandrou Alex and Darby Roger, 2006, Human resource management in the defense environment. Managing Defense in a Democracy. Edited by Laura R. Cleary and Teri McConville, Routledge: Taylor @ Francis Group, London and New York, pp. 157-178. 
environment in order to 1) determine the study group leader's understanding of their role in the process of forming the group team and 2) to be professionally competent as for sticking military study group together and rise in effectiveness group members' professional activity. That is why the aim of the article is to reveal the investigation results we have achieved within the framework of conducting the special worked out survey on the cohesion level of the study groups in the military environment. After having analyzed the survey results the further directions of the organizational abilities of the military study groups' leaders' development will be defined.

Before carrying out the study for us it was absolutely important to understand the very nature of the group cohesion as the "truly multidisciplinary and interdisciplinary phenomenon ${ }^{5}$ (Lippitt, 1982b). For instance, Henry Kellerman investigates group cohesion from the psychological and psychoanalytical points of view; Jürk W. Tuber considers group cohesion on the grounds of the microbiological theory; Karsten J. Struhl in his group cohesion study reveals the small group processes peculiarities from the philosophical view; Leo Silber dedicates his group cohesion investigation to the aspects of the larger social context; David R. Roth analyses the aspects of social cohesion; John H. Crook studies ethological features of social processes in individual; Robert A. Ravich researches the nature of cohesion in intimate relationships and family structures $^{6}$ (Kellerman et. al.,1981a).

According to the New Oxford Advanced Learner's (2005a) 1) the term "cohesion" means: (n) the action or fact of forming a united whole; 2) the term "cohesive" (adj). characterized by or causing cohesion. ${ }^{7}$

As we consider the cohesion as a phenomenon within the context of group dynamics, first of all, it is important to understand the very group nature and its life functioning on the grounds of the wide variety of the theoretical approaches or orientations to group dynamics. They are the following: 1) Lewin's field theory; 2) interaction theory (according to this theory group is considered to be a system of interacting individuals); 3) the systemic approach (i.e. the group as a miniature social system); 4) sociometry (interpersonal choices viewed as binding groups of people together); 5) psychoanalytic conceptions (motivational and defensive

${ }^{5}$ Lippitt, Gordon L. (1982). Organization renewal. A Holistic Approach to Organization Development, Second Edition. Printice - Hall, Inc., Englewood Cliffs, New Jersey, the USA, 418 p., p. XXVI.

6 Group Cohesion, 1981, Theoretical and Clinical Perspectives. Edited by Henry Kellerman, Grune\& Stratton, Inc. New York.

7 The New Oxford Advanced Learner's Dictionary, Second Edition, Published by Oxford University Press, 2005, Inc. 198 Madison Avenue, New York, New York,. 2051 p., p. 330 
processes within the individual); 6) cognitive theory (Gestalt emphasis on individual perceptual organization of one's environment ${ }^{8}$ (Weston, 1998a).

\section{Leaders's consciosness as the sense of "we-ness"}

In our investigation we have taken into our consideration the fact that consciousness according to Robert S. Feldman is the awareness of the sensation, thoughts and feelings being experienced at a given moment The scientist finds consciousness to be one's subjective understanding of both the environment around us and our private internal world ${ }^{9}$ (Feldman, 1999a).

For leader it is essential to remember that cohesiveness according to Robert Kreitner and Angelo Kinicki is a sense of "we-ness" which helps to stick group members together They have defined two types of cohesiveness, particularly: 1) socio-emotional cohesiveness (is the sense of togetherness that develops when individuals derive emotional satisfaction from group participation); 2) instrumental cohesiveness (the sense of togetherness that develops when group members are mutually dependent on one another because they believe they could not achieve the group's goal by acting separately ${ }^{10}$ (Kreitner \& Kinicki, 1998).

In the study of groups, the two key variables are the following: 1) cohesiveness (i.e. the sum of the forces that bind an individual to the group, it is vital in determining the group's influence over its members. Research has shown its close interrelationship with other variables, such as communication and conformity; 2) locomotion (it signifies the group movement towards a desired goal) ${ }^{11}$ (Weston, 1998b).

\section{Military study group cohesion and its influence upon the organization of communication in the system «leader - group members»}

It goes without saying that while carrying out the psychological influence upon the personnel professional activity every leader has to take into her/his consideration the fact that the important index (indicator) of the interpersonal relationships between the personnel (group members) is the very cohesion level.

\footnotetext{
${ }^{8}$ Weston Louise C. (1998). Group Dynamics. The Encyclopedia Americana - International Edition, Grolier Incorporated, Volume 13, 922 p., p. 517.

${ }^{9}$ Feldman Robert S. (1999). Understanding Psychology. Fifth Edition McGrow-Hill, the USA, 774 p., p., 146).

${ }^{10}$ Kreitner Robert and Kinicki Angelo (1998) Organizational Behavior. Fourth Edition, Irwin/McGrow-Hill, Copyright, 670 p., p.402.

11 Weston Louise C. Group Dynamics. The Encyclopedia Americana - International Edition, Grolier Incorporated, Volume 13, 1998, 922 p., p. 517).
} 
S. A. Bagretsov, V. M. L'vov, V. V. Naumov, K. M. Oganyan in their research proved that cohesion is one of the main group indicators. It characterizes the degree of predominance of affections over dislikes of every group member towards the rest of the group members ${ }^{12}$ (Bagrecov S. A. et. al., 1999a).

The certain study author's experience, some observations results (we use the naturalistic observation study ${ }^{13}$ (Goodwin, 2005a) in order to study the behaviors of the study group members as they act in their 24 hours environment: in the barracks, at the lessons and trainings and at night time during the shifts when the cadets carry out their various guard duties; the analysis results of the moral up-bringing influence, training results, questionnaire of the unit leaders, teachers, officers and the cadets, testify about the fact that nowadays the moral-psychological providing of the border guard professional activity not always reaches the final objective. That is why the aims of our study: are the following 1) to investigate the psychological determinants of cohesion of border guard cadets study group as the small group with the external status (that influence upon the organization of the professional activity of the personnel of the State Border Guard Service of Ukraine); and 2) on the basis of the investigation results to determine the ways of leaders' organizational abilities development which, in its turn, will rise in cohesion level in the study groups in the conditions of the higher military educational establishments; 3 ) to work out the practical recommendations on the increasing the group cohesion level for the study group leaders.

It is absolutely essential for study group leaders to have some knowledge of the cohesion expressiveness level in the particular study group of this psychological phenomena because the effectiveness of the various joint activity forms of group members and development of the necessary professional skills and habits depend greatly on it.

Moreover, for successful study group management it is of vital importance to devote some time and attention to acquiring some knowledge on group socio-psychological processes that form group cohesivenessans also revealing these phenomena in the group formation dynamics in the context of professional training of the future border guard officers. In its turn it gives a leader the opportunity: 1) to provide cohesive cooperation and

${ }^{12}$ Bagrecov S. A. (1999). Diagnostika socialno-psihologicheskih harakteristik malyh grupp $s$ vneshnim statusom [Diagnostics of social-psychological characteristics of small groups with the external status] / S. A. Bagrecov, V. M. Lvov, V. V. Naumov, K. M. Oganyan. - SPb. :Lan, izdatelstvo Sankt-Peterburgskogo universiteta MVD Rossii, 1999. - 640 s. [in Russian], p. 126.

${ }^{13}$ Goodwin C. James Research in Psychology. Methods and Design. Fourth Edition, Wiley. John Wiley@ Sons, Inc., the USA, 556 p., 2005. p. 393). 
effective mutual activity of group members in order to form the essential level of professional competence, i.e. the abilities to carry out the professional duties up to the level.

In the context of our research it is important for us to use Henry Kellerman (1981) conceptual view as for the term group cohesion, particularly the scientist finds this phenomenon to be related to 1) the affiliation needs of individuals; 2) the particular punitive structure of groups - that is, deep group cultural structures; 3) the nature of the leadership; 4) group process $)^{14}$ (Kellerman \& et. al., 1981b).

\section{Survey research sociometrical evaluation of study group cohesion level in the conditions of the higher military educational establishment}

In order to evaluate the moral-psychological climate and group processes in the study group in the conditions of the higher military educational establishment the sociometrical study has been conducted. Sociometry is the quantitative study and measurement relationships within a group of people ${ }^{15}$ (The New Oxford Advanced Learner's Dictionary, 2005b) and in the research we used Jacob L. Moreno's Quantitative Method for measuring social relationships. (In our study we have used the sociometry (a set of methods created by J. L. Moreno to study the interpersonal relationships ${ }^{16}$ (Hale, 2009) for measuring the cohesion level_the study groups. Sociometry has given us the opportunity to evaluate the study group cohesion degree, to determine the group members social status and also to reveal the micro groups) ${ }^{17}$.

We also have taken into our consideration that groups are human system in which the members are interdependent and share an identity. All groups have a structure and boundaries that both separate and join them in their environment ${ }^{18}$ (Longres, 1995a) social control mechanisms, and socially

\footnotetext{
14 Group Cohesion, 1981, Theoretical and Clinical Perspectives. Edited by Henry Kellerman, Grune\& Stratton, Inc. New York, 465 p. , p. 4.

${ }^{15}$ The New Oxford Advanced Learner's Dictionary (2005), Second Edition, Published by Oxford University Press, Inc. 198 Madison Avenue, New York, 2051 p., p.1610.

${ }^{16}$ Hale Ann E. Moreno's Sociometry: Exploring Interpersonal Connection. Group. Vol. 33, No. 4, Psychodrama (December 2009 pp.347-358), Published by Eastern Group Psychotherapy Society, (p. 347) (www.jstor.org/stable/41719254?seq=1).(accessed 10.12.2019).

${ }^{17}$ Rayigorodskyi S. V. (2006). Mnogourovnevyj lichnostnyj oprosnik «Adaptivnost» (MLOAM) A.G. Maklakova i S.V. Chermyanina / Prakticheskaya psihodiagnostika. Metodiki i testy [Multilevel personal questionnaire "Adaptation" (MLO-AM. Practical psychodiagnostics. Methods and tests]. Uchebnoe posobie. Red. i sost. Rajgorodskij D.Ya. - Samara. [in Russian] $672 \mathrm{p}$.

${ }_{18}$ Longres John F. Human Behavior in the Social Environment. Second Edition. F. E. Peacock Publishers, Inc. Itasca, Illinois. Copyright, 1995, 568 p.,p.318.
} 
organized interaction patterns ${ }^{19}$ (Huge, William, Helmreich, McCord, 1992). That is why in our investigation we follow the idea of C. James Goodwin about the fact that the very survey research is based on the simple idea that if you want to find out what people think about some topic, just ask them. According to C. James Goodwin's definition a survey is a structured set of questions or statements given to a group of people to measure their attitudes, beliefs, values, or tendencies to act ${ }^{20}$ (Goodwin, 2005b).

And for our study was absolutely important to take into our consideration the fact that as systems, the groups have the typical attributes. Let us consider them in more details. The investigation results of John F. Longres indicate that groups have seven attributes ${ }^{21}$ (Longres, 1995b), particularly:

1) independence, i. e. each group has the particular collection of individuals and each its member is unique, but at the same time, all group members are interdependent;

2) structure, i.e. a group has the specific internal organization consisting the particular working/service agreements or norms and a division of labor marked by roles and statutes;

3) identity, i.e. (every group is self-conscious entity and emphasizes that group members see themselves as "us";

4) boundaries, i.e. within a group the boundaries are marked physically by the space it occupies; from the psychological point of view the group boundaries are marked by the personalities of the group members; and socially the boundaries are characterized as having its sense of self and its special norms and traditions ${ }^{22}$ (Longres,. 1995c);

5) organization as a holon (according to the conceptualization of the holon it means the idea that every social system is simultaneously a whole and a part of a whole ${ }^{23}$ (Longres, 1995d) i.e. a group is at the same time a whole_in itself and part of another whole; it exists within a social environment;

6) openness, i.e. a group, like individual, is an open system that cannot exists independently of her or his social environment and must interact with it;

\footnotetext{
${ }^{19}$ Hugh Lena F., Helmreich William B., McCord William (1992). Contemporary Issues in Society, McGrow-Hill,, 556 p., p. 31.

${ }^{20}$ Goodwin C. James Research in Psychology. Methods and Design. Fourth Edition, Wiley. John Wiley@ Sons, Inc., the USA, 556 p., (2005), p. 402).

${ }^{21}$ Longres John F. Human Behavior in the Social Environment. Second Edition. F. E. Peacock Publishers, Inc. Itasca, Illinois. Copyright, 1995, 568 p., p. 318.

${ }^{22}$ Longres John F. (1995). Human Behavior in the Social Environment. Second Edition.

F. E. Peacock Publishers, Inc. Itasca, Illinois. Copyright, 568 p, pp. 319-20.

${ }^{23}$ Longres John F. (1995). Human Behavior in the Social Environment. Second Edition. F. E. Peacock Publishers, Inc. Itasca, Illinois. Copyright, 568 p. , p. 46.
} 
7) dynamism, i.e. it is typical of a group that: 1) there is the independence among the group members and 2) there is openness with the environment (that is why a group is dynamic ${ }^{24}$ (Longres, 1995e) and in this context we have to stress and it is important for our study that the term "group dynamics" means the processes involved when people in a group interact with each other ${ }^{25}$ (The New Oxford Advanced Learner's Dictionary, 2005c),

In his research Rafael Steinberg (1975) mentioned that depending on the nature of the organization, the very exacting performance in the particular organization the organization must have clear communication channels through which its goals and commands can be transmitted ad acknowledged... and it must keep a sharp eye on its own decision-making process. Rafael Steinberg points out that the organization's decisions determine its future ${ }^{26}$ (Steinberg, 1975).

In the system of the professional training it is of vital importance to remember about the group support within the framework of the study group development in general and individual development in particular. The very group experience provides numerous healing factors that are intrinsic to the group process (such as the thoughts validation, emotions, and stress reactions ${ }^{27}$ (Willis Dan, 2014).

Moreover, as we conducted the cohesion study in the military environment, while carrying out the research we took into our consideration the fact that it is typical of groups in the military environment to have the "nature of compliance" This term was suggested by Amatai Etzioni. According to the "nature of compliance" the scientist gives three categories of organizations, namely: 1) coercive, normative utilitarian ${ }^{28}$ (Etzioni, 1971).

Rafael Steinberg (1975a) stresses that in the military organizations everyone knows her/his place the individual knows who reports to him, and to whom these individual reports in turn. Commissioned officers receive their appointments from a higher authority. In his research the scientist attracts our attention to the fact that in peacetime a volunteer army is primary utilitarian. Some soldiers may enlist for patriotic reasons but one of them probably sign up for the pay, to see the world or to get an education. And he

\footnotetext{
${ }^{24}$ Longres John F. (1995). Human Behavior in the Social Environment. Second Edition. F. E. Peacock Publishers, Inc. Itasca, Illinois. Copyright, 568 p., p. 320.

${ }^{25}$ The New Oxford Advanced Learner's Dictionary (2005), Second Edition, Published by Oxford University Press, , Inc. 198 Madison Avenue, New York, 10016, 2051 p.

${ }^{26}$ Steinberg Rafael (1975). Man and the Organization. Human Behavior, Time-Life Books, New York, 176 p., p.66.

27 Willis Dan (2014). Bulletproof Spirit. The First Responder's Essential Resource for Protecting and Healing Mind and Heart. New World Library, the USA. 14 Pamaron Way, Novato, California, Copyright, 2014, - 230 p., p. 90.

${ }^{28}$ Amatai Etzioni (1971) A Comparative Analysis of Complex Organizations, 366 p.
} 
makes the conclusion that: 1) in the military organization the compliance system shifts drastically when the guns start firing; 2) no army could pay its soldiers enough to compensate for the risks and hardships of war; troops must be motivated by other methods in order to appeal to patriotism ${ }^{29}$ (Rafael Steinberg, 1975b).

The set of sociometrical methods were used at the end of the special period of the cadets - the future officers when they studied together for the definite period of time - with the purpose of group dynamics evaluating in general and the military unit cohesion level in particular. We have conducted our study in the period when the cadets had known each other in a proper well for the particular period of time while studying and also carrying out the professional duties after classes.

In our research we have taken into our consideration the results of the processes involved when the cadets in a group interact with each other, that is we have studied group dynamics.

The social and interpersonal relations are connected greatly that is why the study groups of their nature are considered to be the combination of relationships within a group of cadets (collaboration, competition, cohesion, compatibility, agreement and harmony, friendship, dislike, hostility etc.) and personal character traits and qualities which influence the psychological peculiarities of communication process within the particular study group (openness, politeness, respect, unsociability, independence, sensitiveness, adherence to principle, honesty, responsibility etc.).

The dominant relationships in the group determine its structure and sociometry - is the most effective method of studying the structure of nonformal interpersonal relationships which are typical of the study group, evaluating of popularity (non-popularity) of all the group members, revealing of non-formal group leader, micro-groups, determining the sociopsychological compatibility (non-compatibility) of group members in the conditions of the team work/activity.

1. The sociometry method is rather informative and on the other hand it is not complicated. Such method gives us the opportunity to reveal the individual's desire (or unwillingness) for interaction with other people in the concrete conditions, to reveal the leader (leaders) and also to determine the group organization level ${ }^{30}$ (Bagrecov et. al. ,1999b). Our survey research

${ }^{29}$ Steinberg Rafael (1975) Man and the Organization. Human Behavior, Time-Life Books, New York, 176 p. p.67-69).

${ }^{30}$ Bagrecov S. A. (1999). Diagnostika socialno-psihologicheskih harakteristik malyh grupp $s$ vneshnim statusom [Diagnostics of social-psychological characteristics of small groups with the external status] / S. A. Bagrecov, V. M. Lvov, V. V. Naumov, K. M. Oganyan. - SPb. :Lan, izdatelstvo Sankt-Peterburgskogo universiteta MVD Rossii, 1999. - 640 s. [in Russian]. 
was based on the simple idea that if you want to find out what people think about the certain topic in our case - the level of interpersonal relations, just ask them ${ }^{31}$ (Goodwin, 2005c). We conducted our research in the form of questionnaire of all the group members with the purpose of study the individual opinions the all group members as for the aspects we are interested in, particularly each individual was asked the certain question on the her/his personal attitude towards the other group members.

Before writing the survey, the instructor explains the group members (the respondents) the purpose of the survey and the ways of doing it and only after that they filled it in written form.

While carrying out the sociometric investigation it is essential to take into one's account the following conditions (aspects):

the survey study must be conducted by the instructor - a person who is unknown to group members and who asks the group to perform a particular task;

a group has to consist of the cadets who have been known each other due to reconcile activity (of the period no less than 2-3 months);

the number of group members of each study group have to be limited strictly (in our study: it is the structural unit);

the condition, which suggested for consideration, is to be formulated in such a way, that it is clear for everyone and gives the opportunity interpersonal relationships at the individual level.

In our research we used the sociomatrix in the form of the statistical table, where the positive and negative choices are located (we used the same number of the tables as the number of the study group members).

The sociomatrix analysis gave us the opportunity to evaluate the member groups' answers according to the number of positive and negative choices we had achieved; to reveal micro groups of persons with mutual positive choices, conflict pairs and persons with no authority in the groups.

While evaluating the sociometrical results we calculated the sociometrical personal and group indexes that characterize the relationships in the particular study group quantitatively. The personal indexes permitted us to reveal the certain individual' characteristics and qualities in the group quantitatively. We described the group characteristics with the help of the group indexes in general.

It is essential to point out that the personal sociometrical indexes and the indexes of group members' emotional expansivity belong to the sociometrical status indexes. The sociometrical status index 1) reflects the

31 Goodwin C. James (2005). Research in Psychology. Methods and Design. Fourth Edition, Wiley. John Wiley @ Sons, Inc., the USA, 556 p., p. 402. 
general (favorable or not favorable one) position of the particular cadet - the future border guard officer in the group; the group attitude towards the certain cadet; 2) characterizes the level of the cadet's potential leadership.

The index of the emotional expansivity characterizes the individual's attitude towards the group and needs for communication and collaboration activity.

The sociometrical status index of the certain individual in the group is calculated by the formula

$$
C=\frac{(B+)+(B-)}{n-1},
$$

Where $C$ - the sociometrical status of the certain group member; $(B+)-$ the sum of positive choices, which had been got by the certain group member (the index is calculated in the vertical sociomatrix column); $(B-)-$ the sum of the negative choices, received by the certain group member; $n-$ the number of the group members, who participated in the investigation.

On the basis of these results we can compare the group members according to their authority and influence upon the group behavior.

The individual emotional expansivity index is calculated by the formula

$$
E=\frac{(A+)+(A-)}{n-1},
$$

where $E$ - the emotional expansivity of the certain group member; $(A+)$ - the positive choices made by the certain group member as for the group members; $(A-)$ - the negative choices made by the certain group member as for the group members; $n$ - the number of the group members.

The group members sociometrical status and emotional expansivity indexes (i.e. the individual indexes), can be served as the basis for the comparison with the other group members.

The cohesion index and conflict index belong to the group indexes.

The group cohesion index is measured by the ratio of the number of made mutual choices towards the number of the theoretically possible mutual positive relationships:

$$
G=\frac{D+}{n \cdot(n-1)},
$$

where $G$ - the group cohesion index; $(D+)$ - the total number of the mutual positive choices; $n-$ the number of the group members. 
The index permits to compare the different groups according to the cohesion degree. The conflict index is determined in the same way but only according to the results of the negative choices.

$$
K=\frac{S-}{n \cdot(n-1)},
$$

where $K-$ the group conflict index; $S--$ the total number of mutual negative choices; $n$ - the number of the group members.

In our research we have used the $100 \%$ scale of the evaluation of the group cohesion index for the general analysis of the study groups development level, particularly:

up to $25 \%$ - the lowest level of the study group development (this level is characterized by the first cohesion signs);

25-50\% - the law study group development level;

51-75\% - the middle study group development level;

$76-100 \%$ - the high study group development level.

Thus, the main purpose of the sociometrical method usage was to evaluate the cohesion level in the unit group and on the basis of the study results to create the special program aimed at the increasing level of the cohesion level of the military units with the positive moral-psychological atmosphere, which is of vital importance for the effective carrying out leader's professional tasks within the framework of upbringing and training the cadets - the future border guard officers according to the up-to-date requirements of the higher military education.

Taking into our consideration all the above-mentioned peculiarities and principles we conducted the detailed investigation and analysis of the cohesion index in the study groups of the National Academy of the State Border Guard Service of Ukraine named after Bohdan Khmelnitsky (NASBGSU) where the professional training of the future border guard officers is conducted. The research was held in the period of 2018 and 2019 years.

As the sociometric investigation is to be conducted only after the sixmonth period of the study group formation, and taking into our account the fact that in the second year of cadets' studying the specialization redistribution takes place, the third-year cadets were chosen for the investigation (2018 year). After that in a year we conducted the analogical investigation and analysis in the same study groups (2019 year).The statistical testing results are given in Table 1. (The cohesion index has been converted into the $100 \%$ scale for the calculations convenience). 
With the help of T- Wilcoxon criterion, we examined whether the cohesion level displacement occurred or not ${ }^{32}$ (Sydorenko, 2000).

Table 1

Statistical investigation of cohesion level changes in the cadets' study groups (the third and fourth years of studying at NASBGSU)

\begin{tabular}{|c|c|c|c|c|c|c|c|}
\hline \multirow[b]{2}{*}{ № } & \multirow[b]{2}{*}{$\begin{array}{c}\text { Study } \\
\text { group } \\
\text { number }\end{array}$} & \multirow[b]{2}{*}{$\begin{array}{l}\text { Number } \\
\text { of cadets }\end{array}$} & \multicolumn{2}{|c|}{ Cohesion level } & \multirow[b]{2}{*}{$t_{4} t_{3}$} & \multirow[b]{2}{*}{$\left|t_{4} t_{3}\right|$} & \multirow[b]{2}{*}{$\begin{array}{c}\text { Chang } \\
\text { e rank } \\
\text { numbe } \\
\mathbf{r}\end{array}$} \\
\hline & & & $\begin{array}{c}t_{3}(\text { the } \\
\text { 3-d } \\
\text { studyin } \\
\text { g year) } \\
2017\end{array}$ & $\begin{array}{c}t_{4} \\
\text { (the 4-th } \\
\text { studying } \\
\text { year) } \\
2018\end{array}$ & & & \\
\hline 1 & 241 & 19 & 75 & 80 & 5 & 5 & 6,5 \\
\hline 2 & $242 / 1$ & 19 & 80 & 79 & -1 & 1 & 1 \\
\hline 3 & $242 / 2$ & 10 & 82 & 97 & 5 & 5 & 6,5 \\
\hline 4 & $243 \mathrm{k}$ & 10 & 93 & 98 & 5 & 5 & 6,5 \\
\hline 5 & $243 t$ & 15 & 95 & 97 & 2 & 2 & 2,5 \\
\hline 6 & 244 & 25 & 74 & 81 & 7 & 7 & 11 \\
\hline 7 & $341 / 1$ & 10 & 81 & 79 & -2 & 2 & 2,5 \\
\hline 8 & $341 / 2$ & 13 & 84 & 81 & -3 & 3 & 4 \\
\hline 9 & 342 & 33 & 88 & 94 & 6 & 6 & 9,5 \\
\hline 10 & 441 & 19 & 91 & 96 & 5 & 5 & 6,5 \\
\hline 11 & $\begin{array}{l}541 / 1, \\
541 / 2 \\
\end{array}$ & $12+5$ & 84 & 91 & 6 & 6 & 9,5 \\
\hline \multicolumn{2}{|c|}{ Total } & 190 & & & 35 & 66 & 66 \\
\hline
\end{tabular}

Groups 541/1 and 541/2 had been united before the investigation because the cadets from the both groups had spent the considerable part of their time together and moreover the biggest part of the subjects they had studied were learned at the same time.

The results of the investigation testify about the fact that the cohesion level in almost all the study groups (with the exception of three study groups $242 / 1,341 / 1,341 / 2$ ) is high and in general during the year the changes as for increasing groups cohesion level occurred. T-Wilcoxon criterion was chosen for the statistical verification and all the restrictions of which had been observed. The statistical hypotheses have been formulated in the following way:

the main hypothesis: $H_{0}$ - the displacement intensity as for the increasing of the cohesion levels does not exceed the displacement intensity as for reducing;

${ }^{32}$ Sidorenko E. V. (2000). Metodyi matematicheskoy obrabotki v psihologii [Methods of Mathematical Processing in Psychology. S-Pb.: Rech Publ. [in Russian]. 350 p. 
the competitive hypothesis: $H_{1}$-the displacements intensity as for cohesion levels increasing exceeds the displacement intensity as for reducing.

The empirical criterion value has been calculated by the formula:

$$
T_{\text {eMn }}=\sum R_{r}
$$

Where $R_{r}$ - rank valued is placements with the most seldom sign.

In our case it is marked by another color in the table 1 (particularly in the groups 242/1, 341/1, 341/2).

We compared the received empirical value criterion with the critical value of the relative level of the statistical relevance (1.5):

$$
T_{\kappa p}^{*}=\left\{\begin{array}{l}
13(p \leq 0,05) \\
7(p \leq 0,01)
\end{array}\right.
$$

In our case $-* T_{\text {eMn }}=1+2,5+4=7,5$ permits to assert that the displacements intensity as for the increasing of the cohesion level is more than the displacements intensity as for the reducing. In this case the mistake obviousness is not more than $5 \%$.

\section{CONCLUSION}

Having investigated the peculiarities of the individual relationships in the study groups in the conditions of the higher military educational establishment as for the determining the certain cohesion level of the cadets - future border guard officers on the grounds of the survey study we have obtained the results we are interested in, namely:

1) the specific aspects of the study group life as the nature and requirements of leadership, the different roles of the group members, friendship or attraction in the groups, and the process of making decisions in the groups;

2) the research also has provided us with the essential information on the cadets' individual communications and relationships among members in the particular study groups, and the hidden forces that influence the way the groups members do and behave in the group;

3 ) we have got the new ideas about the aspects on the high morale and effective action in groups which are so important for providing the effective professional development of the cadets - the future borderguard officers.

The leader's role in the process of developing the study group members' professional abilities is of vital importance. 
And it is important for the senior officers and the study group leaders together with teachers to organize the training system in such a way that cadets feel some comfort and help them to achieve professional competence by making sure that they have skills necessary to attain the desired goals ${ }^{33}$ (Thomas et. al., 2000). The very environment influences upon the group structure $^{34}$ (Show, p.243). For creating well-organized study environment in groups it is necessary to remember about the fact that the group members must not be psychologically distressed. So it is the fundamental concerns of the positive psychology ${ }^{35}$ Furnham, 2008).

As groups develop and hold the norms, expectations regarding behavior appropriate to the group ${ }^{36}$ (Feldman, 2009b). It is of vital importance to take into study group leader's consideration the very peculiarities of human attitudes, opinions and behaviors of all the study group members in the process of teaching and training activity management ${ }^{37}$ (Mashbyts, 2019) on the grounds of high responsibility for intellectual activity ${ }^{38}$, In this context we have taken into our account the fact that groups are not simply collections of individuals. Groups are systems ${ }^{39}$ (Longres, 1995f) and for a study group leader it is essential to understand that upper and lower limits on practical problem-solving are determined by a set of underlying basic competencies and by the interactions among these competencies the manner in which practical problem-solving develops is restricted by the development of the basis cognitive abilities. The variations within these limits are determined by individual historical factors (e.g. education, job complexity, etc. $^{40}$ (Blanchard-Fields \& Hess, 1996), individual, age and gender peculiarities.

33 Education Psychology (2000). Effective Teaching, Effective Learning. Krtochwill Thomas R., Cook Jan Littlefield, Travers John F. Third Edition. Mc Grow-Hill Higher Education, the USA. - 631 p., p. 366.

${ }^{34}$ Shaw Marvin E. (1976), Group Dynamics. The Psychology of Small Group Behavior, McGraw-Hill Book Company, the USA, 464 p., p. 18.

${ }^{35}$ Furnham Adrian (2008). 50 ideas you really need to know. Psychology, Quercus Edition Ltd, 55 Baker Street, $7^{\text {th }}$ Floor, South Block, London, W1U8EW, Printed and bound in China, 208 p., pp. 52-53.

${ }^{36}$ Feldman (2009). Robert S. Understanding psychology. McGrow-Hill, 2009, 622 p.,p.595.

37 Mashbyts Yu. I. (2019). Psykholohichni mekhanizmy I tekhnolohiia navchannia [Psychological mechanisms and technology of teaching]. K.: Interservis [in Ukrainian], 208 p. p. 133

${ }^{8}$ Smulson M.(2019) The significance of problem-solving in the professional activity. Psychological Basis of Professional Problem Solving : collective monograph / M. Smulson, M. Tomchuk, A. Chornyi, V. Demskyi, A. Makovskyi, Anatolii Yakymchuk, T. Scherbana, O. Volobuieva. - Lviv-Toruń : Liha-Pres, 2019. - 178 p. pp.1-21. (ISBN 978-966-397-152-0).

${ }^{39}$ Longres John F. (1995). Human Behavior in the Social Environment. Second Edition.

F. E. Peacock Publishers, Inc. Itasca, Illinois. Copyright, 568 p., p. 319.

${ }^{40}$ Fredda Blanchard-Fields, Thomas M. Hess. Perspectives on Cognitive Change in Adulthood and Aging, McGrow-Hill, 1996, 537 p., p. 333. 


\section{SUMMARY}

The article deals with the investigation results of the leader's ability to form the essential cohesion level in the study groups of the cadets - future border guard officers. The survey study results testified about the necessity of the further border guard officers' organizational abilities development in the system of the professional training in the conditions of the military educational establishment, the essential level of which is the basis of the proper study group cohesion level. In its turn it ensures the effectiveness of the professional training and as a result, - the necessary level of the future border guard officers professional competence formation.

The results of the study have indicated that not all the study group leaders have the necessary level of the organizational abilities and as the consequences the cohesion level in the three experimental groups were not up-to-the level. That is why it is essential to work out the special program on the purposeful development of the organizational abilities of the border guard officers and the cadets - the future border - guard officers. The welldeveloped organizational abilities and proper knowledge of the individual, age and gender group members peculiarities will make it is possible for the study group leaders to form the essential level of the professional competence of the cadets and as a result they will carry out the professional activity successfully after having graduate.

The size of the article does not permit to reveal all the investigation esults. The further investigation ways of the problem of the leaders' organizational abilities development in the military environment are the following: 1) studying the role of the leader's consciousness in the process of the effective study group management and development; 2) working out the Program on the future borderguard officers' organizational abilities development.

\section{REFERENCES}

1. Alexandrou Alex and Darby Roger (2006). Human resource management in the defense environment. Managing Defense in a Democracy. Edited by Laura R. Cleary and Teri McConville, Routledge: Taylor @ Francis Group, London and New York, pp.157-178.

2. Bagrecov S. A. (1999). Diagnostika socialno-psihologicheskih harakteristik malyh grupp s vneshnim statusom [Diagnostics of socialpsychological characteristics of small groups with the external status] / S. A. Bagrecov, V. M. Lvov, V. V. Naumov, K. M. Oganyan. - SPb. :Lan, izdatelstvo Sankt-Peterburgskogo universiteta MVD Rossii, 1999. - 640 s. [in Russian].

3. Blanchard-Fields Fredda, Hess Thomas M. (1996). Perspectives on Cognitive Change in Adulthood and Aging. McGrow-Hill, 537 p. 
4. Buckingham Marcus and Coffman (2005). First, Break the Rules. What the World's Greatest Managers Do Differently, Pocket Books. London-Sydney-New-York-Toronto, Great Britain, Simon@ Schuster UK Ltd. A CBS Company, 303 p.

5. Education Psychology (2000). Effective Teaching, Effective Learning. Kratochwill Thomas R., Cook Jan Littlefield, Travers John F. Third Edition. Mc Grow-Hill Higher Education, the USA. - 631 p.

6. Etzioni Amatai. (1971). A Comparative Analysis of Complex Organizations.

7. Feldman Robert S. (1999). Understanding Psychology. Fifth Edition. McGrow-Hill, the USA, $774 \mathrm{p}$.

8. Furnham Adrian (2008). 50 ideas you really need to know. Psychology, Quercus Edition Ltd, 55 Baker Street, $7^{\text {th }}$ Floor, South Block, London, W1U8EW, Printed and bound in China, 208 p.

9. Goodwin C. James (2005). Research in Psychology. Methods and Design. Fourth Edition, Wiley. John Wiley @ Sons, Inc., the USA, 556 p.

10. Group Cohesion. Theoretical and Clinical Perspectives. Edited by Henry Kellerman (1981), Grune\& Stratton, Inc. New York, 465 p.

11. Hale Ann E. Moreno's Sociometry: Exploring Interpersonal Connection. Group. Vol. 33, No. 4, Psychodrama (December 2009, pp. 347-358), published by Eastern Group Psychotherapy Society, (p. 347) (www.jstor.org/stable/41719254?seq $=1$ ), accessed on the $10^{\text {th }}$ of December 2019.

12. Hugh Lena F., Helmreich William B., McCord William (1992). Contemporary Issues in Society, McGrow-Hill,, 556 p.

13. Kreitner Robert and Kinicki Angelo (1998). Organizational Behavior. Fourth Edition, Irwin/McGrow-Hill, Copyright, 670 p.

15. Lippitt, Gordon L. (1982). Organization renewal. A Holistic Approach to Organization Development, Second Edition. Printice - Hall, Inc., Englewood Cliffs, New Jersey, the USA, -418 p.

16. Mashbyts Yu. I. (2019). Psykholohichni mekhanizmy I tekhnolohiia navchannia [Psychological mechanisms and technology of teaching]. K.: Interservis [in Ukrainian], 208 p. p. 133.

17. Longres John F. (1995). Human Behavior in the Social Environment. Second Edition. F. E. Peacock Publishers, Inc. Itasca, Illinois. Copyright, $568 \mathrm{p}$.

18. Rayigorodskyi S. V. (2006). Mnogourovnevyj lichnostnyj oprosnik «Adaptivnost» (MLO-AM) A.G. Maklakova i S.V. Chermyanina / Prakticheskaya psihodiagnostika. Metodiki i testy [Multilevel personal questionnaire "Adaptation" (MLO-AM. Practical psychodiagnostics. Methods and tests]. Uchebnoe posobie. Red. i sost. Rajgorodskij D.Ya. Samara. [in Russian] 672 p. 
19. Sidorenko E. V. (2000). Metodyi matematicheskoy obrabotki $v$ psihologii [Methods of Mathematical Processing in Psychology]. SPb.: Rech Publ. [in Russian].

20. Shaw Marvin E. (1976), Group Dynamics. The Psychology of Small Group Behavior, McGraw-Hill Book Company, the USA, 464 p.

21. Smulson M. (2019) The significance of problem-solving in the professional activity. Psychological Basis of Professional Problem Solving : collective monograph / M. Smulson, M. Tomchuk, A. Chornyi, V. Demskyi, A. Makovskyi, Anatolii Yakymchuk, T. Scherbana, O. Volobuieva. - LvivToruń : Liha-Pres, 2019. - 178 p., pp.1-21.

20. Steinberg Rafael (1975) Man and the Organization. Human Behavior, Time-Life Books, New York, 176 p.

21. The New Oxford Advanced Learner's Dictionary (2005), Second Edition, Published by Oxford University Press, , Inc. 198 Madison Avenue, New York, 10016, $2051 \mathrm{p}$.

22. The Oxford Dictionary of American Quotations / selected and annotating by Hugh Rawson and Margaret Miner (2006), Copyright, Published by Oxford University Press, Inc. 198 Madison Avenue, New York, New York, 10016, 898 p.

23. Weston Louise C. (1998). Group Dynamics. The Encyclopedia Americana - International Edition, Grolier Incorporated, Volume 13, 922 p., p. 517.

24. Willis Dan (2014). Bulletproof Spirit. The First Responder's Essential Resource for Protecting and Healing Mind and Heart. New World Library, the USA. 14 Pamaron Way, Novato, California, Copyright, 2014, 230 p.ON

\section{Information about the author: Olena Volobuieva,}

Doctor of Sciences in Psychology, Professor,

Deputy Rector for Research, National Academy of the State Border Guard Service of Ukraine named after Bohdan Khmelnytskyi 46 Shevchenko str., Khmelnytskyi, 29003, Ukraine

ORCID ID: orcid.org/0000-0003-4010-6398 helen_volobueva@ukr.net 


\section{THE TEACHER'S EMOTIONAL COMPETENCE IN SUBJECT- SUBJECT INTERACTION WITH FUTURE OFFICERS-BORDER GUARDS IN FOREIGN LANGUAGE LEARNING ENVIRONMENT}

\section{Valentyna Hrishko-Dunaievska}

\section{INTRODUCTION}

Modern social processes, social and political situation create new threats in the national security system, especially in the field of state border protection. This problem is strongly addressed to the State Border Service of Ukraine (SBGSSU) as new tasks and functional responsibilities of border guards emerge in the context of integrated border management.

In order to create a single area of European higher linguistic education, there was a need to reformat the interaction process between the teacher and future officers, where an adequate level of foreign language skills is one of the main professional competence components. The need for highly qualified specialists is growing especially due to the international cooperation between the border agencies of the world countries, the European Union's attention to the border protection problems, international cooperation of Ukraine with law enforcement and security agencies, intensification of participation of the Ukrainian servicemen in joint operations, trafficking in human beings, drugs and weapons, interaction with international organizations representatives. Taking into account Ukraine's cooperation in the framework of the NATO-Ukraine Professional Development Program on military reforms and within the framework of the STANAG 6001 agreement on defining the linguistic competence of military professionals, future officers' foreign language training is of particular importance. This requires a substantial updating of the content and search for the most effective forms and methods of the educational process at higher military educational institutions in order to ensure a sufficient level of cadets' foreign language knowledge, effective interaction in the system «teacher-cadetborderguard» in order to find ways of cooperation in the field of security and defense reformation, competitiveness and integration into the modern world.

We find its effectiveness in the key and regulatory role of the teacher as the subject of the educational process management. Recognition of this position initiates increased researchers' attention in the field of educational psychology to the personality of the teacher of the higher military educational institution in general and his emotional intelligence, emotional 
competence in particular. As the professional activity of the teacher belongs to the «man-man» interaction sphere and is related to the interaction both with the study group as a whole and with interpersonal interaction with the subjects of studying. In view of this, it can be argued that the importance of the emotional competence of such a specialist is essential to ensure the success of his professional activity.

The purpose of the study is to theoretically and empirically investigate the role of teacher's emotional competence in subject-subject interaction with future officers-borderguards in foreign language learning environment.

The object of the study is the joint foreign language learning activity process of a teacher and future officers-borderguards at a higher military educational institution.

The subject of the study is the teacher's emotional competence development in subject-subject interaction with future officers-borderguards in foreign language learning environment.

According to the purpose, object and subject of the study, the main tasks are defined: to analyze the existing conceptual approaches to the study of the problem; to investigate the notion of emotional competence of the foreign language teacher of a higher military educational establishment; to define the psychological features of the teacher and cadets-borderguards' interaction in the joint foreign language learning activity process ; to highlight the results of empirical and experimental results focused on foreign language learning effectiveness at a higher military educational institution.

To solve the problems identified in the study, the following methods have been applied: theoretical methods (the study and analysis of scientific literature, comparison, generalization, systematization of scientific sources to determine the state of development of the research problem; empirical methods - psychological and pedagogical experiment: observation, questioning, testing (Hall test for determining the level of emotional intelligence).

\section{The concept of emotional competence in contemporary psychology}

The study of this phenomenon is a new segment in the personality emotional sphere research. The expediency of studying emotional competence is conditioned by the importance of emotions in one's life and human activity in general ${ }^{1}$ (O. Lazurenko, 1997).

It is widely recognized that emotions are included in all person's mental processes and states; they accompany any manifestations of his activity.

${ }^{1}$ Lazurenko O.O. (1997) Emotsii i yikh znachennia v zhyttiediialnosti liudyny [Emotins and their meaning in person's life activity]. Kyiv. [in Ukrainian]. 
A wide range of emotions indicates significant potential for an emotional factor $^{2}$ (K. Izard, 1980).

Theoretical analysis made it possible to generalize the results of different authors' researches by the level of structure and development of theoretical conceptions of the studied phenomenon. In general, the fundamental theoretical and experimental studies are highlighted in the psychological and pedagogical literature, they relate to the patterns of the emotional sphere formation, general aspects of the problem of emotions, emotional maturity etc.

In the psychological and pedagogical literature the problem of psychological culture of personality is revealed in the works of G. Ball, M. Bastun, I. Ziaziun, O. Ignatovich, V. Panchenko, P. Perepelytsia, E. Pomytkin, V. Rybalki, Z. Stanovsky, N. Chepeleva and others; formation patterns of the emotional sphere, general aspects of the problem of emotions, emotional maturity are grounded in the works of G. Breslav, O. Zaporozhets, O. Kulchytska, A. Olshannikov, A. Sukharev, O. Chebykin, O. Yakovleva and others.), emotional intelligence is studied by R. Bar-On, D. Goleman, D. Caruso, D. Liusin, J. Mayer, P. Salovey and others.

O. Bondarenko, S. Maksimenko, M. Tomchuk, T. Shcherban and other scientists consider the content of the teacher's psychological competence at a higher military educational institution, taking into account the peculiarities of his professional socialization. Some peculiarities of the professional activity of a foreign language teacher in a higher military educational institution are considered in the works of O. Volobuyeva, N. Gotsulyak, O. Grinchyshyn, O. Voityuk and others. However, there are still a lot of open questions regarding the improvement of the teacher's psychological competence, in particular the teacher of a foreign language in the process of subject-subject interaction at a higher military educational institution, regarding the question of his emotional intelligence and emotional competence. First of all, we set out to investigate these issues within the context of subject-subject interaction in the «teacher - future officerborderguard «system in the process of mastering a foreign language.

It is worth noting that the theoretical and methodological approaches to the problem of correlation of the intellectual and the emotional were considered in the works by B. Ananiev, L. Vygotsky, S. Rubinstein, O. Leontiev, V. Myasyshchev, O. Tikhomirov and others. Well-known psychologists V. Viliunas pointed to the close connection of thinking, intelligence and emotional processes. Some of them emphasized that with all the importance of intellectual comprehension and world cognition, emotions

\footnotetext{
${ }^{2}$ Izard K. (1980) Emocii cheloveka [Man's Emotions]. M. [in Russian].
} 
and feelings determine the main line of human behavior (V. Viliunas, B. Dodonov, K. Izard, O. Luk, P. Simonov and others).

Further study of emotions came at the end of the last century, when the concepts of «emotional intelligence» and «emotional competence characterizing the ability to manage emotional phenomena and properties appeared. It has led to an intensive increase in the number of scientific publications aimed at studying these phenomena.

T. $\operatorname{Komar}^{3}$ (T. Komar, 2014, p. 6) states that "people are not only socially but also emotionally and psychologically connected to each other. The quality of human life depends to a great extent on the relationship with other people, on the feelings and cravings felt by man. All this is exacerbated by the fear of loss or circumstances in which these relationships take different forms - from confrontation, remoteness, when only dependence, affinity, trust, and various forms of attachment are associated with another person».

In our time, the growing interest of scientists in the study of human emotions is the emergence of trends in the use of categorical concepts such as emotional thinking, emotional giftedness, emotional creativity, emotional regulation, emotional maturity emotional reasoning ${ }^{4}$ (E. Nosenko, 2000), emotional self-awareness ${ }^{5}$ (O. Vlasova, 2005).

In modern psychological and pedagogical theories emotion is considered as a special type of knowledge ${ }^{6}$ (E. Yakovleva, 1997).

The notion of emotional competence is a later formation than emotional intelligence. The concept of emotional intelligence emerged as a term in the psychological literature with the release of the famous Howard Gardner's monograph «Frames of mind» in 1983. Gardner suggested that there is not one single type of intelligence that influences the success of human life in a

${ }^{3}$ Komar T.V. (2014) Sotsialno-psyhologichnyi prostir yak chynnyk profesiinoii zrilosti osobystosti [Social and psychological space as a factor of personality professional maturity] [Електронний ресурс] Visnyk Natsionalnoi akademii Derzhavnoi prukordonnoi sluzhby Ukrainy - Scientific works collection of National academy of the State Border Guard Service of Ukraine- Issue 2. - Retrieved from: http://nbuv.gov.ua/UJRN/Vnadps_2014_2_17. [in Ukrainian].

${ }^{4}$ Nosenko E. L., Kovryga N. V. (2000) “Emotsiina rozumnist” iak determinant uspishnoi zhyttiediialnosti liudyny I shliahy iioperatsionalizatsii [Emotional reasonability as a factor of successfulperson's life activity and the ways of its operanalization]. Visnyk Dnipropetrovskogo Universytetu [Herald of the Dnipropetrovsk University. - Pedagogy and Psychology. - Issue. 6.

${ }^{5}$ Vlasova O. I. (2005) Psyhologia sotsialnyh zddibnostei: structura, dynamika, chynnyky rozvytky: monografia [Psychology of social abilities: structure, dynamics, development factor: Monograph]. K.: Vydavnycho-poligrafichnyi tsentr "Kyivskyi Universytet". Publishing center "Kyiv University". [in Ukrainian].

${ }^{6}$ Yakovleva E. L. (1997) Emotsionalnyie mehanismy lichnosnogo i tvorcheskogo razvitia [Emotional mechanisms of personal and creative development]. Voprosy psihologii. Psychology Issues. - No 4. [in Russian]. 
certain way, but rather a sufficiently wide range of subtypes of intelligence with seven major variants of these subtypes. His list of subtypes of intelligence included: verbal, logical, mathematical, spatial, kinetic, musical and emotional types of intelligence ${ }^{7}$ (E. Nosenko, n. Kovryga, 2003). The latter was divided by Gardner into two further subtypes: intrapersonal and interpersonal ones. Interpersonal type characterizes a person's ability to interact with other people. Intrapersonal intelligence involves the ability of a person to self-actualize in the life, to motivate oneself for intensive activity in order to achieve success.

In recent years, there have been many publications in which researchers have substantiated a more detailed definition of the concept of emotional intelligence. Mayer and Salovey's research works offer a more detailed interpretation of the components of emotional intelligence, which can be considered as a further development of understanding of the concept of emotional intelligence proposed by psychologist Gardner.

The free encyclopedia Wikipedia presents emotional intelligence as a group of mental abilities involved in the awareness and understanding of person's own emotions and those of other people. People with high level of emotional intelligence have a good understanding of their emotions and feelings of others, can effectively manage their emotional sphere, and therefore in society, their behavior is more adaptive and they achieve their goals in interaction with others more easily.

According to the R. Bar-On's theory, emotional intelligence is defined as a set of diverse abilities that provide the opportunity to act successfully in any situation. The scientist identified 5 subcomponents that characterize the structure of emotional intelligence: self-understanding (awareness of own emotions, self-confidence, self-actualization); communicative potential (empathy, social responsibility); adaptive abilities (ability to overcome difficulties, emotional lability); antistress potential (self-control); optimism.

In Wikipedia a summary table showing the relationship of the structure of emotional intelligence with its functions is provided. The structure contains the following abilities: cognitive (provide interpretive function); emotional abilities (regulatory function); adaptive abilities (adaptive and stress-protective functions); social abilities (activating function,

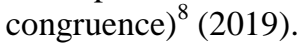

\footnotetext{
${ }^{7}$ Nosenko E. L., Kovryga N.V. (2006) Emotsiinyi intellect: kontseptualizatsia fenomeny, osnovni funktsii : monografia. [Emotional intelligence: phenomenon conceptualization, main functions: monograph]. - Vyshcha shkola. Higher School. [in Ukrainian].

8 Free Encyclopedia (2019). Retrieved from: https://uk.wikipedia.org/wiki/ Емоційний_інтелект.
} 
Today, there is not much research into the phenomenon of emotional competence. These are some works by D. Goleman, P. Salovey, K. Saarney, J. Mayer, M. Reynolds D. Goleman, K. Saarny, G. Breslav, I. Andrieeva, E. Nosenko and others. This problem is actively discussed and developed in the works of G. Garskova, D. Lusina, M. Manojlova and other psychologists. The analysis of the scientific and methodological literature shows that among the researchers of emotional competence there is no unambiguous opinion regarding the definition of this concept, its content, structure, as well as the factors that determine its development.

Recently, researches of Ukrainian scientists on the problems of emotional competence studying, its structure and functions appear: works by I. Arshava, O. Vlasova, S. Derev'yanko, N. Kovryga, E. Lazurenko and others. These researchers view emotional competence as a universal tool for success in all life spheres, and the result of high emotional competence is the ability to manage own emotions and the process where those emotions develop. It significantly expands the problems of research, attracts new thoughts, developments, methods, allows to compare traditional approaches with the latest, to comprehend domestic experience in the context of the world. That is why, in our deep conviction, it will be appropriate to study in detail the the emotional competence content in the frame of subject-subject interaction in the foreign language learning environment at a military educational institution. The problem of emotional intelligence has become quite popular and, therefore, we'd like to take a fresh look at the content of the emotional sphere of the individual as a whole. After all, the problems we are exploring are of great interest in the strategies of organizing and implementing subject-subject interaction in the conditions of mastering a foreign language.

\section{The content of emotional competence in subject-subject interaction in foreign language learning process at a higher military educational institution}

Interaction is characterized as social, group activity, human impact on the individual, as a multilevel phenomenon in which cooperation is distinguished as the highest level of interaction ${ }^{9}$ (A. Leontiev, 2001).

One of the important aspects of interaction is its «psychology», that is, the attitude towards another person. We consider interaction as a process of influence of subjects on each other, characterized by the emergence of connections, interdependence and mediation of their joint activity or

9 Leontiev A. N. (2001) Dieiatelnost. Soznanie. Lichnost. [Activity. Consiuosness. Personality] - M. [in Russian]. 
communication. Interaction takes two forms: communication and joint activity (although their separation is to some extent relative, since joint activity cannot be realized without elements of communication and in turn, communication often acts as a component or means of joint activity), we use the category interaction that reflects processes of communication and collaborative activities as well ${ }^{10}$ (V. Hrishko-Dunaievska, 2017). Communication is the interaction of two or more people, consisting of the information exchange of cognitive or affective-evaluative nature. B. Lomov described the category of communication as the essential aspect of human being - interaction at the level of subject-subject communication ${ }^{11}$ (B. Lomov, 1981).

A number of scientists, examining the psychological problems of interaction between the subjects of the pedagogical process, identified the characteristic features of different parties of communication, emphasizing, in particular, the role of their specific psychological characteristics, especially such characteristics as psychological and pedagogical observation, depth of empathy, accuracy of social perception ${ }^{12}$ (K. Dubovyi, 2012).

The psychologist T. Shcherban in her research reveals the content of such kind of communication, which realizes the ability of the teacher and the student to relationship, as educational communication, substanyiating it as a special kind of relationship between (among) people (which not only transfers knowledge, but also develops the aspirations and skills independently to acquire new knowledge, new experience) as a process of collaboration between the teacher and the student, in which this form of interaction is based on active feedback, which organizes, regulates and enriches each of this process participants ${ }^{13}$ (T. Shcherban, 2004).

The structure of educational communication, from the point of view of the researcher, is characterized by the unity of external, behavioral, operative-active side and internal, deep one, which includes motivational

${ }^{10}$ Hrishko-Dunaievska V. A. (2017) Osobluvosti subiekt-subiektnoi vzaiemodii v protsesi vyvchennia inozemnoi movy $u$ vyshchyh viiskovyh navchalnyh zakladah [Peculiariyies of subject-subjekt interaction in the foreign language learning process at higher military educational institution] (PHD Thesis in "Pedagogic and Age psychology": specialty 19.00.07). Khmelnytskyi. (NASBSU) [in Ukrainian].

${ }^{11}$ Lomov B. F. (1981) Problema obshcheniia v psihologii [Problem of communication in psychology] - M.: Science. [in Russian].

${ }_{12}$ Dubovyi K. V. (2012) Psyhologichni umovu rozvytku komunikatyvnyh $i$ kognityvnyh komponentiv inshomovnyh zdibnostei studentiv [Psychological conditions of development of students' communicative and cognitive foreign language abilities] PHD Thesis in "Pedagogic and Age psychology": specialty 19.00.07. - Khmelnytskyi: NASBGSU publ. [in Ukrainian].

${ }^{13}$ Shcherban T. D. (2004) Psyhologia navchalnogo spilkuvannia: monografia [Psychology of study communication]: monograph. - K.: Millenium. [in Ukrainian]. 
and semantic, value characteristics and emotional and empathic capabilities of the personality and plays a decisive, determinative role.

V. Sukhomlynskyi emphasizes the need to establish such relationships between the teacher and students, which can be characterized as spiritual community, mutual trust, openness, kindness. Therefore, when addressing the teachers, he emphasizes that it is necessary to master the art of empersonation, the art of active emotional and intellectual complicity with the subjects of studying process ${ }^{14}$ (V. Sukhomlynskyi, 1974).

Our study would not be complete without a theoretical analysis of the approaches of scientists to the essence of subject-object and subject-subject interaction. Communication, including pedagogical, implemented on the basis of «subject-object» principles, where only one partner acts in the full role of the subject, while the other partner is assigned the role of a simple object of influence and manipulation. This, in particular, is the communication on the principle of orders, commands, schoolings, etc. The same types include common cases of dominance of one of the partners, asymmetry of the parties to the communication, the desire to assert the priority of one of the interlocutors, ignoring its sovereignty and independence, as well as cases of mistrust and desire to approve a single and 'indisputable' point of view; selfishness and rigidity in communication when for one reason or another communication does not take on the role of genuine dialogue but remains monologous. The emotional aspects of human interaction are also ignored. Another approach ${ }^{15}$ (S. Batrakova, 1986) in the teacher-cadets relationship is characterized as subject-subject connection. In this case, the teacher proceeds from the fact that the student appears or should act as a «living person expressing emotions», a communicating subject. Therefore, within the subject-subject pedagogical communication there is a transfer of positive knowledge, because communication takes place on the interpersonal emotional level, not on the inter-personal level, as in the subject-object style.

According to this model, pedagogy of cooperation, polysubjective approach, personal oriented interaction is developed. In this case, both the teacher and the cadet are recognized as equal subjects of pedagogical interaction. They have a certain freedom in designing their own activity, a characteristic feature of which is the ability to make independent choices, to realize their «I». The main contradictions are solved by cooperation, not by coercion. Relationships are built on a realistic basis of mutual acceptance

${ }^{14}$ Sukhomlynskyi V. A. (1974) Serdtse otdaiu dietiam [Give my heart to the children]. 5-th issue. - K.: Radianska shkola. Soviet Shcool. [in Russian].

${ }^{15}$ Batrakova S. N. (1986) Osnovy professional-pedagogicheskogo obshchenia [Principles of pedagogical communication] - Yaroslavl: Yar. state. university. [in Russian]. 
and understanding, and therefore everyone has the opportunity to be individual. Self-realization of the teacher's personality is a prerequisite for self-realization of the student and vice versa, successful personal growth of the student is an incentive for the development of the teacher's personality ${ }^{16}$ (I. Bulakh, 2002), ${ }^{17}$ (V. Patiushkin, 1984). The emotional component as well is the ability to respond spiritually, which is indisputably important for the subject-subject interaction ${ }^{18}$ ( I. Bekh, 1998, p. 125).

According to psychologist I. Postalovsky ${ }^{19}$ (I. Postalovskyi, 1999, p. 66), "co-operative interaction means that the teacher and the student work together. The fundamental condition for subject-subject interaction is to give the partner the right to choose his or her behavior. And, at the same time, it is necessary to encourage him to share emotions in a pedagogically appropriate direction. Teacher, acting as a mentor, facilitator, initiator of interaction, the result of which depends on whether the student agrees to participate in the collaboration, whether he accepts the offered assistance or make the appropriate choice.

We can state that all conceptual approaches to determining the subjectsubject interaction of the educational process indicate the presence and importance of the emotional component, which confirms the right vector of our research. This problem becomes even more important when we understand that the specifics of the educational process of a higher military educational establishment are determined predominantly by an authoritarian (strictly regulated) system of educational process management, which is based on statutory relations, which influences the implementation of any type of activity of a future officer-bordergurd. In spite of the presence of scientific works in which the emotional sphere of the personality is investigated, it is necessary to pay attention to the lack of studies of the emotional competence of socionomic spheres professionals and psychological and pedagogical conditions of its development in the process of foreign language teaching at higher military educational institutions and, as as a result, to the absence of a consistent, thorough approach to managing this process.

${ }^{16}$ Bulakh I. S., Dolynska L. V. (2002) Psyhologichni aspekty mizhosobystisnoi vzaiemodii vykladachiv $i$ studenti: navch. metod. posib. [Psychological aspects of interpersonal interaction of teachers and students: methodical textbook]. - K.: NPU named after Drahomanov. [in Ukrainian].

${ }^{17}$ Patiushkin V. P. (1984) Funktsyi $i$ formy sotrudnichestva uchitelia $i$ uchashchihsia $v$ uchebnoi dieiatelnosti [Functions and forms of interaction of the teacher and students in learning activity]: PHD Thesis in Psychology. [in Russian].

${ }^{18}$ Bekh I. D. (1998) Osobystisno-zoriientovane vyhovannia: nauk. metod. posibnyk [Personality-oriented education: scient.- method. textbook]. - K.: IZMN. [in Ukrainian].

19 Postalovskyi I. (1999) Trenirovka intensivnogo slushania [Training of intensive listening]. - Odessa: Reclamservise. [in Russion]. 
Therefore, it is extremely important for the teacher at a military institution to acquire a high level of emotional competence to be able to properly organize and implement subject-subject interaction in order to provide effective foreign language teaching to cadets-bordergurds.

Our study takes into account the characteristics of educational groups of a higher military educational institution, which have not only common for any other study group social and psychological features, but also specific ones, which are caused by the tasks defined by the higher military educational institution, the nature of the cadets' daily activities. Cadets are not only to study, but also execute military service, fulfilling all elements of military service. Having examined its activity specificity, we find such features as the follows: uniformity of age structure of educational groups members, their merger into a single educational process; relative stability, duration and continuity of interaction and intensity of communication of all its members; relatively high level of self-government; the presence of sufficiently strict relations regulation and functional dependence of the group members determined by the system of subordination; observance of military discipline and order; uniformity in complex jointly coordinated activities etc.

Today, it should be understood that the teacher faces a challenge in organizing subject-subject interaction in foreign language classes, because it is necessary to take into account the emotional request of the entire study group and to establish a favorable psychological atmosphere. The difficulty is that today young people who entered the military institution are not only after secondary school education, but also those who have some experience of serving in the Joint Forces Operation zone in the east of Ukraine. This aspect leads to the search and development of new methods, approaches and algorithms for working in groups with different background cadets. And the task of the foreign language teacher in this case is to resort to such an organization of interpersonal interaction, which should unite the training group as a whole and actualize all possible levers of emotional influence for the development of motivation for mastering a foreign language and overcoming the psychological barriers that create paralyzing conditions in a joint foreign language activity.

In the conditions of higher military educational institutions, the emotional competence of the teacher, who can use his entire professional arsenal in creating a favorable psychological climate, plays a particularly important role. The teacher should not dominate the audience, but seek to engage the learning subjects with the communication process, enabling them to interact with others, creating the conditions for the development of their self-awareness and self-regulation. The role of the teacher as an interlocutor puts him on an equal footing with those who are being taught, which helps to eliminate the psychological barriers between them, eases the stress during 
the class, creates more free conditions for communication $^{20}$ (O. Hrynchyshyn, 2003, p. 137-138). In this context, the teacher's personality and his emotional competence play a crucial role in the teaching process. O. Fuhelo, examining the indicators of work satisfaction at the stage of professional formation of military personnel, found that the social and psychological climate of the military group largely depends on the commander of the unit. He argues that the major drawbacks of officers' training are their poor awareness of the problems of managing the spiritual processes, emotions and values of military units. The author argues that commanders who have subordinates do not always have the high level of skills to work with them. This leads to psychological discomfort for all participants in the service and education process. "When comparing the levels of cadets' service (training, studying) satisfaction, it was found that in those companies where the commander's style of work is based not on the humanity laws but only on giving orders, these levels were lower by 1.4-1.8 times» $^{21}$ (O. Fuhelo, 2004, p.87).

Foreign language, as a subject of teaching, reveals powerful resources for the development of professional competence of future military specialists. O. Volobuieva ${ }^{22}$ (O. Volobuieva, 2010, p.36) also emphasizes that "the peculiar psychological nature of a foreign language as an educational subject influences all the mental processes of the cadet: the peculiar features are characterized by the processes of feeling and perception; high foreign language memory requirements; plays a particularly complex and peculiar role in foreign language thinking; the feelings and emotions associated with learning a foreign language are quite peculiar; special requirements are placed by the teaching of a foreign language to the cadets and students' attention and will».

The professional personality formation is a complex process of interaction between intellectual and emotional development. Such components of the emotional sphere of personality as emotional stability,

${ }^{20}$ Hrynchyshyn O.M. (2003) Rozvytok motyvatsii ovolodinnia inizemnoiy movoiu v umovah vyshchogo viiskovogo navchalnogo zakladu [Motivation development of a foreign language learning in the conditions of a higger military educational institution]. PHD Thesis in Psychology : 19.00.09. - Khmelnytskyi: NADPSU Publishing. [in Ukrainian].

${ }^{21}$ Fuhelo O. M. (2004) Otsinka, kryterii ta pokaznyky zadovolenosti pratseiu na etapi profesiinogo stanovlennia viisovosluzhbovtsiv [Evaluation, criteria and indicators of work satisfaction at the stage of serviceman's professional formation]. Zbirnyk naukovyh prats № 26. Chastyna II. Collection of scientific works № 26. Part II. - Khmelnytskyi: Publ. NASBGSU. [in Ukrainian].

22 Volobuieva O. F. (2010) Psyhologichni zasady rozvytku profesiinyh inshomovnyh zdibnostei maibutnioho viiskovogo profesionala [Psychological principles of professional foreign languages abilities of future military professional]: diss. ...doctor of psychol. sciences; The G. S. Kostiuk Institute of Psychology NAPN of Ukraine. [in Ukrainian]. 
emotional self-regulation, emotional intelligence and emotional competence in whole, are not less important than the mental, social, intellectual spheres.

We consider the emotional competence of a foreign language teacher of a higher military educational institution as a component of professional competence and as a set of abilities and skills to achieve the ultimate goal in joint foreign language interaction with future military professionals taking into account the subject- subject interaction criteria in the condition of strict military subordinative structure. The teacher exhibits a high level of self-awareness, selfmanagement, social awareness, relationship management etc.

We found interesting for our study the workout of I. Matiikiv ${ }^{23}$ (I. Matiikiv, 2013, p. 146-147). The psychologist defines the emotional competence criteria of socionomic specialist which included: life position, level of subjective control, management of emotions (basic emotional competences), type of thinking (positive, negative), type of motivation, reflexive skills, self-esteem, communicative potential, type of behavior. These criteria and their indicators are the basis for developing the structure of emotional competence and levels of its formation. Having defined two levels (low and high), reflecting the qualitative structure of emotional competence formation process, the researcher attributes to them certain psychological characteristics (Fig. 1).

Selected emotional competence criteria by I. Matiikiv overlap with the criteria of subject-subject interaction, which we have studied in our research: the criterion of self-regulation, the criterion of social comfort, predictive criterion which reflect the attitude of subjects of education to the ability to change the level of self-identity in the process of interaction with teachers and create a desire to get engaged in the learning process and a willingness to change their minds, estimation, judgments, attitudes, and this is not accompanied by negative emotions etc. Such a comparison proves that the hypothesis of our study is valid and has grounds for further study ${ }^{24}$ (V. Hrishko-Dunaievska, 2011).

23 Matiikiv I. (2013) Emotsiina kompetentnist iak psyhologichnyi obiekt vyhovannia osobystosti maibutniogo fahivtsia profesii typu "liudyna-liudyna" [Emotional competence as psychological object of education of future specialist of "man-man" type profession]. Pedagogika i psyhologiia osvity. Pedagogy and psychology of Education. №2. Retrieved from: http://lib.iitta.gov.ua/6156/1/Pippo_2013_2_19.pdf [in Ukrainian].

${ }^{24}$ Hrishko-Dunaievska V. A., Volobuieva O.F. (2011) Kryterii efektyvnosti subiekt0subiektnoi vzaiemodii u navchalno0vyhovnomu protsesi pry vyvchenni inizemnoi movy u VVNZ: psyhologichnyi aspect [Criteria of subject-subject interaction effectiveness in educational process while learning a foreign language at a higher military educational institution: psychological aspect]. Visnyk Natsionalnogo universytetu oborony Ukrainy: zbirnyk. nauk. prats. za red. Stasiuka V. V. Heald of scient. works in red. Of Stasiuk V.V.- K.: NUOU. Issue. 6 (25). [in Ukrainian]. 
Criteria: life posture by Harris; level of subjective control (external and internal); time competence; managing emotions (basic emotional competencies); type of thinking; type of motivation; reflexive skills; self-esteem; communicative potential; type of behavior

\begin{tabular}{|l|}
\hline \multicolumn{1}{|c|}{ Low level } \\
\hline - irresponsibility for the events \\
of own life, which is perceived \\
as a consequence of external \\
factors; \\
- distortion of reality perception, \\
a focus on the past or the future; \\
-insufficient process of \\
observing emotions and \\
analyzing them; \\
- low behavior self-control; \\
- internal tension, lack of living \\
emotions;
\end{tabular}

- inability to use the techniques

of psychophysiological self-

regulation;

- uncontrollable outburst of emotions by the mechanism of conditioned reflex;

- the tendency to constantly pessimistic thinking, focusing on the problem, not the way to solve it;

- low tolerance to situations of failure;

- motivation to avoid failure instead of setting yourself up for success; - low level of self-knowledge skills development;

- avoidance of honest and open relations, which determines the formality of the relationship; - inattention to other people's emotional state; - misunderstanding of the importance of non-verbal communication component; - protective, rigid behavior

- a life-affirming attitude to oneself and own surroundings;

- responsibility for own emotions and life in general;

- the adequacy of the sense of reality and its objective perception;

- analysis and understanding of emotional experiences causes;

- management and control of the emotional experiences intensity;

- ability to motivate yourself and others;

-expression of emotions and feelings on verbal and nonverbal levels, use of other means of emotional expression adequate to the situation and social and cultural norms; - possession of techniques of psychophysiological selfregulation;

- the ability to choose from a wide range of possible emotional reactions at a particular moment one that will help to work and interact with people effectively; - optimistic thinking, developed sense of humor, cheerfulness, energy;

- self-confidence, especially in unfamiliar situations, in the face of uncertainty;

- achievement motivation, mobilization of forces and focus on goal achievement; striving for self-knowledge, development and self-improvement, own potential realization;

- adequate self-esteem;

- the ability to establish and maintain emotionally supportive and comfortable relationships;

- ability to identify (recognize, understand) the emotions of other people, to analyze the causes of their occurrence, - sympathize (empathy) and provide emotional support;

- ability to active listening, to constructive feedback;

- openness and tolerance to those views and opinions

that differ from the own ones;

- ability to be congruent; assertive behavior;

a wide range of emotional responses, the ability to change their plans when circumstances require

\section{Fig. 1. Psychological characteristics of levels of emotional competence} of the individual by I. Matiikiv

\section{Experimental study of foreign language teachers' emotional intelligence levels at the NASBGSU (N. Hall Emotional Intelligence Test)} Although researchers view the structure of emotional competence differently, they all emphasize that emotional competence is the individual's 
motivational and energy resource and it manifests itself as a factor and indicator of personality development, his or her psychological well-being and mental health.

For this reason, we have addressed the teachers of the English Language and Translation Departments (in number of 28 persons) of the National Academy of the State Borderguard Service of Ukraine named after B. Khmelnytsky (hereinafter - NADPSU) with the request to answer the N. Hall Emotional intelligence Test ${ }^{25}$ (D. Raihorodskyi, 2002). N. Hall's test for determining the level of emotional intelligence is based on a mixed model of emotional intelligence and constructed as a questionnaire that demonstrates the ability to understand the relationship represented in emotions and to manage the emotional sphere on the basis of decisions. This technique contains 30 statements. The test involves the evaluation of 5 components of emotional intelligence: emotional awareness, managing one's emotions, self-motivation, empathy, coaching others' emotions. The response scale is six-step type. The teachers were required to write a number to the right of each statement based on their stage of agreement with it: Disagree very much (-3 points); disagree moderately ( -2 points); disagree slightly ( -1 point); agree slightly $(+1$ point); agree moderately ( +2 points); agree very much $(+3$ points). The points are calculated with the help of a pre-prepared «key», the positive and negative answers are calculated. Score is determined by a custom table. The results determine the level of partial emotional intelligence according to the sign of the results, i.e. definite strength (high), needs some development (average), need substantial development (low) levels. The integrative level of emotional intelligence is determined separately, taking into account the dominant sign. The author identifies three levels of emotional intelligence on each of the scales: need substantial development level (7 and less), need substantial development level (8-13) and definite strength level (14 or more points).

The results of the study of the levels of partial emotional intelligence are graphically shown in Fig. 2-6.

${ }^{25}$ Raigorodskyi D. Ia. (2002) Prakticheskaia psihidiagnostika. Metodiki i testy: uchebnoie posobiie [Practical Psychodiagnostics. Methodics and tests. Textbook]. Samara: Publishing House BAHRAH-M. [in Russian]. 


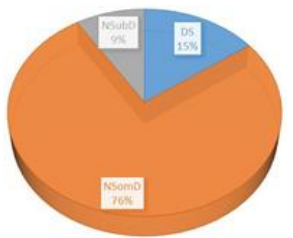

Fig. 2 Coaching others'emotions

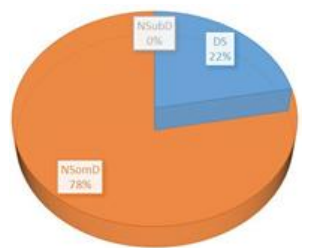

Fig 3. Emotional awareness

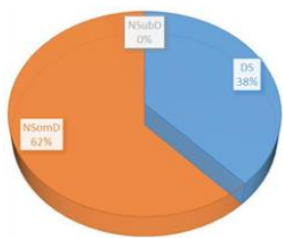

Fig 4. Managing one's emotions

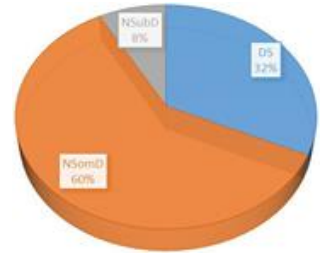

Fig. 5 Self-motivation

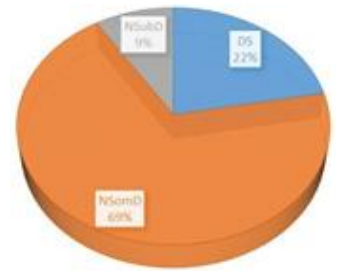

Fig. 6 Empathy

Figures 2-6 show that in the scales of «emotional awareness» and «managing one's emotions» foreign language teachers are above average (78\% and 62\% respectively), but what is important that these two scales did not reveal low levels of these abilities; while other scales namely «empathy» (high-22\%, average-69\%, low 9\%), "self-motivation» (high-32\%, average$60 \%$, low- $8 \%$ ), «coaching others' emotions» (high-15\%, average-76\%, low $9 \%$ ) are in average level dominantly, but testing has shown a presence of low percentage of these emotional intelligence abilities.

Thus, these data indicate that there are problematic aspects that need further development. On an empathy testing scale, we can state that foreign language teachers are able to empathize with another person's emotional state, to support them, understand and accept the feelings and emotions of others, to put themselves in other's place in a variety of situations, and can also provide an emotional assessment actions and to teach cadets, that is, to develop the capacity for empathy - to accept those feelings that someone else is experiencing, as if they were their own. But the low percentage indicates the possibility of starting conflict and difficulties in finding compromise solutions in non-standard situations.

The results of testing on "coaching others' emotions» scale appeared to be a problematic aspect, which is especially important for foreign language teachers of military higher education in iteraction with cadets. Psychology of military discipline and subordination itself teaches to suppress the cadets' true feelings and emotions, but it is essential to create a favorable emotional 
climate in the study group for introduction into a foreign language environment, and the teacher is to see, recognize and coach the cadets' true emotions. Then it is possible to solve the problem at the stage of its birth, to eliminate psychological paralyzing barriers that neutralize and inhibit all psychological principles of creating conditions for mastering a foreign language.

The results on the scale of «self-motivation» show that foreign language teachers are positively motivated professionals, show a willingness to successfully pursue a professional activity, produce new, original ideas, stay initiative, carry out a creative search. But in order to reorient an individual's behavior to his/her internal reserves and motivated efforts, it is necessary to synthesize into a single system the best methods, modern techniques, conduct a self-work, promote the opportunities for enhancing one's own activity for professional and personal success.

The high and average percentages of the «managing one's emotions» and «emotional awareness» scales demonstrate a sufficient level of tested competence. The teachers are aware of their inner state. In managing their emotions, they have sufficient emotional flexibility and skillful management of their emotions, they are capable of congruence and self-competence; have assertive behavior; have a wide range of emotional responses, the ability to change their plans when circumstances require, and to interact with future border guards in joint foreign language activities.

The results of the study of the levels of development of integrative emotional intelligence of foreign language teachers are shown in Figure 7.

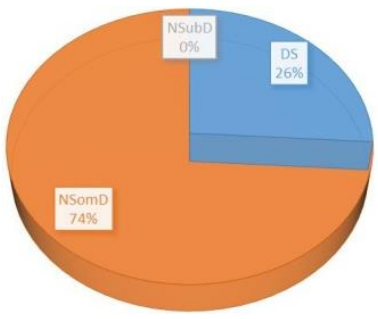

Fig. 7

Analyzing the test results of the levels of development of the integrative emotional intelligence of foreign language teachers of NADPSU, we can say that the average level $(74 \%)$ is dominant here and the high level have a significant percentage $(26 \%)$. The lack of low level of development of emotional intelligence demonstrates that the foreign language teachers of NASBGSU provide a psychological basis for the development of positive, 
partnership, equal relations, which create the conditions for the implementation and organization of subject-subject interaction in the joint foreign-language activity of members of the training group, mutual cognitive emotional reflection, anticipation, etc. The ability to take responsibility and control one's own actions is an indicator of the emotional and social maturity of a professional. An emotionally competent teacher is able to create a favorable psychological microclimate to eliminate the psychological barriers that facilitate the tensions of the military atmosphere of strict subordination that is inherent in all military structures. We can state the emotional stability of the teacher and his/her affiliation with the subject, in particular, the benefits of indirect managerial influence on the study group as a whole and on each cadet; the teacher's consideration of communication partners (cadets) expectations for professional activity; a high degree of positive motivation of the learning activities of the subjects of study, their interest in learning a foreign language for further effective professional activity at the border under special conditions; direct interaction between the subjects of the educational process and mutual satisfaction with productive foreign language cooperation.

\section{CONCLUSIONS}

To sum up, theoretical analyses of the conceptual approaches to the notion of emotional intelligence in contemporary psychology have been conducted to define that emotional intelligence is considered as a set of diverse abilities (cognitive, emotional, adaptive, social) that provide the opportunity to act successfully in any situation. Its structure includes selfunderstanding (awareness of own emotions, self-confidence, selfactualization); communicative potential (empathy, social responsibility); adaptive abilities (ability to overcome difficulties, emotional lability); antistress potential (self-control); optimism.

However, the complex profession of the teacher requires constant selfimprovement, and as it has been confirmed in our study, the emotional competence of the teacher emerges as a complete and progressive development of the emotional sphere of the individual and represents a set of knowledge, skills and abilities that allow to act adequately on the basis of the profession of the whole information. Emotional competence enriches the experience of the individual, provides a quick analysis of emotional situations. That is why emotional competence can and should act as one of the basic aspects of forming a foreign language teacher's personality. But the identified problematic aspects of the study of the levels of partial emotional intelligence of foreign language teachers in the scales of «Empathy» and «Coaching others' emotions» and "Self-Motivation" require further substantial development in these areas, with the aim of establishing honest 
and frank relationships, which weakens the formality of the relationship of subordination and status coordination; increases the level of attention to the emotional state of others, understanding the importance of the non-verbal component of communication; changes protective, rigid behavior to assertive one, displaying flexibility in managing emotional reactions, thoughts, and behaviors according to communicative situations and conditions that change in joint foreign language learning activity etc.

Perspective way of further research is development and implementation of efficient methods and techniques of improving emotional competence components, namely to work out a social and psychological training of emotional competence for the teachers of foreign language at the higher military educational instituon.

\section{SUMMARY}

The article deals with revealing the role of the teacher's emotional competence in subject-subject interaction in foreign language learning process taking into account the features of the higher military educational istitution. The emotional competence of a foreign language teacher of a higher military educational institution is considered as a component of professional competence and as a set of abilities and skills to achieve the ultimate goal in joint foreign language interaction with future military professionals taking into account the subject- subject interaction criteria in the condition of strict military subordinative structure.

The emotional competence criteria have been defined: life position, level of subjective control, management of emotions (basic emotional competences), type of thinking (positive, negative), type of motivation, reflexive skills, self-esteem, communicative potential, type of behavior. Experimental study (N. Hall Emotional Intelligence Test) of the foreign language teachers' emotional intelligence levels at the NASBGSU has been conducted and some problematic aspects have been revealed: three scales («empathy» (high-22\%, average-69\%, low 9\%), «self-motivation» (high$32 \%$, average-60\%, low-8\%), «coaching others' emotions» (high-15\%, average-76\%, low 9\%) are dominantly in average level, but testing has shown a presence of low percentage of these emotional intelligence abilities and they need further substantial development and working out.

\section{REFERENCES}

1. Batrakova S. N. (1986) Osnovy professional-pedagogicheskogo obshchenia [Principles of pedagogical communication] - Yaroslavl: Yar. state. university. [in Russian]. 
2. Bekh I. D. (1998) Osobystisno-zoriientovane vyhovannia: nauk. metod. posibnyk [Personality-oriented education: scient. - method. Textbook]. - K.: IZMN. [in Ukrainian].

3. Bulakh I. S., Dolynska L. V. (2002) Psyhologichni aspekty mizhosobystisnoi vzaiemodii vykladachiv $i$ studentiv: navch. metod. posib. [Psychological aspects of interpersonal interaction of teachers and students: methodical textbook]. - K.: NPU named after Drahomanov. [in Ukrainian].

4. Dubovyi K. V. (2012) Psyhologichni umovu rozvytku komunikatyvnyh $i$ kognityvnyh komponentiv inshomovnyh zdibnostei studentiv [Psychological conditions of development of students' communicative and cognitive foreign language abilities] PHD Thesis in "Pedagogic and Age psychology": specialty 19.00.07. - Khmelnytskyi: NASBGSU publ. [in Ukrainian].

5. Free Encyclopedia (2019). Retrieved from: https://uk.wikipedia.org/ wiki/Емоційний_інтелект [in Ukrainian].

6. Fuhelo O. M. (2004) Otsinka, kryterii ta pokaznyky zadovolenosti pratseiu na etapi profesiinogo stanovlennia viisovosluzhbovtsiv [Evaluation, criteria and indicators of work satisfaction at the stage of serviceman's professional formation]. Zbirnyk naukovyh prats № 26. Chastyna II. Collection of scientific works № 26. Part II. - Khmelnytskyi: Publ. NASBGSU. [in Ukrainian].

7. Hrishko-Dunaievska V. A. (2017) Osobluvosti subiekt-subiektnoi vzaiemodii $v$ protsesi vyvchennia inozemnoi movy $u$ vyshchyh viiskovyh navchalnyh zakladah [Peculiariyies of subject-subjekt interaction in the foreign language learning process at higher military educational institution] (PHD Thesis in "Pedagogic and Age psychology": specialty 19.00.07). Khmelnytskyi. (NASBSU) [in Ukrainian].

8. Hrishko-Dunaievska V. A., Volobuieva O.F. (2011) Kryterii efektyvnosti subiektOsubiektnoi vzaiemodii u navchalno0vyhovnomu protsesi pry vyvchenni inizemnoi movy $u$ VVNZ: psyhologichnyi aspect [Criteria of subject-subject interaction effectiveness in educational process while learning a foreign language at a higher military educational institution: psychological aspect]. Visnyk Natsionalnogo universytetu oborony Ukrainy: zbirnyk. nauk. prats. za red. Stasiuka $V$. V. Heald of scient. works in red. Of Stasiuk V.V.- K.: NUOU. - Issue. 6 (25). [in Ukrainian].

9. Hrishko-Dunaievska V. A., Volobuieva O.F. (2011) Kryterii efektyvnosti subiektOsubiektnoi vzaiemodii u navchalno0vyhovnomu protsesi pry vyvchenni inizemnoi movy u VVNZ: psyhologichnyi aspect [Criteria of subject-subject interaction effectiveness in educational process while learning a foreign language at a higher military educational institution: psychological aspect]. Visnyk Natsionalnogo universytetu oborony Ukrainy: 
zbirnyk. nauk. prats. za red. Stasiuka $V$. V. Herald of scient. works in red. Of Stasiuk V.V.- K.: NUOU. - Issue. 6 (25). [in Ukrainian].

10. Hrynchyshyn O.M. (2003) Rozvytok motyvatsii ovolodinnia inizemnoiy movoiu $v$ umovah vyshchogo viiskovogo navchalnogo zakladu [Motivation development of a foreign language learning in the conditions of a higger military educational institution]. PHD Thesis in Psychology: 19.00.09. - Khmelnytskyi: NADPSU Publishing. [in Ukrainian].

11. Izard K. (1980) Emocii cheloveka [Man's Emotions]. M. - 440 p. [in Russian]

12. Komar T.V. (2014) Sotsialno-psyhologichnyi prostir yak chynnyk profesiinoii zrilosti osobystosti [Social and psychological space as a factor of personality professional maturity] [Електронний pecypc] Visnyk Natsionalnoi akademii Derzhavnoi prukordonnoi sluzhby Ukrainy Scientific works collection of National academy of the State Border Guard Service of Ukraine- Issue 2. - Retrieved from: http://nbuv.gov.ua/UJRN/Vnadps_2014_2_17. [in Ukrainian].

13. Lazurenko O.O. (1997) Emotsii $i$ yikh znachennia $v$ zhyttiediialnosti liudyny [Emotins and their meaning in person's life activity]. Kyiv. [in Ukrainian].

14. Leontiev A. N. (2001) Dieiatelnost. Soznanie. Lichnost. [Activity. Consiuosness. Personality] - M. [in Russian].

15. Lomov B. F. (1981) Problema obshcheniia v psihologii [Problem of communication in psychology] - M.: Science. [in Russian].

16. Matiikiv I. (2013) Emotsiina kompetentnist iak psyhologichnyi obiekt vyhovannia osobystosti maibutniogo fahivtsia profesii typu "liudynaliudyna" [Emotional competence as psychological object of education of future specialist of "man-man" type profession]. Pedagogika i psyhologiia osvity. Pedagogy and psychology of Education. № 2. Retrieved from: http://lib.iitta.gov.ua/6156/1/Pippo_2013_2_19.pdf [in Ukrainian].

17. Nosenko E. L., Kovryga N. V. (2000) "Emotsiina rozumnist" iak determinanta uspishnoi zhyttiediialnosti liudyny $i$ shliahy iioperatsionalizatsii [Emotional reasonability as a factor of successfulperson's life activity and the ways of its operanalization]. Visnyk Dnipropetrovskogo Universytetu [Herald of the Dnipropetrovsk University. - Pedagogy and Psychology. - Issue. 6.

18. Nosenko E. L., Kovryga N.V. (2006) Emotsiinyi intellect: kontseptualizatsia fenomeny, osnovni funktsii: monografia. [Emotional intelligence: phenomenon conceptualization, main functions: monograph]. Vyshcha shkola. Higher School. [in Ukrainian].

19. Patiushkin V. P. (1984) Funktsyi i formy sotrudnichestva uchitelia $i$ uchashchihsia $v$ uchebnoi dieiatelnosti [Functions and forms of interaction 
of the teacher and students in learning activity]: PHD Thesis in Psychology. [in Russian]

20. Postalovskyi I. (1999) Trenirovka intensivnogo slushania [Training of intensive listening]. - Odessa: Reclamservise. [in Russion].

21. Shcherban T. D. (2004) Psyhologia navchalnogo spilkuvannia: monografia [Psychology of study communication]: monograph. - K.: Millenium. [in Ukrainian].

22. Sukhomlynskyi V. A. (1974) Serdtse otdaiu dietiam [Give my heart to the children]. - 5-th issue. - K.: Radianska shkola. Soviet Shcool. [in Russian].

23. Vlasova O. I. (2005) Psyhologia sotsialnyh zddibnostei: structura, dynamika, chynnyky rozvytky: monografia [Psychology of social abilities: structure, dynamics, development factor: Monograph]. K.: Vydavnychopoligrafichnyi tsentr "Kyivskyi Universytet". Publishing center "Kyiv University". [in Ukrainian].

24. Volobuieva O. F. (2010) Psyhologichni zasady rozvytku profesiinyh inshomovnyh zdibnostei maibutnioho viiskovogo profesionala [Psychological principles of professional foreign languages abilities of future military professional]: diss. of ...doctor of psychol. sciences; The G. S. Kostiuk Institute of Psychology NAPN of Ukraine. [in Ukrainian].

25. Yakovleva E. L. (1997) Emotsionalnyie mehanismy lichnosnogo $i$ tvorcheskogo razvitia [Emotional mechanisms of personal and creative development]. Voprosy psihologii. Psychology Issues. - No 4. [in Russian].

Information about the author: Valentyna Hrishko-Dunaievska, Candidate of Psychological Science, Senior Instructor of the English Language Department, NASBGS of Ukraine, 46 Shevchenko str., Khmelnytskyi, Ukraine, 29000 ORCID ID: orcid.org/ 0000-0001-5365-0355 valentine999@ukr.n 


\section{SOCIO-PSYCHOLOGICAL ANALYSIS OF CONTENT AND STRUCTURE OF COMMUNICATIVE COMPETENCI ES OF BORDERGUARD CADETS}

\section{Halyna Topolnytska}

\section{INTRODUCTION}

The fundamental theoretical basis for interdisciplinary research in the problems of personality development and formation, to which the culture of interpersonal relations belongs, is the provision on the human social essence. The personality crystallizes in own psychological structure of social relations, and at the same time personality. becomes their object and subject.

The category of «relationship» becomes the «common territory, a subject that belongs at the same time to both psychology and ethics.» S. Rubinstein noted that relationships are «the core of real-life psychology», «the realm of the» intersection «of psychology with ethics» ${ }^{1}$ (Rubinshtein, 1989). Using the category of relations as the basic one, one should pay attention to the concept of relations V. Myasishchev, who characterized the study of relations as «... an important approach in psychology, which combines the objective with the subjective, external with internal» ${ }^{2}$ (Miasishchev, 1995a). From this point of view, the relationship as a subject-subject relationship is not only a socio-psychological but also a cultural category, that is, in the phenomenon of relations, the unity of psychological and social is realized.

The concept of relations of V. Myasishchev foresees at least four points when analyzing the phenomenon of "relationship" itself. Firstly, this is the need for another, in which V. Myasishchev understood «... the cognitive tendency to master another person $»^{3}$ (Miasishchev, 1995b). This is a distinction between two basic needs: the need for communication and the need for co-operation.

Secondly, it is an interest in the other as an «active emotional-cognitive attitude to another person.»

The scientist distinguished two types of interest: interest in the personal sphere, that is, experiences, feelings and unique originality and interest in the

${ }^{1}$ Rubinshtein S.L. (1989). Osnovy obshchei psikhologii. V 2 t. T. 1 [Fundamentals of General Psychology. In 2 vols. Vol. 1]. Moscow: APN USSR. P. 328. [in Russian].

${ }^{2}$ Miasishchev V.N. (1995). Psikhologiia otnoshenii [Psychology of relations]. Moscow. 229 p. [in Russian].

${ }^{3}$ Miasishchev V.N. (1995). Psikhologiia otnoshenii [Psychology of relations]. Moscow. 229 p. [in Russian]. 
intellectual sphere of personality. Thirdly, it is an emotional attitude to another. According to V. Myasishchev, it «... manifests in affection, love, sympathy and their opposites - hostility, obscurity, antipathy» ${ }^{4}$ (Miasishchev, 1995c). And finally, fourthly, is the evaluation relationship, which the scientist defined as «The process of comparison of actions and deeds with samples» ${ }^{5}$ (Miasishchev, 1995d).

Interpersonal relationships, both objectively experienced and to a different degree by conscious relationships between people, are closely linked to different types of social interactions. «Interpersonal relationships within different forms of social relations are the direct realization of impersonal relationships in the activities of particular individuals, in the acts of their communication and interaction» ${ }^{6}$ (Naprasna, 2004). Thus, the culture of interpersonal relationships is thus a reflection of the socio-cultural situation in the country, region, State Border Guard Service of Ukraine, etc. and confront the socio-cultural situation as a single with the general, and the problem research of the culture of cadets interpersonal relationships, and from a psychological point of view seems quite reasonable.

\section{Psychological analysis of communicative competencies content of border guard cadets}

Considering the culture of interpersonal relationships as a result of reflecting the impact of the macro environment on each subject of interaction, it is necessary to distinguish several sociocultural characteristics of communicative competence that change as the environment changes. These characteristics, which are described in cross-cultural psychology as cultural syndromes, are essentially tools for the psychological dimension of culture. Among the main cultural features are «individualism collectivism», «simplicity - complexity», «openness - closedness» of the collective culture ${ }^{7}$ (Buzin, 1992).

Without doing a detailed analysis of each of the syndromes of «individualism - collectivism», «simplicity - complexity», «openness -

\footnotetext{
${ }^{4}$ Miasishchev V.N. (1995). Psikhologiia otnoshenii [Psychology of relations]. Moscow. 229 p. [in Russian].

${ }_{5}^{5}$ Miasishchev V.N. (1995). Psikhologiia otnoshenii [Psychology of relations]. Moscow. 229 p. [in Russian].

6 Naprasna O.B. (2004). Indyvidualno-psykholohichni osoblyvosti kohnityvno-stylovykh kharakterystyk navchalnoi diialnosti studentiv: Dys... kand. psykhol. nauk [Individual-psychological features of cognitive-style characteristics of students' educational activity: Dis ... Cand. psych. sciences]. Kyiv: The Taras Shevchenko National University of Kyiv. P. 188. [in Ukrainian]

${ }^{7}$ Buzin E. V. (1992). Mezhlichnostnoe ponimanie kak faktor effektivnosti uchebnoprofessionalnoi deiatelnosti gruppy kursantov Avtoref dis kand psikhol nauk [Interpersonal understanding as a factor in the effectiveness of educational and professional activities of a group of cadets: Author's abstract. diss. psych. sciences]. Kyiv. P. 22 [in Russian].
} 
closedness» of culture, let us note only that the communicative competencies of cadets-border guards will be considered within the basic dimension of cultural variability, namely in dimension «Collectivism-individualism». The expediency of such consideration of interpersonal relations is determined by at least two circumstances: the first is based on the results of those ethnopsychological researches that classify our Slavic culture to collectivist-type cultures, and, secondly, the significance given in the domestic sociopsychological phenomena such as «social-psychological unity», «cohesion», «disunity», «compatibility», which are the essence of the psychological theory of the collective ${ }^{8}$ (Topolnytska, 2006).

Although the essence of the differences in the collectivist and individualistic nature of communicative competences has been studied for over a hundred years, no systematic experimental studies have been conducted in this direction. However, analyzing interpersonal relationships and knowing the results of their psychological knowledge abroad, as well as summarizing the idea of communicative competencies of domestic researchers, we try to uncover the features of interpersonal relationships that have a collectivist and individualistic orientation (Table 1.1).

Based on the analysis of scientific sources, the main sociocultural categories, which are, on the one hand, forms of culture, and on the other forms of mental reflection of the subject-cultural world, are knowledge, norm, social model and value. The complexity of these categories requires a separate psychological analysis. But, in one way or another, these categories have basic cultural functions, namely:

streamlining the common life of many people by structuring their social experience;

providing meaningful orientation to any social processes (formation of meaningful constructs of social actions);

ensuring the continuity of generations through their socialization through providing individuals with value-normative coordinates of behavior and norms-prohibitions, frameworks, ideals.

${ }^{8}$ Topolnytska H. Yu. (2006). Zmina sotsialnykh ustanovok i vplyv kolektyvnopsykholohichnykh umov na formuvannia kultury mizhosobystisnykh vidnosyn v kursantskykh kolektyvakh [Changing social attitudes and the influence of collective-psychological conditions on the formation of a culture of interpersonal relations in cadets] // Zbirnyk naukovykh prats. Natsionalnoi akademii DPSU [Published by the National Academy of the SBGS of Ukraine]. P. 134. [in Ukrainian]. 
Table 1.1

\section{Comparison collectivist and individualistic orientationin interpersonal relationships}

\begin{tabular}{|c|c|c|}
\hline $\begin{array}{l}\text { Characteristic of } \\
\text { interpersonal relationships }\end{array}$ & $\begin{array}{l}\text { Collectivist } \\
\text { orientation of } \\
\text { interpersonal relations }\end{array}$ & $\begin{array}{l}\text { Individualistic } \\
\text { orientation of interpersonal } \\
\text { relations }\end{array}$ \\
\hline $\begin{array}{l}\text { The basis is the various } \\
\text { emotional states of interacting } \\
\text { people and their psychological } \\
\text { characteristics }\end{array}$ & $\begin{array}{l}\text { The advantage of } \\
\text { conjunctive affective } \\
\text { experiences }\end{array}$ & $\begin{array}{l}\text { Various emotional states of } \\
\text { interacting people and their } \\
\text { psychological peculiarities }\end{array}$ \\
\hline $\begin{array}{l}\text { Elements } \\
\text { - cognitive component; } \\
\text { - affective component; } \\
\text { behavioral component. }\end{array}$ & $\begin{array}{l}\text { The advantage of } \\
\text { positive behavioral } \\
\text { reactions }\end{array}$ & $\begin{array}{l}\text { The advantage of indifferent } \\
\text { and disjunctive affective } \\
\text { experiences; - the } \\
\text { advantage of indifference, } \\
\text { negative behavioral } \\
\text { reactions }\end{array}$ \\
\hline $\begin{array}{l}\text { Dynamics: } \\
\text { - dating; } \\
\text { - friendly relations; } \\
\text { - social relations; } \\
\text { - hearty relations } \\
\end{array}$ & $\begin{array}{l}\text { Dynamic features of } \\
\text { development do not } \\
\text { differ in a degree of } \\
\text { expressiveness }\end{array}$ & $\begin{array}{l}\text { Concentration on a large } \\
\text { number of dating and } \\
\text { friendships based on the } \\
\text { balance of mutual services }\end{array}$ \\
\hline $\begin{array}{l}\text { The main mechanism of } \\
\text { Development: } \\
\text {-empathy: } \\
\text { cognitive empathy; } \\
\text { emotional empathy; } \\
\text { - effective empathy }\end{array}$ & $\begin{array}{l}\text { Expressiveness of } \\
\text { emotional and acting } \\
\text { empathy in relationships }\end{array}$ & $\begin{array}{l}\text { The advantage of cognitive } \\
\text { empathy; Emotional and } \\
\text { acting are much less } \\
\text { common }\end{array}$ \\
\hline $\begin{array}{l}\text { Levels: } \\
\text { 1) business } \\
\text { 2) game } \\
\text { 3) manipulative } \\
\text { 4) spiritual } \\
\text { 5) primitive } \\
\text { 6) conventional }\end{array}$ & $\begin{array}{l}\text { Relationships take } \\
\text { priority at the spiritual } \\
\text { level, which determines } \\
\text { the degree of } \\
\text { functionality of other } \\
\text { levels }\end{array}$ & $\begin{array}{l}\text { The advantage of business, } \\
\text { manipulative and } \\
\text { conventional relations }\end{array}$ \\
\hline $\begin{array}{l}\text { Forms of interaction: } \\
\text { Collaboration - cooperation; } \\
\text { Adjustment - coordination } \\
\text { conformality; } \\
\text { Competition - rivalry; } \\
\text { Subcontracting - } \\
\text { subordination; } \\
\text { Confrontation - conflict. }\end{array}$ & $\begin{array}{l}\text { Interaction is based on } \\
\text { co-operation, } \\
\text { coordination and } \\
\text { subordination of } \\
\text { conformality }\end{array}$ & $\begin{array}{l}\text { Interaction based on } \\
\text { competition, counteraction, } \\
\text { conventionality }\end{array}$ \\
\hline
\end{tabular}

One of the decisive factors that influences the culture of interpersonal relationships, in addition to knowledge and norms, is the social model.

The social model - is a living example that embodies certain values, norms and knowledge in relationships. The regulation of public life itself is based not so much on verbal-pronounced demands, but on specific examples of the implementation of these cultural precepts. The ability to imitate is 
inherent in each person, it has its own mechanism of implementation (reference groups, leadership). The same psychological mechanism serves the process of generation and functioning of social models ${ }^{9}$ (Yahupov, 2000].

Such categories as "norm", "social model" and "values" are categories of both intrapersonal and interpersonal interaction that have a socio-cultural character (Table 1.2).

Table 1.2

\section{Forms of culture and forms of subject-cultural world mental reflection}

\begin{tabular}{|c|c|}
\hline Forms of culture & $\begin{array}{c}\text { Forms of mental reflection } \\
\text { subject-cultural world }\end{array}$ \\
\hline Knowledge & Cognitive processes \\
\hline Norm & Attitude to the norms and their implementation \\
\hline Social sample & $\begin{array}{c}\text { Identification, imitation, emotional-volitional, evaluation } \\
\text { comparison with the sample }\end{array}$ \\
\hline Value & Meaning and sense \\
\hline
\end{tabular}

A cultural norm is a system of behavioral expectations, cultural perceptions of how people envision or attempt to act. In social terms, the norm puts certain demands on the individual, shapes the expected behavior, understandable to other people.

Cultural norms include:

a) a collective assessment of what the behavior of a representative of a particular culture should be;

b) collective interpretation of what this or that behavior means;

c) personal reactions to behavior, including attempts to impose sanctions on "undesirable" behaviors.

A set of norms constitutes a normative culture that is carefully designed and established in the form of customs, moral rules, institutional regulations, and is a system of standardized, expected means of feeling and action ${ }^{10}$ (Zazhyrko, 1998).

${ }^{9}$ Yahupov V.V. (2000). Upravlinski funktsii ofitsera ta yikh pedahohichnyi zmist [The managerial functions of the officer and their pedagogical content] // Visnyk AU pry Prezydenti Ukrainy [Bulletin of the AU under the President of Ukraine]. Vyd-vo UADU. Vol. 2. P. 307. [in Ukrainian].

${ }_{10}$ Zazhyrko M.P. (1998). Hlybynnopsykholohichni peredumovy aktyvizatsii protsesu spilkuvannia (akmeolohichnyi pidkhid): Dys... kand. psykhol. Nauk [Deep-psychological preconditions for activating the communication process (acmeological approach): Dis ... Cand. Psych. Sciences]. Cherkasy: Cherkasy State University named after B. Khmelnytskyi. P. 47. [in Ukrainian]. 
The culture of communicative competences of cadets is essentially institutionalized because it is defined and enshrined in the form of social norms, rules, that is, acts as a system that satisfies socially approved goals ${ }^{11}$ (Yahupov, 2004). The normative relations of servicemen are defined by the Military Regulations of the Ukrainian Armed Forces, other governing documents and establish a clear framework of their behavior, set the motives and evaluation criteria for certain actions. A notable feature of normative relationships is that, first, they have detailed regulation that relies on legal acts and, secondly, are characterized by «impersonality» because they target all servicemen ${ }^{12}$ (Safin, 1997).

One of the decisive factors influencing the culture of interpersonal relations, in addition to knowledge and norms, is the social model.

The social model - is a living example that embodies certain values, norms and knowledge in relationships ${ }^{13}$ (Leontev, 1971). The regulation of public life itself is based not so much on verbal and spoken demands, but on specific examples of the implementation of these cultural precepts. The ability to imitate is inherent in each person, it has its own mechanism of implementation (reference groups, leadership). The same psychological mechanism serves the process of generation and functioning of social models. One of these examples of interpersonal relationships for cadets is often their own co-workers or direct or direct commanders (bosses). It is their behavior, especially with regard to human relationships, that becomes the object of careful attention and evaluation of successors.

Knowledge, norms and social models, which are in the mind of the cadet in themselves, are only a set of rules where there is no place for the subjective and personal. Social models as knowledge are differ from norms as values. An exclusively value-based, research-based culture is a kind of social mechanism that identifies, coordinates, addresses, reproduces, preserves, protects, develops and transmits values in society ${ }^{14}$ (Bodalev, 1993). In the psychological tradition, values as such are viewed because of the problem of complementarity of meanings and senses. At the same time values are called «relatively stable, socially conditioned, selective attitude of

11 Yahupov V.V. (2004). Viiskova psykholohiia: Pidruchnyk [Military Psychology: Textbook]. Kyiv: Tandem. P. 156. [in Ukrainian].

12 Safin O.D. (1997). Psykholohiia upravlinskoi diialnosti komandyra: Navchalnyi posibnyk [The psychology of managerial activity of the commander: Study Guide]. Khmelnytskyi: Publishing House of the PVU Academy. P. 149 [in Ukrainian].

${ }^{13}$ Leontev A.N. (1971). Potrebnosti, motivy, emotsii [Needs, motives, emotions]. Politizdat. P 79. [in Russian].

14 BodalevA.A. (1993) Psihologija mezhlichnostnyh otnoshenij (k 100-letijuso dnja rozhdenija V.N. Mjasishheva). [Psychology of interpersonal relations (to the 100th anniversary of the birth of V.N. Mjasishheva)]. //Voprosy psihologii. -№2. - 86s. [in Russian] 
the person to the set of material and spiritual public goods, ideals, which are the objects of goals and means for meeting the needs of the vital activity of the individual».

According to S. Rubinstein, it is in human activity to meet immediate public needs that the social scale of values is manifested. At satisfaction of personal and individual needs by means of socially useful activity the attitude of the person to society is realized, and hence the comparison of personal and socially significant.

In this regard, the scientist emphasizes that «... values are not primary. They do not need to begin analysis: they are derived from the juxtaposition of the world and person, they reveal what is in the world, encompassing what creates person in the process of history. Value is the significance of something for a person in the world. Such values are an ideal for her - an idea whose meaning expresses something more meaningful" ${ }^{15}$ (Rubinshtein, 1989).

Psychological content of value orientation was investigated by A. Zdravomyslov by studying her attitude to work. Under the value orientations he understood "the setting of personality on certain values of material and spiritual culture of society.

Value orientations - the most important component of the structure of personality, which in a unique way summarizes the whole life experience, accumulated personality in his individual development. They are a component of personality structure, that is, a certain axis of consciousness, around which the thoughts and feelings of a person revolve, and on which many vital questions are determined." A. Zdravomyslov thought that it is the value orientations as the most important component of the structure of personality that determine his behavior and attitude to the outside world, and therefore this concept is very close to the concepts used in psychology «setting», «need» and «interest» ${ }^{16}$.

In addition, the scientist gave a functional definition of value orientations - «regulation of behavior as a conscious action under certain social conditions.»

The main socio-psychological problem associated with the acquisition and development of knowledge, norms and social models, which are expressed in the value orientations of the individual, is the complementarity of psychoformations in the inner world of the individual. The point is that in the personality, including the personality of the cadet, not all possessed

${ }^{15}$ Rubinshtein S.L. (1989). Osnovy obshchei psikhologii. V 2 t. T. 1 [Fundamentals of General Psychology. In 2 vols. Vol. 1]. Moscow: APN USSR. P 337. [in Russian]

${ }^{16}$ Zdravomyslov A.G. 1964. Potrebnosti. Interesy. Tsennosti. [Needs. Interests Values.]. Leningrad: Publishing House of Leningrad State University. P. 89. [in Russian] 
knowledge and norms become regulators of behavioral activity, and therefore actions can develop in two directions:

a) «I know that there are such norms, but I act on the principle of expediency» - this knowledge is defined, but not filled with personal meaning;

b) «I know that there are such norms and I am acting in accordance with them» - this knowledge becomes important.

Thus, the culture of interpersonal relationships manifests itself at two levels - at the level of competence in relationships and at the level of the relationship culture. Most often, the research uses the concept of «communicative competence», «competence in communication», which in the most general terms «involves the development of an adequate orientation of the person in themselves - their own psychological potential, the potential of a partner, in the situation.» However, the formation of communicative competence is mainly aimed at acquiring the «technique» of communication, the ability to maintain interpersonal contacts and, using optimal behavioral strategies, to achieve their goals in communication.

In the present day, psycho-communication becomes an important feature in which the automatic transfer of utilitarian behavior to what might be sincere communication takes place, and then only contact means remain from communication. In other words, sometimes by «technology», «transactions», «transituational learning» the moral meaning, the awareness of the humanistic side of personal interaction is lost.

According to G. Batishchev, the concept of «deep communication» can also be described as true cultural communication: after all, «oncommunication» is inherent only to deep culture, while «psychocommunication» is a civilization, an extra-moral, technocratic world. From this, we can assume that the culture of relationships in this tradition should be understood as a value that is realized through maximum openness and sincerity in communication, empathy, and identification with a significant other $^{17}$ (Batishchev, 1987).

\section{Theoretical analysis of the essence of culture of interpersonal relations}

At the same time as the perception of existing relationships and understanding (acceptance or non-acceptance) of socially approved rules and

${ }^{17}$ Batishchev G.S. (1987). Dialektika obshcheniia: gnoseologicheskie i mirovozzrencheskie problemy: Sb nauch tr [Dialectics of communication: epistemological and ideological problems: Collection of Scientific Works] // Institut filosofii AN SSSR [Institute of Philosophy, USSR Academy of Sciences]. Ed. by G. S. Batishchev, B.I. Pruzhinin. Moscow. P. 56. [in Russian]. 
norms, their assessment takes place, which, in turn, leads to regulation and self-control of their behavior. Emotion-volitional aspects are based on at least three grounds: first, on the individual-psychological characteristics of the individual, first of all, his temperament; second, the importance of the value of the particular situation of the subject; third, the situational experiences associated with the most important cognitive components that can act as «operators» in relation to the emotional components of individual social settings. However, depending on the peculiarities of the situation (tense, free, provides information, does not provide it) and the characteristics of the subject (rational or emotional type), you can expect different options for the manifestation of emotional and volitional actions of the subject. Therefore, the culture of interpersonal relationships includes a second, emotional-volitional component that assesses interpersonal relationships and social norms, regulates the behavior of the subject. This component is represented by the socio-psychological phenomena of empathy, self-control of behavior and emotional stability ${ }^{18}$ [(Antonova, 2013).

The result of mnemonic and mental operations on the perception and awareness of interpersonal relationships and emotional-volitional regulation of their behavior are changes in the needs-motivational sphere of the individual and his or her value orientations.

The basis of the whole system of human relations with the outside world is the set of his needs and motives.

This sphere of personality determines the selectivity and sets the system of readiness for action against different objects of the surrounding reality.

The necessity-motivational sphere as the primary determines the specificity of the value-orientation sphere of the individual and relates to it as general and special. The result of this correlation is the set of attitudes or dispositions, that is, the internal behavioral readiness, which, one way or another, is fixed in the personal structure.

Considering the orientation of the individual as a dynamic tendency, SL. Rubinstein asserted that every dynamic tendency, expressing the directionality of a person, always involves a more or less conscious connection of the individual with something outside him, the relationship of internal and external. In the possibility of reversibility of this relationship between the importance of purpose and desire, the will is the most specific and peculiar trait of human orientation and the tendencies that create it.

18 Antonova N.O. (2003). Tsinnisni oriientatsii u systemi osobystisnykh rys studentiv vyshchoho pedahohichnoho navchalnoho zakladu: dys... kand. psykhol. nauk [Valuable orientations in the system of personality traits of students of higher pedagogical institution: Psych. Sciences Thesis]. Kyiv: Institute of Psychology of the Academy of Pedagogical Sciences of Ukraine named after G.S. Kostyuk. [in Ukrainian] 
One such trend stands out as a special moment is installation. "The establishment of the individual, according to SL Rubinstein, is a position taken by him that is in relation to the set goals or tasks and is expressed in the electoral mobilization and readiness for activities aimed at their realization ${ }^{19}$ (Rubinshtein, 1989).

A.V. Petrovsky argued that no researcher of the problem of activity can get past the theory of installation. The core of scientific research and the main emphasis in the conceptual understanding of the installation are to indicate the dependent nature of the subject's activity from the existing installation, that is, a person's willingness to perceive the world in a certain way, to act in one direction or another ${ }^{20}$ (Petrovsky, 1989).

Thus, the set of previously entrenched, and thus culturally conditioned attitudes, the disposition to one or another behavior and relationships, which are based on the need-motivational and value formation of the individual and will represent for us the essence of a culture of interpersonal relationships.

In this case, the cultural nature of relationships as a behavioral act is determined, first, by the degree of awareness and experience of interpersonal relationships, their relationship with the internal system of values, and second, by the mechanism of manifestation of the first, internal component through the ability to regulate emotional manifestations, volitional efforts in behavior. This ability, that is, the external manifestation of culturalism is considered through the manifestation of a respectful cadets' attitude to each other and conflict-free in interpersonal contacts.

In psychological science, several approaches to understanding the phenomenon of «culture of interpersonal relations» are developed, which in their essence mean a socially approved set of communicative competences.

In the psychological culture of relationships, he identifies three dependent components:

a) understanding and knowledge of self and other people;

b) adequate self-assessment and evaluation of other people;

c) self-regulation of personal states and properties of self-organization of activity, regulation of relationships with other people. At the same time, the basis of such a culture of relationships between people, according to M.V Savchin, is «knowledge of oneself and other people in all their diversity» ${ }^{21}$ (Savchyn, 1997).

${ }^{19}$ Rubinshtein S.L. (1989). Osnovy obshchei psikhologii. V 2 t. T. 1 [Fundamentals of General Psychology. In 2 vols. Vol. 1]. Moscow: APN USSR. P 337. [in Russian]

${ }^{20}$. Petrovsky A.V. (1998). Voprosy istorii i teorii psikhologii [Issues of history and theory of psychology]. Moscow. [in Russian]

${ }_{21}$ Savchyn M.V. (1997). Psykholohichni osnovy rozvytku vidpovidalnoi povedinky osobystosti: Dys... d-ra psykhol. nauk [Psychological bases of development of responsible 
It is worth noting that the process of understanding, adequate self-esteem and evaluation of other people is more about the psychological competence of the individual, rather than its cultural character in relationships. Relation of the content of the concepts of competence in relations and culture

First, the culture of interpersonal relationships is commonly considered to be part of the personality culture, it consists of three components cognitive (knowledge culture), activity (culture of creative interaction) and emotional-volitional (culture of feelings and communication).

Secondly, it is a qualitative correlation of these three components, which allows us to present in the study the levels of culture of interpersonal relations that are derived from the degree of correlation of these components.

Third, it is important to focus on the implementation of a culture of interpersonal relationships: on the one hand, on productive interference with social activities, and on the other, on self-regulation of affective manifestations and the attainment of emotional comfort.

Psychological culture contains a complex of actively realizing culturalpsychological aspirations and corresponding skills", namely:

a) systematic self-education of cultural aspirations and skills;

b) a fairly high level of ordinary and business communication;

b) appropriate mental self-regulation;

c) creative approach to business;

d) the ability to know and realistically evaluate their personality.

S.B.Koval views the psychological culture of the individual "as a systemic multicomponent formation. In his opinion, it can be revealed from the point of view of the following basic aspects: epistemological, procedural-activity, subjective-personal”22 (Koval, 2011).

Corporate interaction is a form of realization of psychological personality culture and acts as:

system of specific human activities;

set of spiritual values;

the process of self-realization of the creative essence of man

This view of the phenomenon of culture, in our view, allows us to distinguish the parameters of the diagnosis of culture of interpersonal relationships, namely:

personality behavior: Dis ... Dr. psych. Sciences]. Kyiv: Institute of Pedagogy and Psychology of Professional Education of the Academy of Pedagogical Sciences of Ukraine. P. 374. [in Ukrainian].

${ }^{22}$ Koval S.B. (2001). Psykholohichni chynnyky rozvyvalnoi komunikatyvnoi sytuatsii u vyshchykh zakladakh osvity: Dys... kand. psykhol. Nauk [Psychological factors of developmental communicative situation in higher educational establishments: Dis ... Cand. psych. Sciences]. Ivano-Frankivsk: Vasyl Stefanyk Carpathian University. P. 136. [in Ukrainian] 
psychological literacy of interpersonal relationships;

psychological competence in interpersonal relationships;

value-semantic component of interpersonal relations;

the ability to reflect and cultivate in the sphere of interpersonal interaction.

Given that the main form of communication competencies is the process of communication, analysis of communication culture should also be done through a culture of interpersonal relationships. The culture of interpersonal communication is, firstly, a means of communication between people, and secondly, the quality of communication of people at a certain stage of social development. " to analyze the levels of culture of such communication by taking into account the knowledge, the ability to use its means of communication, and also to observe the relevant norms ${ }^{23}$.

The general characteristics of the analyzed culture of interpersonal relationships are certainly realized through special, specific, specific environmental conditions, a social environment characterized by a number of features:

the nature of leading activities determines a special system of relationships, which is based, on the one hand, on the rigid regulation of all life, and, on the other, on the selectivity and variability of creating interpersonal dyads, triads, etc.;

homogeneity and relative age homogeneity of the cadets subdivisions defines and brings in the interpersonal relations of cadets high significance of ideals of youth subculture, which is not always identical with the ideal idea of the defender of the Motherland, criteria of honor, decency in relations, etc .;

Thus, the set of previously entrenched, and therefore, culturally predetermined, attitudes to one or another of the behaviors and attitudes that underlie the need-motivational and value formation of the individual, and can be called the essence of a culture of interpersonal relationships. This component, in its most general form, can be defined as another criterion of this culture, namely, a positive motivational system of relationships to a significant other.

23 Topolnytska H.Iu. (2011). Psykholohichni aspekty bazovykh tsinnostei moralnoi povedinky ofitsera-prykordonnyka [Psychological Aspects of Basic Values of Moral Behavior of Border Guard Officer] // Visnyk Natsionalnoi akademii Derzhavnoi prykordonnoi sluzhby Ukrainy : elektron. nauk. fakh. vyd. / hol. red. Hriaznov I. O [Bulletin of the National Academy of State Border Guard Service of Ukraine: electronic issue. Ed. Hriaznov I.O.]. Vol. 5. URL: http://www.nbuv.gov.ua/e-journals/Vnadps/2011_5/11tgupop.pdf [in Ukrainian]. 
In view of the fact that instructional behavior is only part of a more general psychological trait, in particular the personality orientation, it is necessary to proceed to the analysis of this element of the proposed scheme.

Obviously, orientation is based on a system of needs and motives that are inextricably linked to the value-oriented sphere of the individual. At the same time, it should be emphasized that the concepts of social setting can also trace the direct connection of value orientations with the specific need and conditions of activity in which this need can be satisfied. The change and fixing (fixation) of a social setting is also caused by the appropriate relationship between needs and situations in which they are met. The general scheme here is as follows: orientation - disposition - conditions of activity.

Dispositions are central to the scheme and central to the problematic culture of relations to the significant other. If they are a product of a «clash» of needs and situations in which the corresponding needs can be met and if they are fixed (fixed) in the personal structure, then it is natural to assume that these dispositional entities are formed into a certain system of dispositions, that is, into some culturally entrenched system of relations. The theoretical basis for considering the culture of interpersonal relationships through a system of dispositions is the dispositional concept of personality by V. Yadov ${ }^{24}$ (Yadov, 2000) (Table 1.4).

Table 1.3

The system of dispositions (by Yadov concept)

\begin{tabular}{|c|c|c|c|}
\hline Dispositions & Level of needs & Activity & Level of situations \\
\hline $\begin{array}{c}\text { Culture of } \\
\text { relations }\end{array}$ & Life goals & $\begin{array}{c}\text { System of value } \\
\text { orientations }\end{array}$ & $\begin{array}{c}\text { General social } \\
\text { conditions }\end{array}$ \\
\hline $\begin{array}{c}\text { A series of } \\
\text { actions }\end{array}$ & Personal interests & Basic social settings & Social spheres \\
\hline Act & Social need & $\begin{array}{c}\text { Social fixed } \\
\text { installations }\end{array}$ & Social situation \\
\hline Behavioral act & Greeting needs & $\begin{array}{c}\text { Elementary fixed } \\
\text { installations }\end{array}$ & Subject situation \\
\hline
\end{tabular}

It should be noted that according to developed by V. Yadov dispositional theory of personality, individual settings do not exist in a person by themselves, but are organized in the form of a certain hierarchical system of dispositions. The first (lower) level is elementary installations, which are formed on the basis of vital needs, and therefore are not characterized by modality; the second is the system of social attitudes (cognitive, emotional,

${ }^{24}$ Yadov V.Ya. (2000). Dispozitsionnaia kontseptsiia lichnosti [Dispositional concept of personality] // Sotsialnaia psikhologiia $v$ trudakh otechestvennykh psikhologov [Social psychology in the works of domestic psychologists]. St. Petersburg. 512 p. [in Russian] 
behavioral), occurring in individuals on the basis of specific social objects and situations; the third is basic social settings that determine the general orientation of human activity; the fourth - for the purpose of life and the means of achieving them. The behavioral system of the dispositional hierarchy is structured and reduced to a state of stable integrity, depending on the processes occurring in the cognitive, emotional spheres and in the personality orientation. At the same time, based on the research hypothesis, the cultural nature of relationships as a behavioral act can be determined, first, through the degree of awareness and experience of interpersonal contacts, their relation to the internal value system, and second, by the mechanism of manifestation of the first, internal component, ie ability to regulate emotional reactions, volitional efforts in behavioral acts.

Thus, the culture of interpersonal relationships in cadets is a qualitative and integral characteristic of relationships, since it involves both awareness of relationships as values, and regulation of their emotional-volitional feelings, and adequate behavior within socially significant and professionally valid norms and traditionally valid norms and traditions. and a specific kind of culture.

The external manifestation of the culture of these relationships is the set of behavioral acts that are the form and result of the presence of internal fixed installations that function in the unity of the cognitive and emotionalvolitional components in the general flow of personality orientation. The main criteria for the culture of interpersonal relationships are:

a) representation and understanding of established relationships;

b) emotional-volitional stability of relationships;

c) a positive motivational system towards others.

\section{CONCLUSION}

Summarizing the results of different approaches to the culture of interpersonal relationships, it is appropriate to highlight and note the general that combines approaches with each other and that is the basis for further consideration of the studied phenomenon of culture of interpersonal relationships. These summaries can be summarized in the following main points.

Communicative competence is a psychological phenomenon that has traits that can be recorded externally and that manifest themselves primarily in behavioral acts, as well as internal causes that lead to such behavior. Speaking of outward signs, it is a continuity of socially approved behavioral acts (instructive behavior) that are positively perceived by the vast majority of members of society. It is about the norms of politeness, respectful treatment of others, and the etiquette of relationships that are generally accepted in society. These external manifestations are generally evaluated in 
two dimensions - the dimension of the social, which defines the common component of the culture of interpersonal relationships, and the dimension of the stratometric, corporate, which, in addition to the general component, also covers some specific behavioral characteristics that a certain community (in our case, is a community ) will also be considered a cultural communicati Rubinshtein S.L. (1989 ve competence).

\section{REFERENCES}

1. Antonova N.O. (2003). Tsinnisni oriientatsii u systemi osobystisnykh rys studentiv vyshchoho pedahohichnoho navchalnoho zakladu: dys... kand. psykhol. nauk [Valuable orientations in the system of personality traits of students of higher pedagogical institution: Psych. Sciences Thesis]. Kyiv: Institute of Psychology of the Academy of Pedagogical Sciences of Ukraine named after G.S. Kostyuk. [in Ukrainian]

2. Bodalev A.A. (1993). Psihologija mezhlichnostnyh otnoshenij (k 100letijuso dnja rozhdenija V.N. Mjasishheva). [Psychology of interpersonal relations (to the 100th anniversary of the birth of V.N. Mjasishheva)]. //Voprosy psihologii. -№2. - 86s. [in Russian]

3. Buzin E. V. (1992). Mezhlichnostnoe ponimanie kak faktor effektivnosti uchebno-professionalnoi deiatelnosti gruppy kursantov Avtoref dis kand psikhol nauk [Interpersonal understanding as a factor in the effectiveness of educational and professional activities of a group of cadets: Author's abstract. diss. psych. sciences]. Kyiv. P.22 [in Russian]

4. Batishchev G.S. (1987). Dialektika obshcheniia: gnoseologicheskie $i$ mirovozzrencheskie problemy: Sb nauch tr [Dialectics of communication: epistemological and ideological problems: Collection of Scientific Works] // Institut filosofii AN SSSR [Institute of Philosophy, USSR Academy of Sciences]. Ed. by G. S. Batishchev, B.I. Pruzhinin. Moscow. P. 56. [in Russian]

5. Zazhyrko M.P. (1998). Hlybynnopsykholohichni peredumovy aktyvizatsii protsesu spilkuvannia (akmeolohichnyi pidkhid): Dys... kand. psykhol. Nauk [Deep-psychological preconditions for activating the communication process (acmeological approach): Dis ... Cand. Psych. Sciences]. Cherkasy: Cherkasy State University named after B. Khmelnytskyi. P. 47. [in Ukrainian]

6. Zdravomyslov A.G. 1964. Potrebnosti. Interesy. Tsennosti. [Needs. Interests Values.]. Leningrad: Publishing House of Leningrad State University. P. 89. [in Russian]

7. Koval S.B. (2001). Psykholohichni chynnyky rozvyvalnoi komunikatyvnoi sytuatsii u vyshchykh zakladakh osvity: Dys... kand. psykhol. Nauk [Psychological factors of developmental communicative situation in 
higher educational establishments: Dis ... Cand. psych. Sciences]. IvanoFrankivsk: Vasyl Stefanyk Carpathian University. P. 136. [in Ukrainian]

8. Leontev A.N. (1971). Potrebnosti, motivy, emotsii [Needs, motives, emotions]. Politizdat. P 79. [in Russian]

9. Miasishchev V.N. (1995). Psikhologiia otnoshenii [Psychology of relations]. Moscow. 229 p. [in Russian]

10. Naprasna O.B. (2004). Indyvidualno-psykholohichni osoblyvosti kohnityvno-stylovykh kharakterystyk navchalnoi diialnosti studentiv: Dys... kand. psykhol. nauk [Individual-psychological features of cognitive-style characteristics of students' educational activity: Dis ... Cand. psych. sciences]. Kyiv: The Taras Shevchenko National University of Kyiv. P. 188. [in Ukrainian]

11. Petrovsky A.V. (1998). Voprosy istorii i teorii psikhologii [Issues of history and theory of psychology]. Moscow. [in Russian]

12. Rubinshtein S.L. (1989). Osnovy obshchei psikhologii. V 2 t. T. 1 [Fundamentals of General Psychology. In 2 vols. Vol. 1]. Moscow: APN USSR. P 337. [in Russian]

13. Safin O.D. (1997). Psykholohiia upravlinskoi diialnosti komandyra: Navchalnyi posibnyk [The psychology of managerial activity of the commander: Study Guide]. Khmelnytskyi: Publishing House of the PVU Academy. P. 149 [in Ukrainian]

14. Savchyn M.V. (1997). Psykholohichni osnovy rozvytku vidpovidalnoi povedinky osobystosti: Dys... d-ra psykhol. nauk [Psychological bases of development of responsible personality behavior: Dis ... Dr. psych. Sciences]. Kyiv: Institute of Pedagogy and Psychology of Professional Education of the Academy of Pedagogical Sciences of Ukraine. P. 374. [in Ukrainian]

15. Topolnytska H. Yu. (2006). Zmina sotsialnykh ustanovok i vplyv kolektyvno-psykholohichnykh umov na formuvannia kultury mizhosobystisnykh vidnosyn $\mathrm{v}$ kursantskykh kolektyvakh [Changing social attitudes and the influence of collective-psychological conditions on the formation of a culture of interpersonal relations in cadets] // Zbirnyk naukovykh prats № 35. Chast. II [Collection of scientific works No. 35. Part. II]. Khmelnytskyi: Vyd-vo Natsionalnoi akademii DPSU [Published by the National Academy of the SBGS of Ukraine]. P. 134. [in Ukrainian]

16. Topolnytska H.Iu. (2011). Psykholohichni aspekty bazovykh tsinnostei moralnoi povedinky ofitsera-prykordonnyka [Psychological Aspects of Basic Values of Moral Behavior of Border Guard Officer] // Visnyk Natsionalnoi akademii Derzhavnoi prykordonnoi sluzhby Ukrainy : elektron. nauk. fakh. vyd. / hol. red. Hriaznov I. $O$ [Bulletin of the National Academy of State Border Guard Service of Ukraine: electronic issue. Ed. 
Hriaznov I.O.]. Vol. 5. URL: http://www.nbuv.gov.ua/e-journals/ Vnadps/2011_5/11tgupop.pdf_[in Ukrainian]

17. Yahupov V.V. (2000). Upravlinski funktsii ofitsera ta yikh pedahohichnyi zmist [The managerial functions of the officer and their pedagogical content] // Visnyk AU pry Prezydenti Ukrainy [Bulletin of the AU under the President of Ukraine]. Vyd-vo UADU. Vol. 2. P. 307. [in Ukrainian]

18. Yahupov V.V. (2004). Viiskova psykholohiia: Pidruchnyk [Military Psychology: Textbook]. Kyiv: Tandem. P. 156. [in Ukrainian]

19. Yadov V.Ya. (2000). Dispozitsionnaia kontseptsiia lichnosti [Dispositional concept of personality] // Sotsialnaia psikhologiia v trudakh otechestvennykh psikhologov [Social psychology in the works of domestic psychologists]. St. Petersburg. 512 p. [in Russian]

\section{Information about the author: \\ Halyna Topolnytska,}

Candidate of Psychological Sciences, Associate Professor,

Associate Professor in the Department of Psychology,

Moral and Psychological Support

The Bohdan Khmelnytskyi National Academy

of State Border Guard Service of Ukraine

46, Shevchenko St., Khmelnytskyi, Ukraine, 29003

ORCIDID: orcid.org/0000-0001-8316-0859

topgalina@i.ua 


\section{SOCIO-PSYCHOLOGICAL TRAINING AS AN EFFECTIVE METHOD FOR FORMING COMMUNICATIVE SKILLS OF BORDER GUARD CADETS}

\section{Valentyn Demskyi}

\section{INTRODUCTION}

The specificity of the future profession makes increasing moral demands on the border guard officer. These requirements act as a generally pedagogical idea, which should be based on wisdom, kindness, tact, ambition, demandingness, education, national consciousness of a person who has his own firm convictions, strong moral principles, able to courageously defend them, free and independent, person respected by subordinates and commanders. Interpersonal relationships, both objectively experienced and to a different degree conscious relationship between people, are closely linked to different types of social interactions. Interpersonal relationships within different forms of social relations are the direct realization of impersonal relationships in the activities of specific individuals in the acts of their communication and interaction ${ }^{1}$ (Vygotskij, 1956). Thus, the formation of communicative skills is a reflection of the socio-cultural situation in the country, in the State Border Guard Service of Ukraine and relates to the socio-cultural situation as a single with the general, and the statement of the problem of the culture of interpersonal relations of border guard officers from psychological point of view seems to be a psychological aspect.

Intercourse or communication, is one form of human interaction. As a process of information exchange that reflects the results of people's reflection of reality, communication is an integral part of their social existence and a means of forming and functioning of their consciousness, individual and social.

Thanks to communication there is organization of appropriate interaction of people in the course of joint activities, the transfer of experience, work and household skills, identification and satisfaction of spiritual needs.

Also, while communication with the objects of professional interaction, future border guard officers will decide on the job tasks, and it is therefore

${ }^{1}$ Vygotskij L.S. (1956). Izbrannye psihologicheskie issledovaniya [Selected Psychological Research]. Moscow. 341 p. [in Russian]. 
natural that their ability to communicate, make psychological contact and conduct including in conflict situations will ultimately depend on the overall effectiveness of the profession. This gives reason to consider that communicative qualities are the most important element in the structure of the border guard cadets professional training.

Communication is the process of establishing and maintaining purposeful, direct or indirect (by one or other means) contact between people, in one way or another, in a psychological connection ${ }^{2}$ (Koval, 2011). Making this contact allows you to either change the format of the joint activity by agreeing individual actions on these or other parameters, or, conversely, by allocating roles or functions to purposely influence the formation and change of the individual in the course of the activity.

Communication acts as a regulator of the relationship between objects of professional interaction. In addition, it should be borne in mind that the communicative activity of the border guard officer has a number of psychological characteristics. One of the most important psychological features of communication is its professional orientation, which is related to the need to contact also the persons who commited offense. A characteristic feature of the interpersonal interaction of border guard officers is its legal regularity it means compliance with the regulatory documents of the State Border Guard Service of Ukraine.

That is why today there is an urgent need to master the following communicative skills by border guard cadets:

quickly establish psychological contact with strangers;

exert a legitimate psychological influence on the objects of professional interaction;

overcome psychological barriers in communication;

perceive other people impartially.

\section{Methodological analysis of the nature and content of social and psychological trainings}

Psychology as a science examines the «patterns of development and functioning of the psyche as a special form of life.» "If the world of relationships is created by human activity, then what can be distinguished as their definite psychological» substance «? L. Vygotskij wrote. Such substances are categories that are used both in the cultural and psychological

${ }^{2}$ Koval S.B. (2011). Psykholohichni chynnyky rozvyvalnoi komunikatyvnoi sytuatsii u vyshchykh zakladakh osvity: Dys... kand. psykhol. nauk [Psychological factors of developmental communicative situation in higher education institutions: Dis ... Cand. psych. Sciences]. IvanoFrankivsk: Vasyl Stefanyk Carpathian University. 205 p. [in Ukrainian]. 
categorical apparatus, which are «intended» in the inner world and «represented» in human behavior, activity and interaction between people» ${ }^{3}$ [Vygotskij, 1956]. The unity of personal, social and activity factors in the psychological reflection incipience forms, its determination of psychological conditions, the active mediation of interpersonal relations in a social group, a systematic approach to the study of psychological processes and also theoretical provisions were formulated by military psychologists such as O. Safin, O. Timchenko, V. Yahupov and others. The dissertation researches of Y. Potapchuk, O. Makarevych, V. Kokhan, V. Nevmerzhytskyi, V. Semeniuk, T. Oliinyk, A. Trots, R. Belousova, O. Ivanova, H. Haidukevych and others were devoted to the scientific and practical analysis of the formation of communicative skills in military teams.

The theoretical concept is based on the following principles: systematicity, determinism, development, unity of consciousness and activity.

Modern humanitarian education requires the development of new active teaching methods, new programs and teaching aids developed on the basis of scientific research and practice of scientists - teachers in psychological disciplines. The teaching method is a rather complex, multifaceted and multidimensional pedagogical phenomenon that reflects the objective patterns, principles, goals, content and forms of learning ${ }^{4}$ (Yalom, 2010). This connection with other didactic categories is reciprocal: the principles, goals, content and forms of learning determine the method, but they cannot be implemented without taking into account the possibilities of their practical implementation.

Communication as an objective necessity in all forms of life arises at the same time with the formation of human society and the formation of man, but for a very long period it is not realized as a value, even in a purely practical, utilitarian sense ${ }^{5}$ (Puzikov, 2005). Inventing by man the personal sense of communication, the need in communication, in the process of which the individual asserts himself as a personality and realizes himself as a moral being, is the result of all subsequent history of mankind, in the thorny path of which the moral culture of communication, in some sense, emerges as a common form of practical activity of people. Given the current situation in Ukraine and directly in the State Border Guard Service, there is an urgent

\footnotetext{
${ }^{3}$ Vygotskij L.S. (1956). Izbrannye psihologicheskie issledovaniya [Selected Psychological Research]. Moscow. 341 p. [in Russian]

${ }^{4}$ Yalom I.A. (2010). Gruppovaya psihoterapiya: teoriya i praktika [Group psychotherapy: theory and practice]. 3rd ed. Moscow: Aprel Press, Psihoterapiya. 576 p. [in Russian]

${ }_{5}^{5}$ Puzikov V. G. (2005). Tekhnologiya vedeniya treninga [Technology for conducting a training]. St. Petersburg: Rech Publishing House. 224 p. [in Russian]
} 
need to find new non-traditional methods of study at a higher military educational establishment as extremely complex psycho-pedagogical and social-pedagogical entities.

The idea of training was first born among psychologists who, in 1946, trained teachers and social workers. The main task was to solve the problems connected with teaching and working in social groups. The founders of the training are K. Bens, L. Brandfort and K. Levin. In a year, the first training laboratories were established, in which social and psychological training groups were created. Later, an organization called the «National Training Laboratory» was established, under the auspices of which all training groups that had emerged and were already operating. American humanities scientist $\mathrm{K}$. Rodzhers called group training the grand revelation of our century. All methods of socio-psychological training are characterized, first, by the orientation on the wide use of the educational effect of group interaction ${ }^{6}$ (Rodzhers, 1994a), and secondly, these methods implement the principle of training group members through the use in the study elements of research.

Famous social psychologist K. Levin and his colleagues in the forties of the twentieth century started to create first training groups (T-groups) to increase the competence in communication with management staff. Psychologists have noticed that participants in small groups, when analyzing personal experiences, receive benefits and positive shifts, due to the fact that most people live and communicate in a society and in a group. K. Levin's main idea was to create situations in which T-group members could identify and change their attitudes, develop new behavior forms, and to do so, one must overcome authenticity and learn to see oneself as others see. The Tgroup was defined as a gathering of heterogeneous individuals who met to explore the interpersonal relationships of group dynamics engendered by interaction $^{7}$ (Rodzhers, 1994b].

Such groups actively trained managers, political leaders who wanted to effectively interact, manage, resolve conflicts in organizations, strengthen cohesion in groups. Sensitivity groups that emerged in 1954 were focused on explaining a person's vital values, enhancing his sense of self-identity.

Later in the 1970s. of the twentieth century German researcher M. Forverh introduced the concept of «social-psychological training» (SPT) in the training of industrial production managers. He noticed that during the

${ }^{6}$ Rodzhers K.R. (1994). Vzglyad na psihoterapiyu. Stanovlenie cheloveka [Look at Psychotherapy. The formation of man]. Transl. from English, ed. and foreword by Isenina B.I. Moscow: Publishing group «Progress», «Univers». 480 p. [in Russian]

7 Rodzhers K.R. (1994). Vzglyad na psihoterapiyu. Stanovlenie cheloveka [Look at Psychotherapy. The formation of man]. Transl. from English, ed. and foreword by Isenina B.I. Moscow: Publishing group «Progress», «Univers». 480 p. [in Russian] 
social-psychological training the formation of effective communication skills, due to the role-playing games with elements of dramatization, clearly occurs $^{8}$ (Forverg, 19).

Soviet psychologist L. Petrovskaya, the first in the 80 -ies of the twentieth century substantiated theoretical and methodological aspects of social and psychological training. She interpreted it as a means of developing competence in communication, and considered it as a means of influence aimed at developing knowledge, social attitudes, skills and experience in the field of interpersonal communication ${ }^{9}$ (Petrovskaya, 2007).

Therefore, training (from the train - to teach, educate, prepare, train) - is a method of active learning aimed at developing knowledge, skills and social attitudes. According to a practical psychologist O. Evtihov, «Group psychological training is a method of intentional change of the person, aimed at personal and professional development through acquisition, analysis and reassessment of personal life experience in the process of group interaction ${ }^{10}$ (Evtihov, 2005).

According to the author of the training of partner communication I. Slobodianiuk, social - psychological training of partner communication is a method of active social - psychological training and influence aimed at increasing the competence in communication ${ }^{11}$ (Slobodianiuk, 2010). V. Puzikov is of the opinion that conducting social-psychological training defined as «the field of practical psychology, focused on the usage of active methods of group psychological work for the development of competence in communication» should not be limited to training of communication, so training is an effective technology for teaching specific skills and abilities. A more important process is training, mastering and learning new skills based on group dynamics ${ }^{12}$ (Puzikov, 2005).

Non-traditional, search methods are quite productive in militaryprofessional training. They enable cadets not only to creatively acquire basic

${ }^{8}$ Forverg M. \& Alberg T. (1984). Harakteristika socialno-psihologicheskogo treninga povedeniya [Characteristics of socio-psychological behavior training]. / Psihologicheskij zhurnal [Psychological Journal]. Vol. 5. No. 4. P. 57-64. [in Russian]

9 Petrovskaya L.A. (1982). Teoreticheskie $i$ metodicheskie problemy social'nopsihologicheskogo treninga [Theoretical and methodological problems of socio-psychological training]. Moscow: Publishing House of MSU. [in Russian]

${ }^{10}$ Evtihov O. V. (2005). Praktika psihologicheskogo treninga [The practice of psychological training]. St. Petersburg: Rech Publishing House. 256 p. [in Russian]

11 Slobodianiuk I.A. (2010). Treninh partnerskoho spilkuvannia [Training of affiliate communication]. Kyiv: Navchalno-metod. tsentr "Konsortsium iz udoskonalennia menedzhment-osvity v Ukraini" [Educational and Methodological Center "Consortium on Improving Management Education in Ukraine"]. 48 p. [in Ukrainian]

${ }^{12}$ Puzikov V. G. (2005). Tekhnologiya vedeniya treninga [Technology for conducting a training]. St. Petersburg: Rech Publishing House. 224 p. [in Russian] 
knowledge, but also to master this knowledge at once in the context of their profession. These methods emphasize the development of learning potentials, proceed from the independent value of the search activity, put the teacher in the position of a partner for educational research, suggest the personal participation of all persons who take part in the educational process, mainly, to bring the ready knowledge, then in training the research participants themselves have to come to them. These methods suggest a kind of model training. Non-traditional methods include business, role, situational or imitation, operating games (trainings); the use of psychological tests that allow you to identify personality traits, tests to control knowledge; creative, active work with the concept apparatus; compilation of thematic crossword puzzles; choice of theme, route and writing of excursion scripts; conducting of various sociological researches, experiments, pedagogical practicum.

Traditional forms of training involve the acquisition of theoretical information by the cadet with its subsequent application, and then the opportunity to evaluate the usfulness of the received knowledge. Therefore, in traditional training, the teacher focuses mainly on the content of the training, and, using training technologies, he primarily facilitates reflection of the training participants acquired knowledge, which must be transformed through the intelligence, experience, emotional feelings of the subject of activity, which largely provides adequate feedback. In the course of the training, the participants, through feedback, show a lack of skills, so-called «white spots» of theoretical knowledge, as well as the inadequacy of existing attitudes and stereotypes ${ }^{13}$ (Sidorenko, 2004). This helps to correct inefficient behavior models and replace them with new ones that are more effective. A significant advantage of the training methodology is that it provides a unique opportunity to explore complex, emotionally relevant issues in a safe training environment, rather than in real life with its threats and risks. Training allows you to learn without worrying about the unpleasant consequences that can arise if you make the wrong decision.

Depending on the purpose and tasks that the training should solve, the following types can be distinguished:

1) socio-psychological training - aims at the development of communication skills, interpersonal relationships, the ability to establish and develop different types of relationships between people;

2) personal growth training - aims at self-improvement, resolving internal personal conflicts, contradictions, etc.;

13 Sidorenko E.V. (2004). Trening kommunikativnoj kompetentnosti $v$ delovom vzaimodejstvii [Training of communicative competence in business interaction]. St. Petersburg: Rech Publishing House. 208 p. [in Russian] 
3) thematic or social-educational training - is directed to the consideration of a specific topic, the content of which must be mastered, and the acquisition of the following skills and skills:

communication skills - they are developed throughout the training with the help of special games and exercises;

decision-making skills - for this purpose the trainer can use: «brainstorming»; discussion of one problem by the whole group; awareness and problem-solving games; decision algorithm etc;

skills to change behavior strategies that help a person to: flexibly respond to any situation, better adapt to the environment, quickly find a way out of difficult situations, realize their plans and achieve goals;

4) psycho-correction training - aims at the correction of mental processes, training of certain qualities and abilities personality;

5) psychotherapy training - aims to correct painful deviations of personal development (neurotic disorders, decompensation, character accentuations, etc.).

Each training consists of the same parts: introduction, main part and conclusion. The volume ratio of these parts in each case may be different. It depends on:

training goal - if it is only informational training, then the stage of practical skills formation can be very shortened;

type of target group - the younger the target group, the more used games-warm-up, games aimed at rallying the group, and the smaller the information block;

duration of training;

the level of preparedness of the group - if the group is well-informed, more time can be devoted to skills formation and discussion of social phenomena.

Nowadays, the practice of active social education has become second birth, since intensive methods of social and psychological training (business, role-playing games, etc.) were conducted many years ago. Thus, as early as the 1930s, about 15-20 variants of business games were used at individual enterprises and establishments. The reason that such work was terminated in our country is explained, first of all, by insufficient methodological base and weak connection of theory with practical problems.

\section{Basic procedures and principles of group operation}

The main content of communication in a training group is the sphere of human motives, the range of its needs. Through collective discussion, introspection, participants are able to understand the true meaning of their 
actions, see themselves from the outside, analyze their own experiences, subjective ideas.

Active social and psychological training can be seen as a new direction in the professional training of future border guards, which ensures the integration of the creative potential of management communication ${ }^{14}$ (Safin, 1997). The effectiveness of such a process is ensured by the group phenomenon. First of all, it's an opportunity to get feedback and support from people who share problems and experiences. In this group, people feel accepted and actively accept others, trust the group, and trust themselves. In a such group a participant can experiment with different communication styles, learn and practice different communication skills, feeling psychological comfort and security. Therefore, feeling support and control, the participant of the training group gets the opportunity to take possession for themselves certain styles of relations with different partners.

To start with, social and psychological training primarily develops the ability to maintain communication, psychologically stimulate the activity of a partner; maximum use the social and psychological characteristics of the communicative situation to realize its strategic line; to predict possible ways of development of the communicative situation in which communication develops; psychologically adjust to the emotional tone of partners' communication. I. V. Vachkov determines the specific features of social and psychological training. Observance of the principles of group work ${ }^{15}$ (Vachkov, 2007).

Focus on psychological assistance to group members in their selfdevelopment:

1. The presence of a more or less permanent group (7-15 people).

2. Specific extensional organization (isolated room, participants sit in a circle).

3. Emphasis on the relationships between the group, which are analyzed in the situation «here and now.»

4. Application of active methods of groupwork.

5. Objectivation of subjective feelings and emotions of group members regarding each other and what is happening in the group.

14 Safin O.D. (1997). Psykholohiia upravlinskoi diialnosti komandyra: Navchalnyi posibnyk [Psychology of commander's management activity: textbook]. Khmelnytskyi: PVU Academy Publishing House. 149 p. [in Ukrainian]

${ }^{15}$ Vachkov I.V. (2007). Psihologiya treningovoj raboty: soderzhatel'nye, organizacionnye $i$ metodicheskie aspekty vedeniya treningovoj gruppy [Psychology of training work: substantive, organizational and methodological aspects of conducting a training group]. Moscow: Eksmo. 416 p. [in Russian] 
6. Atmosphere of unselfconsciousness and freedom of communication between participants, formed climate of security.

Through the creation of an atmosphere of safety and tolerance in the group, which is neither criticized nor condemned, training participants find the opportunity to interact positively with others.

These specific features are otherwise fundamental to the organization of any training session, and the realization of these features is a specificity of the training work as a form of organization of activity ${ }^{16}$ (Mitina, 1997).

Education in social and psychological training is conditionally reduced to three levels: superficial, primary interpersonal openness, deep personal selfdisclosure.

At the surface level, there is orientation in the group, a sense of sympathy and dislike develops, surface interactions are observed in accordance with social and group norms.

At the level of primary interpersonal openness, protective barriers are reduced, there is partial self-disclosure, there is a willingness to accept criticism, similarity and difference of opinions, attitudes are established, and social sensitivity is increased.

At the level of deep personal self-disclosure, the mechanisms of selfdefense are excluded, sensitivity to the reactions of participants is exacerbated, deviations from the moral and ethical behavioral norms are revealed, the «I» concept and «I $»$ image of each participant are revealed.

Psychological content of the processes occurring in social and psychological training, is reduced to:

decrease in self-centered tendencies in the participants' behavior (decrease in verbal words, increase in number of non-verbal contacts, increase of feedback, increase of partner's understanding and understanding);

exacerbation of social sensitivity of participants (reduced communication thresholds, exacerbated sense of situation, group states and processes);

inhibition (weakens the effect of protective mechanisms, regulatory selfcontrol, a sense of safety and security, increases the naturalness of behavior, open expression of feelings, thoughts, relationships, activate personal potentials);

actualization of the creative potential of participants (the speed of generating ideas increases, the variability of reactions and behavior in general increases, the originality of problem-solving increases);

\footnotetext{
${ }^{16}$ Mitina L.M. (1997). Lichnostnoe i professionalnoe razvitie cheloveka v novyh socialnoekonomicheskih usloviyah [Personal and professional development of a person in new socioeconomic conditions]// Voprosy psihologii [Psychology Issues]. No. 4. P. 28-38. [in Russian].
} 
objectification of participants' behavior (the adequacy of self and selfesteem increases; the categorical expression is reduced and cognitive constructs are complicated);

developing self-sufficiency of the group (there is mutual support, a need for each other, a sense of closeness of the group);

increase of group work efficiency (mutual understanding between participants increases, time expenses for the organization of group work decrease $)^{17}$ (Yevdokymova, 2013).

It is also necessary to define methods of training work on the formation of communication skills and reflective abilities. The teaching method is a system of consistent interdependent actions between the teacher and the cadets, ensuring the assimilation of the content of education. It is characterized by three features: learning goals, ways of assimilating the content of learning, and the nature of the interaction of the learning subjects (teacher and cadet). Such methods are:

method of research creative position. During the training the participants of the group are aware of their personal resources, opportunities, features. The training program reproduces such situations that allow the group members to try and train new ways of behavior, to experiment with them;

a method of objectification (awareness) of behavior. The universal means of objectifying behavior is feedback. This method is aimed at the formation of skills, attitudes and attitudes, which increases the collectivist-oriented level of communicative interaction;

the method of confidentiality boils down to the recommendation not to advertise to outsiders the content of communication that develops in the course of work. This helps to create an atmosphere of trust, prevents possible moral harm, and the experience gained becomes the property of the group;

a method of role-playing. The participant of training sessions is constantly involved in playing a certain situation, performing the exercise, watching the behavior of other participants. A training participant may be involved in certain activities at any time in the group. At the same time, participating in the training and watching what is happening in the group is one of the most difficult tasks for the participants.

${ }^{17}$ Yevdokymova N. O. (2007). Sotsialno-psykholohichnyi suprovid stanovlennia fakhivtsia yak subiekta profesiinoi pravnychoi diialnosti [Socio-psychological support of becoming a specialist as a subject of professional legal activity] // Aktualni problemy navchannia ta vykhovannia liudei z osoblyvymy potrebamy: tezy dopovidei [Actual problems of education and education of people with special needs: abstracts]. Kyiv: University "Ukraina”. P. 238-240. [in Ukrainian]. 
Kinds of role-playing game: dating exercise, vicious circle, interview «I am a journalist», «Interview», game «Paper and pin», game «Situation «right-wrong». The main types of game method are:

psychotechnical games aimed at relieving mental stress, developing the ability to understand one's mental state, assessing it adequately and effectively managing oneself;

game methods of conflict resolution, the main task of which is to develop the cadets' abilities for reflection and empathy;

positional games (communication games), based on the concept of $\mathrm{E}$. Berne and allow cadets to occupy a position that is optimal for communication with a partner (ability to perceive).

Social and psychological trainings (adaptational, leadership, motivational, conflictological, antimanipulative) are aimed at accelerating the process of adaptation of cadets and border guards, formation of their motivational sphere and professional ideology, development of communicative skills in conflicts, confrontation of manipulative motives, confrontation with manipulatives, psychological culture, deepening the responsibility of participants for their own professional development ${ }^{18}$ (Romaniuk, 2004).

Structurally social and psychological training includes: problem statement, actualization of participants' personal experience, gaining of new experience through modeling of ways of actions, behaviors, formation of behavioral patterns, awareness and reflection of new experience in order to create a real environment, control the level of achievement, change of social and professional attitudes, stereotypes of behavior that allows to transfer the learned in training ways of action into reality.

\section{CONCLUSION}

Interpersonal relationships within various forms of social relations are the direct realization of impersonal relationships in the activities of specific individuals in the acts of their communication and interaction. Therefore, the formation of communicative skills is a reflection of the social and cultural situation in the country, in the State Border Guard of Ukraine and relates to the social and cultural situation as a single with the general, and posing a problem of culture of interpersonal relations of future officers.

Nowadays, the practice of active social education has become second birth, since intensive methods of social and psychological training (business,

18 Romaniuk L.V. (2004). Psykholohichni chynnyky rozvytku tsinnisnykh oriientatsii studentskoi molodi: Dys... kand. psykhol. nauk [Psychological factors of development of student youth value orientations: Dis ... Cand. psych. Sciences]. Kyiv: The Taras Shevchenko National University of Kyiv. 207 p. [in Ukrainian]. 
role-playing games, etc.) were conducted many years ago. Thus, as early as the 1930s, about 15-20 variants of business games were used at individual enterprises and colleges. The reason that such work was terminated in our country is explained, first of all, by insufficient methodological base and weak connection of theory with practical problems.

First of all, it is necessary to define methods of training work on the formation of communication skills and reflexive abilities. The teaching method is a system of consistent interdependent actions of the teacher and the cadets, ensuring the assimilation of the content of education. It is characterized by three features: learning goals, ways of assimilating the content of learning, and the nature of the interaction of the learning subjects (teacher and cadet) ${ }^{19}$ (Trots, 2013).

Such methods are:

method of research creative position. During the training the participants of the group are aware of their personal resources, opportunities, features. The training program reproduces such situations that allow the group members to try and train new behaviors, to experiment with them;

a method of objectification (awareness) of behavior.

A universal means of objectifying behavior is feedback. This method is aimed at the formation of skills, habits and attitudes, which increases the collectivisted and oriented level of communicative interaction;

the method of confidentiality boils down to the recommendation not to advertise to outsiders the content of communication that develops in the course of work. This helps to create an atmosphere of trust, prevents possible moral harm, and the experience gained becomes the property of the group;

a method of role-playing. The activity of a training group participant differs significantly from the activity of a person. The participant of training sessions is constantly involved in playing a certain situation, performing the exercise, watching the behavior of other participants.

The main purpose of social and psychological training (improving competence in communication) can be specified in tasks with different formulations, but necessarily related to the acquisition of knowledge, the formation of communication skills, the development of attitudes that determine behavior in communication, perceptual abilities of a person, with correction and development of the system of personality relations, because

19 Trots A.S. (2013). Dynamika samovdoskonalennia maibutnoho ofitsera u vyshchomu viiskovomu navchalnomu zakladi: Dys... kand. psykhol. nauk [Dynamics of self-improvement of future officer in higher military education: Dis ... Cand. psych. Sciences]. Kyiv: I.I. Mechnikov National University of Odesa. 193 p. [in Ukrainian]. 
personal identity is the background that paints in different colors of human action, all its verbal and non-verbal manifestations ${ }^{20}$ (Hryashcheva, 2006).

The main directions of formation of communicative skills in frontier cadets during the educational process are changes and correction of social attitudes and motivational sphere of personality, as well as the development of skills of competent communication. Prospects for further scientific research are to create a model of social and psychological training for the preparation of leading bodies of protection of the State Border of Ukraine.

\section{REFERENCES}

1. Vygotskij L.S. (1956). Izbrannye psihologicheskie issledovaniya [Selected Psychological Research]. Moscow. 341 p. [in Russian]

2. Vachkov I.V. \& Deryabo S.D. (2004). Okna $v$ mir treninga. Metodologicheskie osnovy subjektnogo podhoda $k$ gruppovoj rabote [Windows to the world of training. Methodological foundations of the subjective approach to group work]. Moscow: Rech. 272 p. [in Russian]

3. Vachkov I.V. (2007). Psihologiya treningovoj raboty: soderzhatel'nye, organizacionnye $i$ metodicheskie aspekty vedeniya treningovoj gruppy [Psychology of training work: substantive, organizational and methodological aspects of conducting a training group]. Moscow: Eksmo. 416 p. [in Russian]

4. Yevdokymova N.O. (2008). Rol adaptatsiinoho treninhu u formuvanni profesiinoi identychnosti studentiv- pravnykiv [The role of adaptation training in shaping the professional identity of law students]// Psihologicheskie tekhnologii $v$ ekstremalnyh vidah deyatelnosti: materialy IV Mezhdunarodnoj nauchno-prakticheskoj konferencii [Psychological technologies in extreme activities: materials of the IV International Scientific and Practical Conference]. Donetsk: Donetsk Law Institute of LHUVD. P. 160-162. [in Ukrainian]

5. Yevdokymova N.O. (2007). Sotsialno-psykholohichnyi suprovid stanovlennia fakhivtsia yak subiekta profesiinoi pravnychoi diialnosti [Socio-psychological support of becoming a specialist as a subject of professional legal activity]// Aktualni problemy navchannia ta vykhovannia liudei $z$ osoblyvymy potrebamy: tezy dopovidei [Actual problems of education and education of people with special needs: abstracts]. Kyiv: University "Ukraina”. P. 238-240. [in Ukrainian]

${ }^{20}$ Hryashcheva N. Yu. (2006). Psihogimnastika v treninge [Psycho-gymnastics in training]. Rech and Institut Treninga Publishing House. 256 p. [in Russian]. 
6. Evtihov O. V. (2005). Praktika psihologicheskogo treninga [The practice of psychological training]. St. Petersburg: Rech Publishing House. 256 p. [in Russian]

7. Koval S.B. (2011). Psykholohichni chynnyky rozvyvalnoi komunikatyvnoi sytuatsii u vyshchykh zakladakh osvity: Dys... kand. psykhol. nauk [Psychological factors of developmental communicative situation in higher education institutions: Dis ... Cand. psych. Sciences]. IvanoFrankivsk: Vasyl Stefanyk Carpathian University. 205 p. [in Ukrainian]

8. Mitina L.M. (1997). Lichnostnoe i professionalnoe razvitie cheloveka $\mathrm{v}$ novyh socialno-ekonomicheskih usloviyah [Personal and professional development of a person in new socio-economic conditions]// Voprosy psihologii [Psychology Issues]. No. 4. P.28-38. [in Russian]

9. Oliinyk T.I. (2001). Osobystisni chynnyky optymizatsii protsesu pidhotovky kursantiv do viiskovo-profesiinoi diialnosti: Dys... kand. psykhol. nauk [Personal factors of optimization of the process of preparation of cadets for military-professional activity: Dis ... Cand. psych. Sciences]. Kyiv: The H.S. Kostiuk Institute of Psychology of APS of Ukraine. 247 p. [in Ukrainian]

10. Petrovskaya L.A. (1982). Teoreticheskie i metodicheskie problemy social'no-psihologicheskogo treninga [Theoretical and methodological problems of socio-psychological training]. Moscow: Publishing House of MSU. [in Russian]

11. Puzikov V.G. (2005). Tekhnologiya vedeniya treninga [Technology for conducting a training]. St. Petersburg: Rech Publishing House. 224 p. [in Russian]

12. Rodzhers K.R. (1994). Vzglyad na psihoterapiyu. Stanovlenie cheloveka [Look at Psychotherapy. The formation of man]. Transl. from English, ed. and foreword by Isenina B.I. Moscow: Publishing group «Progress», «Univers». 480 p. [in Russian]

13. Romaniuk L.V. (2004). Psykholohichni chynnyky rozvytku tsinnisnykh oriientatsii studentskoi molodi: Dys... kand. psykhol. nauk [Psychological factors of development of student youth value orientations: Dis ... Cand. psych. Sciences]. Kyiv: The Taras Shevchenko National University of Kyiv. 207 p. [in Ukrainian]

14. Safin O.D. (1997). Psykholohiia upravlinskoi diialnosti komandyra: Navchalnyi posibnyk [Psychology of commander's management activity: textbook]. Khmelnytskyi: PVU Academy Publishing House. 149 p. [in Ukrainian]

15. Sidorenko E.V. (2004). Trening kommunikativnoj kompetentnosti $v$ delovom vzaimodejstvii [Training of communicative competence in business interaction]. St. Petersburg: Rech Publishing House. 208 p. [in Russian] 
16. Slobodianiuk I.A. (2010). Treninh partnerskoho spilkuvannia [Training of affiliate communication]. Kyiv: Navchalno-metod. tsentr "Konsortsium iz udoskonalennia menedzhment-osvity v Ukraini" [Educational and Methodological Center "Consortium on Improving Management Education in Ukraine"]. 48 p. [in Ukrainian]

17. Trots A.S. (2013). Dynamika samovdoskonalennia maibutnoho ofitsera u vyshchomи viiskovomu navchalnomи zakladi: Dys... kand. psykhol. nauk [Dynamics of self-improvement of future officer in higher military education: Dis ... Cand. psych. Sciences]. Kyiv: I.I. Mechnikov National University of Odesa. 193 p. [in Ukrainian]

18. Forverg M. \& Alberg T. (1984). Harakteristika socialnopsihologicheskogo treninga povedeniya [Characteristics of sociopsychological behavior training]. I Psihologicheskij zhurnal [Psychological Journal]. Vol 5. No. 4. P. 57-64. [in Russian]

19. Hryashcheva N. Yu. (2006). Psihogimnastika v treninge [Psychogymnastics in training]. Rech and Institut Treninga Publishing House. 256 p. [in Russian]

20. Yalom I.A. (2010). Gruppovaya psihoterapiya: teoriya i praktika [Group psychotherapy: theory and practice]. 3rd ed. Moscow: Aprel Press, Psihoterapiya. 576 p. [in Russian]

\section{Information about the author: Valentyn Demskyi,} Head of Psyhology and Moral and Psyhological Support Department, Bohdan Khmelnytskyi National Academy of the State Border Guard Service of Ukraine, 46 Shevchenko str., Khmelnytskyi, Ukraine, 29000

ORCID ID: orcid.org/0000-0003-4777-9392 


\section{THE ROLE AND PLACE OF FOREIGN LANGUAGE COMMUNICATIVE COMPETENCE IN THE FORMATION OF PROFESSIONAL COMMUNICATIVE ACTIVITY}

\section{Kateryna Oleksandrenko}

\section{INTRODUCTION}

This chapter considers the problems of developing of foreign language communicative competence of future specialists in international relations which has become an integral part of their professional communicative activity.

A significant expansion of intercultural interaction in all spheres of life of modern man actualizes the complex problems associated with foreign language education in general and the improvement of professional training of students of higher educational institutions in particular. In the modern Ukrainian system of higher education there are contradictions between the system of teaching foreign languages and level of requirements to the professional communicative activity of the future specialists, the absence and need for the elaboration of psychological and pedagogical concept of development of foreign language communicative competence of future specialists of international relations.

It is important to define the role and place of foreign language communicative competence in the formation of professional communicative activity which is a necessary condition for training specialists who know foreign languages and are able to get in touch with the representatives of other cultures.

\section{The concept of competence in psychological and linguistics studies}

Underlying that competences are some internal, hidden psychological new formations (knowledge, attitudes, behavior, values and relationships and so on), which later identified in the competencies, I. O. Zymnyaya ${ }^{1}$ highlights the following key competences: competence relating to the person as personality, subject of activity, communication; competence relating to social interaction and social spheres and competences concerning human activities. From these positions, she has delineated three main groups of

1 Zymnyaya, I.O. (1983). Kluchevyje competentsii - novaya paradigm rezultata obrazovaniya [The key competences as a new paradigm of the result in education]. Vyssheye obrazovaniye segodnya - Higher education today. 5, 34-42 [in Russian]. 
competencies: relating to oneself as personality, as the subject of life ; those that relate to human interaction with other people and competence relating to human activities, manifested in all its types and forms. The enumarated competencies, manifesting in behavior and activity of man, become his personal qualities, features. Accordingly, they become the competencies that are characterized by motivational and sence-bearing, relative, regulatory components, along with knowledge and experience N. Chomsky ${ }^{2}$ and W. Hutmacher ${ }^{3}$ emphasize the practical side of foreign language communicative competence. Researches conducted by N.I. Kuzmina ${ }^{4}$, A. A. Bodaliov ${ }^{5}$ became the basis for the determination of readiness for professional foreign language communicative activity as an integral personal phenomenon that implies a certain level of knowledge of a foreign language, linguisticcultural orientations and communicative skills, that is, the components of foreign language communicative competence.

Despite the high frequency of usage in modern scientific literature, the categories «communicative competence» and «communicative language competence» have not been defined yet and possess some inherent vagueness in definitions resulting in ambiguity of the conceptual field. The above mentioned statement is confirmed by the results of the analysis of a number of scientific research works, dictionaries and encyclopedias. The definition does not give a clear and unambiguous understanding of the nature of foreign language communicative competence as a personal phenomenon and mechanism of its formation.

To formulate the essential characteristics of foreign language communicative competence, it is necessary to define its place concerning the other types of competences, to consider the main functions and qualities of personality that somehow determine the development of this personal phenomenon or define them. The approach to defining the role of communicative competence in the formation of professional communicative activities based on the personal qualities, seems to be more accurate and thus it relates to humanistic values.

\footnotetext{
${ }^{2}$ Chomsky, N. (1965). Aspects of the theory of syntax. Cambridge, Massachusetts : MIT Press.

${ }^{3}$ Hutmacher, W. (1997). Key competencies for Europe. Report of the Symposium Berne, Switzerland 27-30 March 1997. Council for Cultural Cooperation (CDCC) : Secondary Education for Europe. Strasburg.

4 Kuzmina,N. (1989). Professionalizm deyatelnosti prepodavatelya $i$ mastera proizvodstvennogo obucheniya [Professionalizm of teacher's and instructor's activity]. Moscow: Vysshaya shkola. [in Russian].

${ }^{5}$ Bodaliov, A. A. (1998). Vershina $v$ razvitii vzroslogo cheloveka: kharakteristiki $i$ usloviia dostizheniia. [Apex in the development of an adult: characteristics and conditions of achievement]. Moscow: Nauka. Publ. [in Russian]
} 


\section{Different approaches to the definition of communicative competence}

The developing of foreign language communicative competence is one of the main factors in the formation of professional communicative activities.

Communicative competence is regarded as a set of formed professional knowledge, communicative and organizational skills, abilities to self-control, empathy, culture, verbal and nonverbal interaction, which is necessary in training specialists of different profiles, especially in socionomic professions. Foreign language communicative competence is understood as the ability of finding verbal and non-verbal means which are adequate to the situations of interactions and ways of formation and formulation of thought in its generation and perception in native and non-native languages.

From the point of view of personal approach, foreign language communicative competence is understood as mainstreaming of foreign language competences as a basic skill and includes willingness to exercise competence ; the experience of realization of competence in standard and non-standard situations ; subject matter competence and the object of its application; emotional-volitional regulation of process and result of competence.

From the standpoint of the systemic-structural approach, communicative language competence is a system, which includes communicative and cognitive abilities, cognitive activity, motivation, creativity and willingness to communicate in a foreign language. When considering the problem of abilities we rely on theoretical insights and research results substantiated by B.G. Ananyev ${ }^{6}$, N. V. Kuzmina7, S. D. Maksymenko ${ }^{8}$, A. K. Markova S. L. Rubinstein ${ }^{10}$, B. M. Teplov ${ }^{11}$, V. D. Shadrikov ${ }^{12}$ etc.

A significant contribution to the development of the general theory of abilities was made by B.M. Teplov. Understanding abilities as individualpsychological characteristics that relate to successful performance of this or that activity, the scholar claimed that abilities are created in the activities.

\footnotetext{
${ }^{6}$ Ananyev, B.G. (2001). O problemakh sovremennogo chelovekoznaniya [On the problems of modern human studies]. St.Petersburgh: Piter.[in Russian]

${ }^{7}$ Kuzmina, N.V. (1993). Professionalizm pedagogicheskoi deyatelnosti [Professionalizm of educational activity]. Rybinsk: NITSRM [in Russian]

${ }^{8}$ Maksymenko, S.D. (2006). Heneza zdiisnennia osobystosti [Genesis of personality realization]. Kyiv: TOV «KMM» Publ. [in Ukrainian]

${ }^{9}$ Markova, A.K ( 1996) Psikhologiya professionalizma [Psychology of professionalism]. Moscow: Znaniye [in Russian]

${ }^{10}$ Rubinshtein, S. L. (1989). Printsip tvorcheskoi samodeyatelnosti [The principle of creative activity]. Voprosy filosofii - Problems of Philosophy. 4, 88-96 [in Russian]

11 Teplov, B.M. (2004) Psikhologiya $i$ psikhofiziologiya individualnykh razlichii [Psychology and psychophysiology of individual differences] Otv. red. M.G. Yaroshevskii . Moscow: Izdatelstvo MPCI [in Russian]

${ }^{12}$ Shadrikov, V.D. (1994). Deyatelnost $i$ sposobnosti [Activity and ability]. Moscow: Logos[in Russian]
} 
This idea is based on a general thesis about the manifestation and the formation of mental properties in activities.

In the structure of communicative and cognitive abilities it is possible to distinguish several groups. The first group contains phonetic, lexical, grammatical, stylistic abilities, it ensures the absorption of language, its theoretical study: knowledge of vocabulary, learning grammar rules, logicalgrammatical structures of foreign language speech. These abilities contribute to the knowledge of the language system «language competence». The second group includes abilities that are manifested in the implementation of speech and language in the process of development of foreign language speaking activity. These are the abilities of speaking, listening, reading and writing. The third group of abilities determines the sense of language and foreign language thinking.

Communicative and cognitive abilities are realized through communicative activity that involves the steps of generating and interpreting texts on the basis of productive (speaking and writing) and receptive (reading and listening) types of speech activity in a specific situation. This gave grounds to speak about the need to develop skills related to reading, listening, speaking and writing, which must be accompanied by communicative skills, verbal and non-verbal in nature. The language is considered, in some sense, as a medium of communication and the means, which must be motivated.

The actual foreign language communicative competence consists of abilities:

keep (maintain) conversation (correspondence): on everyday topic, political issues, professional topics, the countries of the target language;

to start (be engaged in conversation), to suspend, finish, change the course (subject) of the conversation, continue a conversation in a foreign language (that is, to control the conversation);

to substantiate own statements, to persuade and to stimulate by means of the foreign language, and to express own attitude to the problem under discussion: in writing, verbally (in a particular situation);

to formulate and ask questions in a foreign language in writing, orally, within the process of reading, during listening;

reply (respond) to the question (statement) of the interlocutor in a foreign language in connection with the message;

understand foreign-language text based on visualization, to extract the necessary information: in the course of reading, during listening;

understand foreign-language text without relying on the visualization: as you read, during listening, comprehension. 
Formation of readiness for professional communication activities is essential to the training of specialists in foreign language who are able to get in touch with the representatives of other cultures. A.V. Selezneva ${ }^{13}$ refers the state of readiness to self-development conditions, intellectual and volitional, as its leading components are the desire to achieve successful self-development, to develop creativity and confidence in his/her own acmeological abilities, which can be regarded as characteristics of mental and volitional process of decision-making and conscious control of behavior, activities and status during the implementation of the decision.

A state of readiness to self-development can be considered as a holistic manifestation of inner activity of the individual in overcoming the internal contradictions and creative implementation of plans and programmes of selfactualization.

The measure of readiness for self-development is defined by the general and acmeological knowledge, skills, abilities, improving mental processes, states and personality traits, responsibility for results in self-development. Readiness is characterized by different relationships among the designated targets (cognitive - knowledge of a foreign language, axiological linguistic-cultural orientation, active - communicative skills).

Considering the willingness of the student to professional communication activities as a synthesis of a number of indicators, we defined the characteristics of different levels of development for each of the indicators of readiness, which have become the criterial basis of the study of the phenomenon of readiness of students to professional communication activities. The first (cognitive) indicator was considered in the context of the study as a different level of mastering a foreign language. Having determined the second (axology) indicator of the willingness of the students to the professional communicative activity of linguistic-cultural orientation, we mean the theoretical justification of value orientations as personal formation of the subject that characterizes the attitude to the phenomena of reality.

The state of readiness to professional communication activity can be attributed to predominantly intellectual, volitional states as its leading components are the desire to solve communicative tasks successfully, to develop creativity and confidence in ones communicative abilities, which can be regarded as characteristics of mental and volitional process of decision-making and conscious governance of behavior, activities and personal state during the implementation of solutions.

13 Selezneva, Ye.V. (2002). Obshcheniye kak sreda dlya samorazvitiya lichnosti [Communication as a means for the self-development of personality]. Moscow: RAGS [in Russian] 
Solution of a variety of communicative tasks requires constant and conscious mobilization of all efforts, based on the adequate reflection of the communicative situations and the actualization of images of the structure of the future communication actions. The condition of readiness for professional communication activities is mainly a manifestation of individual psychological characteristics and established system of communicative skills. The formation of the state of readiness for professional communication activities means the formation of a system of motives, relationships, attitudes, storage of knowledge, and skills that provide the ability to perform ones own functions in the communication process effectively. The formation of the state of readiness to foreign language communication passes as the process of optimization, that is, it is brought into line with the conditions of professional communicative activities to achieve the best results within it.

Readiness to the development of foreign language communicative competence, which is the basis for the formation of professional communicative activities, involves a communicative competence, i.e. knowledge of the linguistic material, the possession of methods, techniques and means of actualization of this knowledge in a particular situation, the skills of listening, speaking, writing in a researched language. It also implies the ability to exercise mental and cognitive activity, independence and selforganization in the solution of communicative and cognitive tasks. It is obvious that different level of required knowledge system, skills and abilities, as well as a different degree of activity and independence of the personality determines the different degree of readiness to make independent decisions and exercise independent action.

Considering foreign language communicative competence as a system, within which there is communicative and cognitive abilities, cognitive activity, motivation, creativity and willingness to communication in a foreign language, let us highlight its basic functions. In scientific literature there is no clear solution to the question about the features of communicative competence. Since communicative competence is regarded by most authors as the ability of a participant of communication to coordinate his/her language activities with the actions of communication partners according to selected targets in a specific communicative situation, the main functions are considered to be communicative - information, regulatory - communicative and emotional - communicative. Information - communication function is disclosed in the processes of transmission and reception of information by the partners in dialogue. Regulatory - communicative function is evident in the impact on the behavior of partners in the process of communication. Emotional-communicative function greatly affects the emotional state of a person greatly. 


\section{The structure of foreign language communicative competence}

Analysis of the structure of foreign language communicative competence of personality as an integrative concept enables us to formulate its main functions: information, socialization, cognitive, interpretative, integrative. Information function is an exchange of messages, opinions, ideas, solutions, that occur between communicants. Information exchange can be done with the purpose of achieving some practical goals, for the solution any problem and with the purpose of communication process, maintaining relationships between people.

The function of socialization is the formation and development of cultural skills relationships between people. This function forms our opinions, worldview, and reactions to certain events, provides entry into the society and socio-cultural environment. Cognitive function contributes to the understanding and study of the world and aims at making personal sense of knowledge, norms as a critical factor of activity. The interpretative function serves for ensuring understanding of your partner in communication act, his or her intentions, attitudes, feelings, states. Various means of communication not only reflect the events of the surrounding reality, but also interpret them in accordance with a certain system of values and political orientations. Some foreign researchers define this property of communication as interpretation function, thereby emphasizing the importance of interpretation of information, screening and lighting facts from certain positions. At the same time, this feature is often used to transfer specific methods, activities, assessments, opinions, judgments, etc. Integrative function serves as a means of combining knowledge, skills and methods of educational-cognitive activity from different disciplines into a coherent system that extends the limits of the discipline «foreign language» without loss of its qualitative characteristics and indicates a high willingness and ability to selfunderstanding, self-regulation, self-realization, the ability to use inner psychological reserve in one's professional activities.

Thus, summarizing the results of determination of elements of component parts of foreign language communicative competence and its functions, one can suggest that "foreign language communicative competence" is an integrative dynamic structural-level quality of an individual, represented by a set of communicative and cognitive abilities, cognitive activity, motivation, creativity, willingness to communication by means of a foreign language aimed at improving the effectiveness of professional communication activities.

The model of foreign language communicative competence is considered as a benchmark that simulates the structure and function of the system "society - personality - activity", and as the interpretation of the object of technologization of social, psychological, technological reality. Getting started with building a theoretical model of foreign language communicative 
competence, it is necessary to consider that foreign language communicative competence is manifested intersubject interaction. In this regard, the theoretical model should reflect the essential characteristics due to intersubject patterns of interaction based on the feedback mechanism, which changes under the influence of peculiarities of professional activity of a future specialist and social environment in which this interaction is happening and will happen.

While building the model of the development of foreign language communicative competence one can highlight the structural and functional aspects. The first of these is associated with the reflection of the systemic interrelationships of the essential characteristics of foreign language communicative competence, the second one is presupposed by the processes of intersubjective interaction in which it is implemented.

The structural and functional elements of the same system are inextricably linked. The recognition of this connection is the basis of structural-functional analysis, the principles of which are well established, particularly in studies of social phenomena and processes. The latter represent structurally dismembered integrity, in which each component element has a specific functional purpose. Minding it is very useful when modeling complex processes, especially those that are of social nature. Foreign language communicative competence is one of them. That is why along with structural and functional models we used integrative, structuralfunctional models.

It is important to note that the activities for the development of foreign language communicative competence can occur spontaneously (which does not exclude its awareness and commitment) and on the basis of professionally developed strategies and technologies in the process of formation of future specialist in higher educational establishments under the guidance of teachers. In both cases, it is legitimate to raise the question about the efficiency of this activity, that is, the extent to which the result is justified by the spent time, financial resources and other expenditures. From this point of view when building a theoretical model of foreign language communicative competence, it is advisable to use acmeological approach, which does not contradict the socio-psychological approach but rather complements it.

Functional components of the pedagogical system elaborated by N.V. Kuzmina allowed A.A. Derkach and S.F. Shcherbak ${ }^{14}$, by generalizing this theoretical result, to allocate macro components such as the gnostic, design, structural, organizational and communication in the foreign language

14 Derkach, A.A., Shcherbak, S.F. (1991). Pedagogicheskaya evristika: iskusstvo ovladeniya inostrannym yazykom [Pedagogical heuristics: the art of mastering a foreign language]. Moscow: Pedagogica [in Russian] 
activities of future specialists. All these components are found in activities aiming at developing foreign language communicative competence. Gnostic component involves awareness of the tasks of mastering a foreign language and their correlation with his/her general professional training, activities associated with the process of search, retrieval, systematization, generalization and the accumulation of new knowledge in a foreign language and on issues that have for students personal meaning. Gnostic component includes a system of theoretical knowledge required for productive foreign activities of the future specialist, as well as their abilities to productive use.

The design component includes activities associated with forecasting and perspective planning of solutions to specific problems in a foreign language (reading, listening, writing, speaking, communication in specific situations, etc.) and selection of the most rational of them, as well as the ability to anticipate and to relate education and practice. The constructive component is characterized by action selection of information (both linguistic and thematic) and compositional structure of the text, and the ability to transform it into diagrams, tables, drawings, graphs, figures, and vice versa: to build the text based on them, as well as the ability to build and rebuild their actions (verbal and non-verbal in nature) in connection with a specific situation of communication. The constructive component of foreign language communicative competence provides regularity and manufacturability of competence, thereby increasing the performance of the activities of the future specialist as a whole, in addition to its natural character, and minimizing accidents/mistakes.

Communicative component includes actions for the management and maintenance of conversation by means of foreign language on the topics studied, establishing contacts and appropriate relationship with the interlocutor (or interlocutors), as well as the ability to extract information and share it, to respond to the interlocutor (his verbal and nonverbal behavior). Communication component of foreign language activities plays a special role because, being developed in intersubjective interaction, this activity involves a high level of foreign language communicative competence.

Organizational component determines the actions to implement the plan in time and space in accordance with the agreed principles, plans, rules, and contains the ability to act on the sample and without the sample, individually and in the team ( as a leader including). Organizational component of the foreign language activities provides a link between the ideal model of foreign language communicative competence and the actual system of action of a future specialist in intersubjective interaction.

In our research, where the principles of personal and personal-activity approach are interrelated, and where competence is considered as a personality trait, we consider foreign language communicative competence 
as a structural-level quality of personality which is realized through the activities and presented as a set of communicative and cognitive abilities, cognitive activity, motivation, creativity and readiness for foreign language communication.

Foreign language communicative competence of a future specialist is a system of his identity, which developes by itself and is expressed in the willingness and ability to act on the basis of foreign language knowledge in different situations, and in the context of professional communication activities including. We noted the essential characteristics of foreign language communicative competence in its totality are expressed in motivational target, projective-constructive, social-perceptual, operational and reflexive components (Fig. 1).

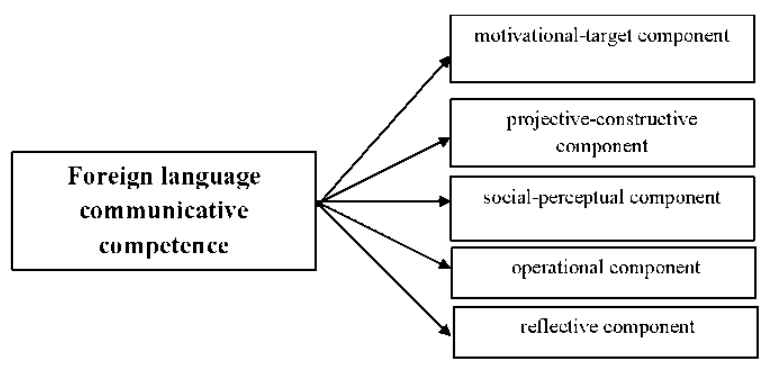

Motivational-target component provides the set of motives and internal conditions which determine, direct and regulate the process of foreign language communication. Projective-constructive component provides a practical analysis of the effectiveness of foreign language communication, forecasting the possible solutions to communication problems; updating the foreign language competence that is relevant to the purpose and situation of foreign language communication. Social-perceptual component ensures the situation/context of foreign language communication. Operational component ensures the implementation of operational plan and programme of foreign language communicative interaction through productive implementation of foreign language competencies. Reflexive component provides an adequate assessment of the deployment of the specific situation of foreign language communication and choice of possible variants of its development; it allows to understand the ways of self-improvement in the field of foreign language communication.

\section{CONCLUSIONS}

Summarizing the results of determination of elements of component parts of foreign language communicative competence, it is possible to assert that 
"foreign language communicative competence" is an integrative dynamic structural-level quality of the individual, represented by a set of communicative and cognitive abilities, cognitive activity, motivation, creativity, willingness to communication in a foreign language aimed at improving the effectiveness of professional communication activities. Analysis of the structure of foreign language communicative competence of the personality as an integrative concept allows us to formulate its main functions: information, socialization, cognitive, interpretative, integrative.

Foreign language communicative competence of a future specialist is a system of his/her identity, which expresses itself in the willingness and ability to act on the basis of foreign language knowledge in different situations, including the context of professional communication activities. The investigated essential characteristics of foreign language communicative competence in its totality are apparent in its motivational target, projectiveconstructive, social-perceptual, operational and reflexive components.

\section{SUMMARY}

Distinct and concrete presentation of the essence of foreign communicative competence as a newly established personal feature and mechanism of its development is formulated. Foreign communicative competence of the future specialist is the system of his/her personality, which may be described as self-developing and is expressed in readiness and ability to act on the basis of foreign language knowledge in different life situations the context of professional communicative activity including.

The essential features of foreign communicative competence are defined, which in their unity are expressed in its motivational - purposeful, projective - constructive, social - perceptive, operational and reflexive components, and encourage the formation of professional communicative activity of future specialists in international relations.

\section{REFERENCES}

1. Ananyev, B. G. (2001). O problemakh sovremennogo chelovekoznaniya [On the problems of modern human studies]. St.Petersburgh: Piter.[in Russian].

2. Bodaliov, A. A. (1998). Vershina v razvitii vzroslogo cheloveka: kharakteristiki $i$ usloviia dostizheniia. [Apex in the development of an adult: characteristics and conditions of achievement]. Moscow: Nauka. Publ. [in Russian]

3. Chomsky, N. (1965). Aspects of the theory of syntax. Cambridge, Massachusetts : MIT Press.

4. Derkach, A. A., Shcherbak, S.F. (1991). Pedagogicheskaya evristika: iskusstvo ovladeniya inostrannym yazykom [Pedagogical heuristics: the art of mastering a foreign language]. Moscow: Pedagogica [in Russian]. 
5. Hutmacher, W. (1997). Key competencies for Europe. Report of the Symposium Berne, Switzerland 27-30 March 1997. Council for Cultural Cooperation (CDCC) : Secondary Education for Europe. Strasburg.

6. Kuzmina, N. V. (1993). Professionalizm pedagogicheskoi deyatelnosti [Professionalizm of educational activity]. Rybinsk: NITSRM [in Russian].

7. Kuzmina N. V. (1989). Professionalizm deyatelnosti prepodavatelya $i$ mastera proizvodstvennogo obucheniya [Professionalizm of teacher's and instructor's activity]. Moscow: Vysshaya shkola. [in Russian].

8. Maksymenko, S. D. (2006). Heneza zdiisnennia osobystosti [Genesis of personality realization]. Kyiv: TOV «KMM» Publ. [in Ukrainian].

9. Markova, A. K. (1996) Psikhologiya professionalizma [Psychology of professionalism]. Moscow: Znaniye [in Russian].

10. Rubinshtein, S. L. (1989). Printsip tvorcheskoi samodeyatelnosti [The principle of creative activity]. Voprosy filosofii - Problems of Philosophy. 4, 88-96 [in Russian]

11. Selezneva, Ye. V. (2002). Obshcheniye kak sreda dlya samorazvitiya lichnosti [Communication as a means for the self-development of personality]. Moscow: RAGS [in Russian].

12. Teplov, B. M. (2004) Psikhologiya i psikhofiziologiya individualnykh razlichii [Psychology and psychophysiology of individual differences] Otv. red. M. G. Yaroshevskii . Moscow: Izdatelstvo MPCI [in Russian].

13. Shadrikov, V. D. (1994). Deyatelnost $i$ sposobnosti [Activity and ability]. Moscow: Logos [in Russian].

14. Zymnyaya, I. O. (1983). Kluchevyje competentsii - novaya paradigm rezultata obrazovaniya [The key competences as a new paradigm of the result in education]. Vyssheye obrazovaniye segodnya - Higher education today. 5, 34-42 [in Russian].

\author{
Information about the author: \\ Kateryna Oleksandrenko, \\ Doctor of Psychological Science, \\ Head of Foreign Languages Department \\ Khmelnytskyi National University, \\ 11 Instytutska Str., Khmelnytskyi, Ukraine, 29016 \\ orcid.org/0000-0001-9735-3715 \\ oleksandrenkok@gmail.com
}




\section{PSYCHOLOGICAL PECULIARITIES OF FOREIGN LANGUAGE COMPETENCE FORMATION IN THE MONOLOGIC SPEECH OF FUTURE PHILOLOGISTS}

\section{Hanna Bahrii}

\section{INTRODUCTION}

In the context of integration into a common educational space with the countries of the European Union, the language skills of the Ukrainian university graduates must also meet the common European requirements for proficiency in non-native languages. These include the ability to freely participate in any conversation and discussion, having a variety of idiomatic and colloquial means of speech.

The problem of foreign language competence formation in monologue speech remains relevant, since it needs consideration in the context of a competency-based approach that will allow it to be reconciled with others language and language competences - components of foreign language communicative competence, the formation of which is the purpose of learning foreign languages and cultures in educational institutions.

The problem of teaching monologue speech has a leading place in the scientific and methodological literature. The problem under study is considered by many methodologists such as B. Skalkin ${ }^{1}$, G. Rogova ${ }^{2}$, I. Zimnaya ${ }^{3}$, S. Passov ${ }^{4}$, M. Bukharkina ${ }^{5}$ and many others.

Psychological, pedagogical and methodological literature covers the experience of methodological organization of teaching monologic speech: a number of domestic and foreign studies devoted to the structure of speaking, general theoretical issues of teaching monologue (such as linguistic) and

${ }^{1}$ Skalkin V. L. (1983). Obucheniye monologicheskomu vyskazyvaniyu: posobiye [dlya uchiteley]. [Teaching monologic utterance: a manual [for teachers], (p. 55) [in Russian].

2 Rogova G.V., Rabinovich F.M., Sakharova T.Ye. (2000). Metodika obucheniya inostrannomu yazyku $v$ sredney shkole [Methods of teaching a foreign language in high school], (p. 49 - 50) [in Russian].

${ }^{3}$ Zimnyaya I.A. (2001). Lingvopsikhologiya rechevoy deyatel'nosti [Linguopsychology of speech activity], (p. 113). [in Russian].

${ }^{4}$ Passov S.I. (1988). Urok inostrannogo yazyka v sredney shkole [Foreign language lesson in high school], (p. 51-52) [in Russian].

5 Bukharkina M. YU. (2005). Metod proyektov v obuchenii angliyskomu yazyku [The project method in teaching English]. Inostrannyye yazyki $v$ shkole [Foreign languages at school], 3. p. $24-28$ [in Russian]. 
others, functional types of monological statements, various aspects of the methodology of monologue speech learning a foreign language in high school. Achieving a high level of development of a student of oral English ensures the readiness of future specialists to make real use of the acquired knowledge and skills in their professional activity. Therefore, proficiency in English is the key to the growth of professional skills of a modern specialist, in particular a future interpreter.

\section{The Peculiarities of Monologue Speech}

Scientists identify two types of oral activity: dialogue and monologue. The ability to build monologues is more complex than the ability to engage in dialogue. According to V. Skalkin ${ }^{6}$, monologue speech is contextual, unlike dialogue, which is most closely dependent on the situation. In dialogic language, the transmission of information is directed in two or more directions, each communicator's periods of speech activity are changed by periods of perception and processing of information, which contributes to facilitating communication.

Monologue speech, unlike dialogue speech, is characterized by the activity of only one communicator, which means "planning and programming not only one utterance or sentence, as, for example, in dialogue, but also the whole message". Note that monologue speech is a process of long, consistent, coherent presentation of a system of thought. Monologue language, which is the oral utterance of one person for the purpose of communicating information, influencing or inciting an action that has been considered earlier.

V. Skalkin understands the monologue speech as the process of communicatively motivated, logical, consistent and difficult, quite complete and correct in speaking verbally.

According to S. Passov, in the scientific context, the concept of "monologue speech"7 does not exist. He explains this contradiction by saying that when we say that no monologue exists, we mean that any communication (and we teach it) is dialogical in nature. There are always two parties involved: not only the speaker, but the listener. In general, this means that there are no statements that would had no orientation, purposefulness, there was no speaking in the void.

${ }^{6}$ Skalkin V.L. (1989). Obucheniye dialogicheskoy rechi [Teaching dialogic speech.], (p. 8-10) [in Russian].

${ }^{7}$ Passov S.I. (1988). Urok inostrannogo yazyka v sredney shkole [Foreign language lesson in high school], (p. 51-52) [in Russian] 
Scientist A. Alkhazishvili believes that monologue speech is of great importance in the context of a meaningful point of view of oral language ${ }^{8}$. $\mathrm{He}$ argues that monologue speech is less complex in terms of the use of speech samples than dialog.

Monologue speech has great compositional complexity, requires completeness of thought, adherence to grammatical rules, strict logic and consistency in teaching the content of the monologue. Therefore, teaching monologue speech is a great challenge for students.

Considering the studied and own experience of teaching a foreign language, we can distinguish the following difficulties that students face when working on a monologue in class:

- inability to work on different types of texts, which present the following types of information (story, description, reasoning);

- mastery of the means of expression of subject-emotional attitude to the object of expression;

- ignoring one of the principles of the communicant social portrait of the listener, the age of the addressee, his awareness of the issue, needs and interests;

- ignorance that listeners are at the same time spectators, so when speaking it is necessary to think not only about the content, but also how to speak;

- ignorance that speaking one's own monologue is productive but not reproductive;

- lack of integrity, coherence, reasoning and expression.

A number of scientists in the methodology highlights the following characteristics of monologue:

1) continuity (allows the speaker to express his or her thoughts fully), accessibility and clarity;

2) consistency and logic;

3) completeness and coherence of presentation of thoughts, development;

4) fullness of sentences, unidirectionality.

From a linguistic point of view, monologue is characterized by the full complexity of sentences and, as a rule, by a comprehensive presentation of thoughts ${ }^{9}$.

\footnotetext{
${ }^{8}$ Alkhazishvili A. A. (2000). Osnovy ovladeniya ustnoy inostrannoy rech'yu [Fundamentals of mastering oral foreign speech], p.72-73 [in Russian]

9 Symonenko T. V. (2006). Teoriia $i$ praktyka formuvannya profesiinoi movnokomunikatyvnoi kompetentsii studentiv filolohichnykh fakultetiv. [Theory and practice of formation of professional linguistic competence of students of philological faculties.], (p. 38-40) [in Ukrainian]
} 
According to the communicative purpose we can distinguish the following monological statements:

1. by the purpose of expression:

- monologue message;

- monologue-description;

- monologue-reasoning;

- a monologue-story;

- a monologue-persuasion.

2. by degree of readiness:

- prepared monologic language;

- unprepared monologue (own judgment, without support).

The substantive side of monologue speech must be combined with the expressive side that is created through linguistic means (use of words, phrases) and non-linguistic communicative means (mimics, gestures, intonations, pauses systems).

An important role in the teaching of monologue speech should be given to the creation of motives and conditions under which students show cognitive activity and feel the desire to use their knowledge, skills and abilities. But stimulating interest and maintaining high motivation in learning English is one of the problems of high school. P. Jacobson attributes such motivation to the motivation inherent in the process of activity itself ${ }^{10}$.

Thus, techniques, exercises, organization, creation of certain conditions for the organization of language exercises can influence the power of motivation. Therefore, it is important for the teacher to apply the optimal techniques of teaching monologue in English classes. Note that admission is specific actions and operations of the teacher, the purpose of which is to convey knowledge, to form skills and stimulate students' learning activities to solve problems in the learning process.

To overcome the above difficulties that students - future philologists may encounter in preparing a monologue, the teacher should master a variety of methodological techniques of teaching monologue.

One of the techniques of teaching monologue speech is the Project. I. Sokol notes that "the project is an implementation of self-planned work in which the monologue is organically combined in an intellectual-emotional context with other activities" $" 11$.

\footnotetext{
${ }^{10}$ Yakobson P.M. (1969). Problema motivatsii v psikhologii povedeniya cheloveka. [The problem of motivation in the psychology of human behavior] [in Russian].

11 Sokol I.A. (2008). Proyekt kak metod realizatsii kommunikativnogo podkhoda $v$ obuchenii inostrannomu yazyku [Project as a method of implementing a communicative approach in teaching a foreign language]. Inostrannyye yazyki $v$ shkole. [Foreign languages at school], 1, (p. 16-21) [in Russian].
} 
Many researchers note that the monologue is a form of oral communication that has a three-level structure. This structure includes: the first stimulating motivational phase, in which the speaker knows only the general subject or topic of the utterance and form of interaction with the listener; the second analytic-synthetic phase is the phase of thought formation by the means of language, characterized by logical consistency and syntactic correctness of speech expression; and the final third is the executive phase, which is responsible for the pronunciation and intonation of the monologue.

Bukharkina notes that the phases of the monologue and the stages of work on the project of expression are similar ${ }^{12}$. The project activity includes the following steps problem selection and formulation of a specific project theme; collection and processing of information; summarizing and presenting a new project.

Therefore, it is possible to outline the stages of work on the project as receiving the training of monologue. The first stage is the beginning and planning. The goal of this phase is that the teacher motivates students future philologists to achieve the result and explains the purpose. The second stage of the work is the formation and formulation of the monologue. At this stage that students encounter difficulties: what and how to pronounce in English, since they do not yet have the structure of expression. To do this, the teacher must be offered students visual support that helps to build a monologue (introduction, main part, conclusion) and focus efforts on mastering active vocabulary on the topic.

Another method of teaching monologue speech is Presentation - a presentation or verbal expression on a specific problem ${ }^{13}$. The features of this technique are depth of content, comprehensive expression, a clear organization, characterized by linguistic and information complexity and has an effective impact on the audience. For example, a presentation may reflect the results of a problem, or summarize research findings.

The goals of the presentation include: a detailed presentation of information, expression and presentation of one's vision, argumentation of points of view, beliefs.

Oral speech implies that the learner is able to interact with the audience. Presentation has the following structure: 1) a short presentation containing

${ }^{12}$ Bukharkina M.YU. (2005). Metod proyektov v obuchenii angliyskomu yazyku [The project method in teaching English]. Inostrannyye yazyki $v$ shkole [Foreign languages at school], 3. p. 24 - 28 [in Russian].

13 Bogdanova S. S. (1988). Logiko-kommunikativnyye programmy pri obuchenii monologicheskomu vyskazyvaniyu [Logic-communicative programs in teaching monologic utterance], 5, p. 35-43 [in Russian] 
the main idea and goal setting; 2) detailed presentation of information, development of the main idea, its justification, clarification; 3) arguments and conclusions; 4) engaging in discussion.

Communicative techniques for teaching monologue speech of students future philologists can also be referred to as the techniques of creating semantic associations (word associations): brainstorming, mind-mapping, the main task of which is generating ideas. In the course of their implementation, students are interested in finding bright, original, metaphorical analogies. A semantic association may be motivated by a keyword or concept, theme, or visual image that is associated with a broad semantic notion.

Brainstorming and mind-mapping allow students - future philologists to stimulate speech and thinking activity, actualize the speech experience, enrich the vocabulary. For example, when drafting a semantic map, students are encouraged to construct their own monologue statements that will be addressed to a specific audience.

\section{Factors of Formation of Students-Philologists Competence in Monologic Speech}

Increasing scientific interest in the humanization of higher education is due to many factors ${ }^{14}$. That is why the current stage of education development is characterized by the desire to reveal the theoretical foundations of its humanization, to systematically and organically integrate the formation of linguistic cultural competence in the process of professional formation of the personality of the future philologist.

In our opinion, communicative competence should be considered as a person's ability to understand and reproduce a foreign language not only at the level of phonological, lexico-grammatical knowledge and language skills, but also in accordance with the various goals and specifics of the communication situation.

We believe that from these points of view, it is not enough for speech communication to know only the language system at all its levels, to have rules for the generation of sentences designed according to grammatical norms, but it is also necessary to exercise its influence on the interlocutor in accordance with the task and situation of communication to use speech utterances.

${ }^{14}$ Tarnopolskyi O.B., Kozhushko S.P. (2008). Metodyka navchannya studentiv vyshchykh navchalnykh zakladiv pysma anhliyskoyu movoyu [Methods of teaching students of higher educational establishments writing in English], (p. 87-88) [in Ukrainian] 
Students - future philologists may not be ready for a monologue (unwilling to speak) or ashamed to speak, afraid to make a mistake, and thus criticize teachers and students. In this case, the teacher should remove the psychological barriers: to create a friendly atmosphere in the classroom, not to allow students to criticize sharply each other, to motivate students to produce monologues, interested in their topic, a problem that is familiar to them, known from their life experience.

Students - future philologists sometimes lack the vocabulary and speech tools to construct a monologue. To solve this problem, it is necessary to create a sufficient level of support for a meaningful, linguistic and speech plan. This means that development of monologue speech skills should be based on the already formed phonetic, lexical and grammatical skills within the suggested topic. Students should be able to use intonation and grammar correctly, logically design their speech through various means of communication $^{15}$. The substantive and linguistic value of the exercises is of great importance. The tasks offered to students should correspond to the real information stock of the students. Taking into account cross-curricular relationships can make it easier to solve the practical problems of mastering monologue. Different verbal and non-verbal supports can greatly help.

Sometimes a student cannot understand the speech task of creating a monologue. To overcome these difficulties, the teacher needs to know in advance what type of monologue he wants to get from the student, create a speech situation, clearly and concisely formulate the speech instruction, and prepare the necessary supports if necessary.

Consequently, we define communicative competence as an individual dynamic category that reflects the unity of language and personality.

Purposeful work on the formation of communicative competence was understood by us as a holistic process based on the coordination of its leading components: targeted, one that reflects the requirements of simultaneous participation of all students in the performance of individual tasks; meaningful, based on the selection of tasks that contribute to the successful formation of communicative competence; technological, defining conditions, methods and means of forming communicative competence; evaluation and effectiveness, based on the design of diagnostic methods for determining the formation of communicative competence.

15 Levchyk N. S., (2015). Formuvannya anhlomovnoyi audytyvnoyi kompetentnosti pershokursnykiv - maybutnikh uchyteliv anhliys'koyi movy [Formation of English-speaking auditory competence of freshmen - future English teachers]. Seriya: Pedahohichna: nauk. zapysky. Linhvodydaktyka [Series: Pedagogical: scientific notes. Linguistics.], 3. (p. 80-86) [in Ukrainian] 
On the basis of the identified leading components of students' communicative competence, we have developed a communicative and project-based method of forming the communicative competence of students of philological specialties.

The purpose of the practical English language course for students of philological specialties is the purpose of forming communicative competence in English speaking ${ }^{16}$ (in oral and written forms with actualization on a professional component), that is, a practical vocational oriented mastery of students in English speech, reading, listening, writing).

In our opinion, special attention should be paid to the implementation of professional and socio-cultural components (development of reading skills, abstracting and annotation of texts in the specialty and country studies, monologic and dialogical expression in the professional field of communication), so students - future philologists should:

- read authentic English literature on a specialty and socio-cultural subjects for obtaining information and its use in the further professional activity;

- abstract and annotate scientific literature in the specialty;

- participate in professional communication in English;

- have a structure of the document science of the country of the language being studied.

When organizing the learning process in order to form the communicative competence of students-philologists, the teacher should take into account the following factors in the development of educational activities ${ }^{17}$ :

- teaching a short translation of the content of the read or heard text in English (Ukrainian), as well as the preparation of annotations and short essays should be carried out in the course of performing a number of special exercises;

- phonetics and grammar are presented not as a set of rules for study, but as a language material, in the process of working on which the student's language skills and abilities are formed;

- mastery of lexical material occurs in the course of work on the texts of textbooks, manuals, humanities and original literature in the specialty;

- reading texts at all levels of study use authentic, compositional, structural and content-complete, different in volume and linguistic saturation

${ }^{16}$ Tal'skova N.D. (2004). Teoriya obucheniya inostrannym yazykam [ Theory of teaching foreign languages], (p. 224 - 225) [in Russian]

${ }_{17}$ Hymes, D. (1972). Hymes D. (1972). On communicate competence: Sociolinguistics. Harmondsworth, Middlesex: Penguin Education, (pp. 269-293) 
at different stages of learning. The average volume of classroom reading is 200-300 pages;

- phonetic minimum implies correct articulation of sounds, adherence to reading of all punctuation marks by pauses of different lengths, use of three basic tones (falling, lifting, falling-lifting);

- the lexical minimum is 2500 lexical units ( 1 module -800 lexical units, including the school minimum; 2 - 1200; $3.4-500)$. Composition of vocabulary: common, social and humanitarian, general scientific, terms of the subject of the science under study;

- the grammatical minimum includes normative grammar, as well as grammatical phenomena characteristic of the subject of the science under study and grammatical phenomena that present difficulties in learning the language;

- at the initial stage of learning systematized and generalized knowledge of the language acquired in secondary school, a phonetic, grammatical and lexical basis for the student's further work on the language is laid. Attention is paid to mastering the sounds and basic types of intonation and development of spoken language skills; the basics of listening to the English text are laid and the skills of reading socio-political and professional literature (for some purpose of adaptation) are formed;

- in the process of achieving the practical goal, general, cognitive and educational tasks are also realized. Studying English as a cultural and social phenomenon should contribute to the formation of students of general culture, the deepening of general linguistic knowledge. Therefore, it is recommended to use $40 \%$ of all the text material in the field of national and social sciences and humanities;

- topics for the development of oral language skills should be related to the life of students, their hometown, significant dates, the countries of languages being studied, as well as topical issues of social and humanitarian life in Ukraine and in the English-speaking countries.

We should also take into account the complex psychological nature of monologue speech, which influences the success of mastering this type of speech activity. Thus, during a monologue, the speaker should perform complex tasks: 1) to remember everything he said to the other party; 2) to present as a whole his statement; 3 ) to retain in memory the keywords and phrases predicted by the content of future utterances; 4) to formulate the meaning of the phrase, which should be expressed at the moment; 5) to build sentences from programmed components; 6) to overcome the interference of the mother tongue, which hinders the construction of a foreign language utterance correct from a lexical and grammatical point of view; 7) to listen to 
own speech, to control its normativity, if necessary to correct parts of the phrase that have already been spoken ${ }^{18}$. Thus, monologue speech is, first and foremost, an increased workload for operational and long-term memory, thinking and speech mechanisms of the individual.

It is possible to teach students to build a program of their own monologue utterances, overcoming these difficulties, by means of advanced communicative tasks in which the ultimate goals are clearly formulated, and the utterances are limited by instructions, specially created supports, and intelligently selected language material necessary for the implementation of languages ${ }^{19}$. The success of teaching monologue speech also depends on the individual age characteristics of students, the presence of motives for learning, attention, interest, the level of mastery of students general and special educational skills in learning a foreign language, that is, the level of educational and strategic competence.

The development of students' oral monologue speech should be carried out with the help of a specific methodological system, including the organization of training, which would contribute to the successful formation of monologue speech. Factors that positively influence the learning process are favorable learning conditions, effective subsystem of exercises for teaching monologue, the presence and rational use of all necessary teaching aids, various and optimal forms of students' work in classes, the appropriate structure of foreign language lessons.

\section{Technology of Formation of Speech Competence of Future Philologists in the Process of Studying Professional Disciplines}

The analysis of the state of speech competence was updated the need to find ways to increase the effectiveness of future philologists stydying in the context of modern social and educational needs. Such an instrument, in our opinion, could be the technology of forming the speech competence of future philologists in the process of studying professional disciplines, which is based on a set of sound pedagogical conditions as the initial factors of the effectiveness of the process under study.

${ }^{18}$ Martynova R.Iu. (2013). English for social teachers: navch. posibnyk dlia studentiv pedahohichnykh universytetiv. Odesa : vydavets Bukaiev Vadym Viktorovych [in Ukrainian]

${ }_{19}$ Zadorozhna, I. P., (2012). Zadorozhna I. P. (2012). Teoretyko-metodychni zasady orhanizatsii samostiynoi roboty maybutnikh uchyteliv $z$ ovolodinnya anhlomovnoyu komunikatyvnoyu kompetentsiey. [Theoretical and methodological foundations of the organization of independent work of future teachers to master English-speaking communicative competence], (p. 482) [in Ukrainian] 
Technology in the scientific literature is considered as an algorithm of the organization educational process containing the goals, content and methods of achievement planned results ${ }^{20}$.

Interesting, in our opinion, is the difference between educational and pedagogical technologies, given the level of innovation. So is educational technology reflect strategies in education by predicting its further development, design and planning of the educational environment. Pedagogically technology reproduces the tactics of educational transformation through reflection models of educational and / or management processes. That is, we are designing pedagogical technology that demonstrates tactics realization of pedagogical conditions of speech competence formation future foreign language teachers in the course of study of professional disciplines.

There are two types of speech forming technologies competence ${ }^{21}$ :

1) cognitive-oriented, modeled from language to speech ", reflect the rational-logical way of mastering the language and include grammatical, analytical, comparative methods;

2) communicative-oriented, based on a "speech-to-speech" model, reflect a situational way of mastering a language through natural (or close to natural) communication situations.

We have developed a technology for the formation of speech competence of future philologists in the process of study of professional disciplines is a communicative-oriented, purposeful, systematic pedagogical activity to harmonize the goals, forms, content, methods and learning outcomes.

This understanding of the technology of speech competence formation defines its structure: target, organizational, content, process and result components.

In general, we consider the process of organizing the speech competence of future educators as creating the conditions for the development and implementation of technology, which will ensure coherence and interconnection between technological components. That is, theoretically and empirically substantiated pedagogical conditions, being realized in the process of studying professional disciplines, provide a rational structure of pedagogical influence and educational interaction ${ }^{22}$.

20 Canal M. (1983). From communicative competence to communicative language pedagogy. Language and Communication. (pp. 2-27).

21 Hymes, D. (1972). On communicate competence: Sociolinguistics. Harmondsworth, Middlesex : Penguin Education, (pp. 269-293).

${ }^{22}$ Leont'yev A.A. (2003). Yazyk, rech', rechevaya deyatel'nost' [Language, speech, speech activity], (p. 62-63) [in Russian]. 
Inferring psychological and pedagogical conditions into a separate component of technology reflects the procedural approach to its design and implementation, substantiating the forms of organization of the process of study of professional disciplines (according to the above conditions: monitoring, case study, dialog teaching, training and production practices).

In addition, when characterizing psychological and pedagogical conditions, we define the connection of each condition with theoretical approaches in pedagogy and psychology, which allows us to fulfill the necessary requirements for the technological process of formation of speech competence. Specifically, the requirements are: conceptualisation as a support for pedagogical theories, systematicity as ensuring the interconnection and integrity of pedagogical transformations, controllability and reproducibility due to the ability to control the organization of psychological conditions for the study of professional disciplines. The specified requirements meet the criteria of adaptability.

The process of mastering the foreign language knowledge and skills of monologue is accompanied by the development of communicative abilities of those who learn a foreign language. Communicative abilities to monologue speech are the social and communicative abilities of the individual, which ensure the effective implementation and management of communication in monologue form. The communicative abilities, on the one hand, are the result of the students' activity in monologue speech, and on the other hand, determine the success of its implementation. Communicative abilities for monologue speech are the following ${ }^{23}$ :

- intrinsic motivational readiness (desire) to speak, a sense of need to say something, the speaker's ability to understand what he or she wants to say, or external motivational readiness as a response to a verbal stimulus (an interlocutor's response to a question, that is, a speech caused by a situation communication);

- the ability to organize his monologue, structure and conclude it;

- the ability of the speaker to navigate the situation, ie the ability to receive and correctly understand signals from the listener / listeners and external circumstances of the situation, the ability to change their expressions and behavior in accordance with these signals in order to achieve the greatest adequacy and effectiveness of monologue speech in terms of purpose and purpose intentions;

${ }^{23}$ Kabardov M. K., Artsishevskaya Ye.V. (1996). Tipy yazykovykh i kommunikativnykh sposobnostey $i$ kompetentsiy. [Types of linguistic and communicative abilities and competencies.], 1. (p.34 - 49) [in Russian] 
- the ability to remember what has been said before by the speaker, thereby ensuring the coherence of speech, its logic, the ability to express an opinion, to find in the long-term memory the language forms of expression needed and to combine them into coherent sentences and coherent text based on random access memory;

- the ability to understand, reflect on the content of one's monologue (subconsciously, in standard situations and conditions) and its linguistic form (consciously and semi-consciously, in non-standard (problematic) situations and conditions), the ability in normal quiet speaking, to correct and change said directly in the speech process;

- the ability to formulate expressions that satisfy the linguistic norm and usages, including the requirements regarding the linguistic form of expressions that exist in a given linguistic and cultural community;

- ability to focus attention not only and not so much on linguistic rules and norms, but on rules and norms of communication and behavior in it; adequate;

- the ability to use paralinguistic means to make their language more

- the ability to express oneself through monologue speech due to the need for self-affirmation, intrinsic high motivation (the process of speaking is gratifying), the ability to express oneself by means of a foreign language being studied, to express one's own thoughts, views, emotions, attitude to what it is about interesting to convince the listener etc;

- the ability to self-evaluate what is said through controlling one's own utterances, to compare what was actually said, with what was intended to be said, and with what impact the said has on the listener;

- the ability to control emotions, to fully adequately assess what is said, so as not to cause (due to strong emotions) to disrupt communication or to achieve a result exactly opposite to what was planned, etc.

In addition, communicative abilities also include general abilities for monologue speech, including those developed on the material of the mother tongue that underlie the personality's ability to produce verbal expressions ${ }^{24}$. These are language/speech abilities: the students' well-developed psychic processes related to monologue speech activity (attention, operative and long-term memory, logical, analytical, imaginative thinking, imagination, fantasy, speech mechanisms of speech), as well as motives, needs, interests, directions, feelings and emotions, experience in outlook, activity, willingness to overcome difficulties, communication skills, desire for self-

${ }^{24}$ Vol'fovs'ka T. O. (2001). Komunikatyvna kompetentnist molodi yak odna z peredumov dosyahnennya zhyttyevyi mety [Communicative competence of youth as one of the prerequisites for achieving a life goal]. Shliakh osvity [Path of education], 3. (p. 13-16) [in Ukrainian] 
expression in monologue speech and other abilities for intercultural monologic communication (communication skills, tolerance ness, the ability to interact socially with students/partners in communication, culture, communication, ability to adequately communicate with people of different national cultures).

Exercises for the development of foreign language monologue can be divided into preparatory and language. With their help, specific for monologue speaking skills are produced. Preparatory exercises are aimed at learning the components of monologue speech: the formation of phrases and their combination in accordance with the logic of presentation. At the same time you need to be able to justify the correctness of your statements, including in your language elements of reasoning, argumentation, etc. Language exercises are aimed at developing skills to consistently reveal a topic, translate text, make a description, a message, a story.

Exercises for teaching prepared monologic language of philological orientation include: reproducing coherent statements; drawing up a situation or story; description of the drawing; reproduction of situations; legend; transfer of information in several phrases; drawing up a plan for a listening story; presentation of dialogues in monologue form and the like. Exercises for teaching unprepared monologue speech: inventing a title and its justification; a description of the painting not related to the topic under study; substantiation of own judgment or relation to facts; evaluation of what has been heard or read; expressing one's own opinion; comment and discussion ${ }^{25}$.

In the process of teaching a monolingual monologue, it is possible to distinguish three stages of formation of monologic skills ${ }^{26}$ : Stage I - to teach students to combine the speech patterns of the phrase level into one unity; Phase II - to teach students to build expressions beyond phrase level; Stage III - to teach students to create monological expressions of the textual level of different functional-semantic types of speech.

One of the most important features of the monologic speech of a translator of philological orientation is its situationality, in fact, the external circumstances in which the communication takes place: place, time, personality of the partner(s), social roles of the interlocutors, etc.

Due to the constant development of international relations, organization of business trips, exchange of specialists, as well as participation in various

${ }^{25}$ Rogova G. V., Rabinovich F. M., Sakharova T. Ye. (2000). Metodika obucheniya inostrannomu yazyku $v$ sredney shkole. [Methods of teaching a foreign language in high school], (p. 49 - 50) [in Russian]

${ }^{26}$ Skalkin V. L. (1983). Obucheniye monologicheskomu vyskazyvaniyu: posobiye [dlya uchiteley]. [Teaching monologic utterance: a manual [for teachers]] (p. 55). [in Russian] 
competitions, meetings, conferences, olympiads, our country needs specialists who have not only qualitative knowledge in their professional sphere, but also possess sufficient English language skills that are able to represent Ukraine abroad well ${ }^{27}$.

Therefore, language skills are part of the philologist's professional competence.

The issue of determining the specificity of English monologic language of philological orientation is relevant in view of the issue of increasing the language activity of students of philological specialties in the process of learning a foreign language by professional direction ${ }^{28} 29$. The effectiveness and efficiency of this type of speech is determined by the theme of the sociopedagogical text and its content. The specificity of the monologue speech of the philologist-translator depends on the situations that arise in professional activity or communication.

\section{SUMMARY}

The article is devoted to the study of the peculiarities of teaching monologue speech of students in English classes at universities. Theoretical analysis of the research problem suggests that monolingual monologic communication is possible provided that the subjects of foreign language communication speak the language as a means of communication. Level of the effectiveness of the communication process is conditioned by the level of formation of the subject's foreign-language monologic communicative competence.

Competence is the persistent willingness and ability of a person to engage in any activity with the knowledge of the case. In our case, such activity is the foreign language communication of students in the process of learning a foreign language. Hence the definition of foreign language communicative competence as an integrative formation of personality, which has a complex structure and acts as an interaction and interpenetration of linguistic, socio-cultural and communicative competences, the level of

\footnotetext{
${ }^{27}$ Zimnyaya I.A. (2001). Lingvopsikhologiya rechevoy deyatel'nosti [Linguopsychology of speech activity] (p. 113). [in Russian]

${ }^{28}$ Tarlakovskaya Ye.A. (2009). Obucheniye studentov lingvisticheskogo vuza sposobam realizatsii funktsii vozdeystviya monologicheskoy rechi [Teaching students of a linguistic university how to implement the function of the impact of monologic speech.], (p. 23-24) [in Russian]

29 Zadorozhna, I. P., (2012). Zadorozhna I. P. (2012). Teoretyko-metodychni zasady orhanizatsii samostiynoi roboty maybutnikh uchyteliv $z$ ovolodinnya anhlomovnoyu komunikatyvnoyu kompetentsiey. [Theoretical and methodological foundations of the organization of independent work of future teachers to master English-speaking communicative competence], (p. 482) [in Ukrainian]
} 
formation of which allows the future specialist to effectively perform a foreign language, and thus interpersonal communication.

Our study theoretically establishes more effective methods of teaching and forming a foreign-language monologic communication competence of future philologists with the consideration of certain psychological peculiarities.

It should be said that foreign language competence provides a certain cultural level of oral and written speech and non-verbal speech behavior.

Formation of a monologic communicative competence in students of higher education institutions of different directions of preparation at the present stage of development of the world community should be considered as a mandatory component of general professional training. In order to ensure the effectiveness of the process of forming a foreign-language monologic communicative competence, it is advisable to develop new methodological approaches and determine the psychological and pedagogical conditions for their implementation.

\section{REFERENCES}

1. Alkhazishvili A. A. (2000). Osnovy ovladeniya ustnoy inostrannoy rech'yu [Fundamentals of mastering oral foreign speech], p. 72-73 [in Russian].

2. Bogdanova S. S. (1988). Logiko-kommunikativnyye programmy pri obuchenii monologicheskomu vyskazyvaniyu [Logic-communicative programs in teaching monologic utterance], 5, p. 35-43 [in Russian].

3. Bukharkina M. YU. (2005). Metod proyektov $v$ obuchenii angliyskomu yazyku [The project method in teaching English]. Inostrannyye yazyki v shkole [Foreign languages at school], 3. p. $24-28$ [in Russian].

4. Canal M. (1983). From communicative competence to communicative language pedagogy. Language and Communication. (p. 2-27).

5. Hymes D. (1972). On communicate competence: Sociolinguistics. Harmondsworth, Middlesex : Penguin Education, (p. 269-293).

6. Kabardov M. K., Artsishevskaya Ye.V. (1996). Tipy yazykovykh $i$ kommunikativnykh sposobnostey $i$ kompetentsiy. [Types of linguistic and communicative abilities and competencies.], 1. (p. 34 - 49) [in Russian].

7. Leont'yev A. A. (2003). Yazyk, rech', rechevaya deyatel'nost'. [Language, speech, speech activity]. (p. 62 - 63) [in Russian].

8. Levchyk N. S., (2015). Formuvannya anhlomovnoyi audytyvnoyi kompetentnosti pershokursnykiv - maybutnikh uchyteliv anhliys'koyi movy [Formation of English-speaking auditory competence of freshmen - future English teachers]. Seriya: Pedahohichna: nauk. zapysky. Linhvodydaktyka [Series: Pedagogical: scientific notes. Linguistics.], 3. (p. 80-86) [in Ukrainian]. 
9. Martynova R.Iu. (2013). English for social teachers: navch. posibnyk dlia studentiv pedahohichnykh universytetiv. Odesa : vydavets Bukaiev Vadym Viktorovych [in Ukrainian].

10. Passov S. I. (1988). Urok inostrannogo yazyka $v$ sredney shkole [Foreign language lesson in high school], (p. 51-52) [in Russian].

11. Rogova G. V., Rabinovich F. M., Sakharova T. Ye. (2000). Metodika obucheniya inostrannomu yazyku $v$ sredney shkole. [Methods of teaching a foreign language in high school]. (p. 49 - 50) [in Russian].

12. Skalkin V. L. (1983). Obucheniye monologicheskomu vyskazyvaniyu: posobiye [dlya uchiteley] [Teaching monologic utterance: a manual [for teachers]], (p. 55) [in Russian].

13. Skalkin V. L. (1989). Obucheniye dialogicheskoy rechi. [Teaching dialogue speech.], (p. 8-10) [in Russian].

14. Sokol I. A. (2008). Proyekt kak metod realizatsii kommunikativnogo podkhoda $v$ obuchenii inostrannomu yazyku [Project as a method of implementing a communicative approach in teaching a foreign language]. Inostrannyye yazyki $v$ shkole. [Foreign languages at school], 1, (p. $16-21)$ [in Russian].

15. Symonenko T. V. (2006). Teoriia i praktyka formuvannya profesiinoi movnokomunikatyvnoi kompetentsii studentiv filolohichnykh fakultetiv. [Theory and practice of formation of professional linguistic competence of students of philological faculties.], (p. 38-40) [in Ukrainian].

16. Tal'skova N. D. (2004). Teoriya obucheniya inostrannym yazykam [Theory of teaching foreign languages], (p. $224-225$ ) [in Russian].

17. Tarnopolskyi O. B., Kozhushko S. P. (2008). Metodyka navchannya studentiv vyshchykh navchalnykh zakladiv pysma anhliyskoyu movoyu [Methods of teaching students of higher educational establishments writing in English], (p. 87-88) [in Ukrainian].

18. Tarlakovskaya Ye. A. (2009). Obucheniye studentov lingvisticheskogo vuza sposobam realizatsii funktsii vozdeystviya monologicheskoy rechi [Teaching students of a linguistic university how to implement the function of the impact of monologic speech.], (p. 23-24) [in Russian].

19. Volfovska T. O. (2001). Komunikatyvna kompetentnist molodi yak odna $z$ peredumov dosyahnennya zhyttevoi mety [Communicative competence of youth as one of the prerequisites for achieving a life goal]. Shlyakh osvity [Path of education], 3, (p. 13-16) [in Ukrainian].

20. Yakobson P. M. (1969). Problema motivatsii $v$ psikhologii povedeniya cheloveka [The problem of motivation in the psychology of human behavior] [in Russian].

21.Zadorozhna I. P. (2012). Teoretyko-metodychni zasady orhanizatsii samostiynoi roboty maybutnikh uchyteliv $z$ ovolodinnya anhlomovnoyu 
komunikatyvnoyu kompetentsiey. [Theoretical and methodological foundations of the organization of independent work of future teachers to master English-speaking communicative competence], (p. 482) [in Ukrainian].

22.Zimnyaya I. A. (2001). Lingvopsikhologiya rechevoy deyatel'nosti [Linguopsychology of speech activity], (p. 113) [in Russian].

\section{Information about the author:}

Hanna Bahrii, Candidate of Sciences in Psychology, Associate Professor of the Translation Department, National Academy of the State Border Guard Service of Ukraine named after Bohdan Khmelnytskyi 46, Shevchenko str., Khmelnytskyi, 29003, Ukraine ORCID ID: orcid.org/0000-0003-0928-2940 bahrii_82@ukr.net 
Publishing house "Liha-Pres"

9 Kastelivka str., Lviv, 79012, Ukraine 44 Lubicka str., Toruń, 87-100, Poland

Printed by the publishing house "Liha-Pres"

Passed for printing: December 23, 2019.

A run of 150 copies. 